UNIVERSIDADE DE SÃO PAULO

HOSPITAL DE REABILITAÇÃO DE ANOMALIAS CRANIOFACIAIS

\title{
ASPECTOS PSICOSSOCIAIS E FAMILIARES DE INDIVÍDUOS COM E SEM DISTÚRBIOS DA COMUNICAÇÃO DECORRENTES DA FISSURA LABIOPALATINA.
}

\author{
REGINA CÉLIA MEIRA GARCIA \\ Dissertação apresentada ao Hospital de \\ Reabilitação de Anomalias Craniofaciais, da \\ Universidade de São Paulo, para a obtenção do \\ título de MESTRE em Ciências da Reabilitação. \\ Área de Concentração: Distúrbios da \\ Comunicação Humana
}

Bauru

2006 


\title{
UNIVERSIDADE DE SÃO PAULO \\ HOSPITAL DE REABILITAÇÃO DE ANOMALIAS CRANIOFACIAIS
}

\section{ASPECTOS PSICOSSOCIAIS E FAMILIARES DE INDIVÍDUOS COM E SEM DISTÚRBIOS DA COMUNICAÇÃO DECORRENTES DA FISSURA LABIOPALATINA.}

\author{
REGINA CÉLIA MEIRA GARCIA \\ Orientador: Profa. Dra. Maria Inês Gândara Graciano \\ Dissertação apresentada ao Hospital de \\ Reabilitação de Anomalias Craniofaciais, da \\ Universidade de São Paulo, para a obtenção do \\ título de MESTRE em Ciências da Reabilitação. \\ Área de Concentração: Distúrbios da \\ Comunicação Humana
}

Bauru

2006 


\section{UNIVERSIDADE DE SÃO PAULO \\ HOSPITAL DE REABILITAÇÃO DE ANOMALIAS CRANIOFACIAIS}

R. Silvio Marchione, 3-20

Caixa Postal: 620

17012-900 - Bauru - SP - Brasil

Telefone: (0xx14) 3235-8000

Profa. Dra. Suely Vilela - Reitora da USP

Prof. Dr. José Alberto de Souza Freitas - Superintendente do HRAC-USP

Autorizo, exclusivamente para fins acadêmicos e científicos, a reprodução total ou parcial desta dissertação.

Regina Célia Meira Garcia

Bauru, __ de Fevereiro de 2006.

\section{Garcia, Regina Célia Meira}

G165a Aspectos psicossociais e familiares de indivíduos com e sem distúrbios da comunicação decorrentes da fissura labiopalatina. Regina Célia Meira Garcia. Bauru, 2006. 101f.: il.; $30 \mathrm{~cm}$.

Dissertação (Mestrado em Ciências da Reabilitação - Área de Concentração: Distúrbios da Comunicação Humana) - HRAC-USP

Orientador: Maria Inês Gândara Graciano

Descritores: 1. Aspectos psicossociais, 2. Fissuras labiopalatinas.

3. Distúrbios da comunicação. 4. Família. 


\section{FOLHA DE APROVAÇÃO}

\section{Dissertação apresentada e defendida por}

\section{REGINA CÉLIA MEIRA GARCIA}

e aprovada pela Comissão Julgadora em I

Prof.(a) Dr.(a):

Instituição:

Prof.(a) Dr.(a):

Instituição:

Prof.(a) Dr.(a):

Instituição:

Prof.(a) Dr.(a):

Instituição:

Prof.(a) Dr.(a):

Instituição:

Profa. Dra. Inge Elly Kiemle Trindade

Presidente da Comissão de Pós-Graduação do HRAC-USP

Data de depósito da dissertação junto à SPG: 


\section{REGINA CÉLIA MEIRA GARCIA}

24 de Julho de 1956 Nascimento.

Marília - SP

\section{FORMAÇÃO ACADÊMICA}

$1974-1977$

$1981-1982$

Curso de Graduação em Serviço Social, Faculdade de Serviço Social de Lins. Lins/SP.

Curso de Especialização em Administração Hospitalar, União Social Camiliana. Bauru/SP.

$2000-2001$

Curso de Especialização em Serviço Social na Área da Saúde e Reabilitação, no Hospital de Reabilitação de Anomalias Craniofaciais da Universidade de São Paulo, Bauru/SP.

$2003-2006$

Curso de Pós-Graduação em Distúrbios da Comunicação Humana, em nível de Mestrado, no Hospital de Reabilitação de Anomalias Craniofaciais da Universidade de São Paulo, Bauru/SP.

\section{ATIVIDADES PROFISSIONAIS}

1981 - até a presente - Assistente Social do Hospital de Reabilitações de data Anomalias Craniofaciais da Universidade de São Paulo (HRAC/USP) 
Ao meu esposo César e aos meus queridos filhos Laura e Adriano, pelo amor, carinho $e$ compreensão pelas minhas ausências...

Meu eterno amor e gratidão por vocês existirem em minha vida... 
Aे minha querida irmã Carmen sempre presente, compartilhando comigo, tanto os momentos felizes, como os mais dificeis. 
Ao Hospital de Reabilitação de Anomalias CraniofaciaisUSP-Bauru, pela oportunidade e incentivo à produção de conhecimentos.

Ao Prof. Dr. José Al6erto de Souza Freitas, Dr. Gastão, pela competência, apoio e exemplo de solidariedade.

À Maria Inês Gândara Graciano, minha orientadora, pela competência, incentivo, apoio e valiosos ensinamentos ao meu aperfeiçoamento profissional.

À Jennifer, pela confiança em mim depositada, empenho, profissionalismo, presteza e preciosas contribuições para a realização deste trabalho.

Aे Sonia Tebet Mesquita, pela sabedoria, criatividade, valiosas sugestões e principalmente pela amizade sincera $e$ amor. 
Ao Prof. Dr. José Roberto Pereira Lauris, pelas orientações e trato estatístico na pesquisa.

À Unidade de Ensino e Pesquisa, através das bibliotecárias e funcionários, pelo profissionalismo, competência, presteza no levantamento bibliográfico e normatização deste trabalho.

Às Assistentes Sociais Sorma Sueli Formenti e Raquel Bastazini de Camargo, pela amizade, solidariedade, companheirismo, incentivo e apoio.

Às Secretárias do Serviço Social e do Projeto Flórida pela disponibilidade, solicitude e presteza.

Aos pacientes deste estudo, obrigada pela confiança!

A todos que participaram direta ou indiretamente neste estudo, meus sinceros agradecimentos. 


\section{SUMÁRIO}

LISTA DE ABREVIATURAS ............................................... viii

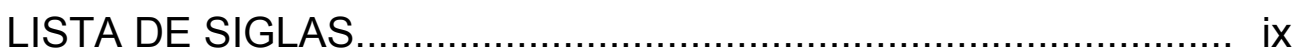

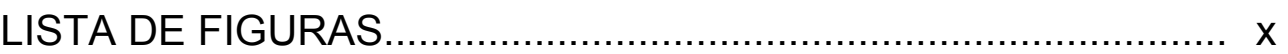

LISTA DE TABELAS ..............................................................

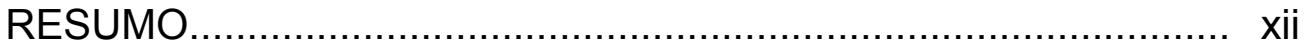

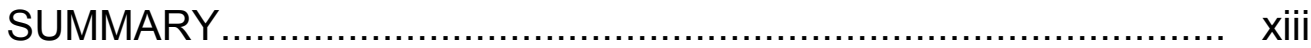

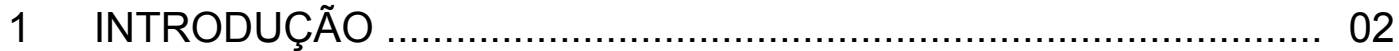

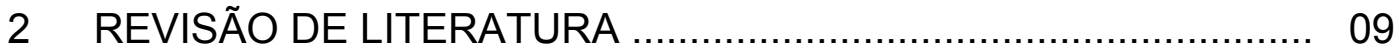

2.1 As malformações labiopalatinas e o processo de reabilitação:

a ação do Serviço Social na equipe.

2.1.1 Os distúrbios da comunicação decorrentes da fissura labiopalatina.................................................... 17

2.2 A família como base no processo de formação e reabilitação... 19

2.2.1 Aspectos psicossociais e os distúrbios da comunicação em indivíduos com fissura labiopalatina: a questão familiar

2.2.2 O estudo social como instrumento estratégico de conhecimento da realidade social: aspectos sociais, econômicos, culturais e familiares.

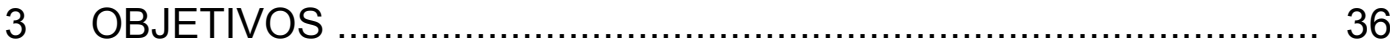

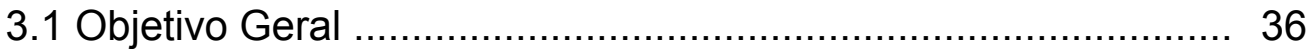

3.2 Objetivos Específicos ...................................................... 36

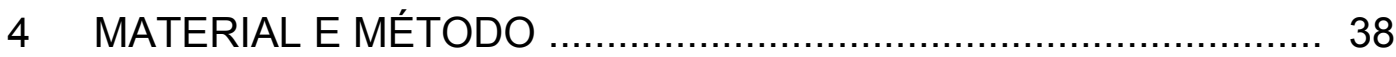

5 RESULTADOS E DISCUSSÃO.................................................. 43

5.1 Estratificação social - Eixo 1.................................................. 45

5.2 Histórico e dinâmica familiar - Eixo 2 ……………............... 50

5.3 Relações sociais do indivíduo e família - Eixo 3...................... 61

5.4 Tratamento reabilitação, recursos organizacionais e comunitários - Eixo 4......................................................... 71

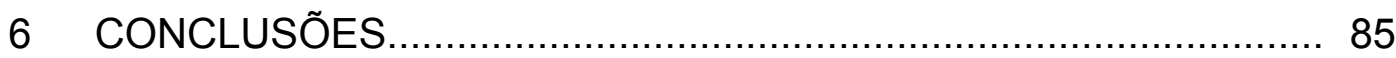

7 REFERÊNCIAS BIBLIOGRÁFICAS ........................................... 91

ANEXOS 


\section{LISTA DE ABREVIATURAS}

A

Art.

$\mathrm{BI}$

BS

Col. Comp.

DAC

DVF

Gin. Comp.

Gin. Inc.

GI

GII

KM

LLP

$\mathrm{M}$

$\mathrm{MI}$

MS

$\mathrm{N}^{\circ}$

OFA

Prec./Insat.

Prim. Comp.

Prim. Inc.

SM
Alta

Artigo

Baixa Inferior

Baixa Superior

Colegial Completo

Distúrbio Articulatório Compensatório

Disfunção Velofaríngea

Ginasial Completo

Ginasial Incompleto

Grupo I

Grupo II

Kilometro

Lesão Lábio Palatal

Média

Média Inferior

Média Superior

Número

Órgãos Fonoarticulatórios

Precária/Insatisfatória

Primário Completo

Primário Incompleto

Salário Mínimo

Trab. Assal./Prod. Trabalhador Assalariado/Produção de bens e serviços

Trab. Assal. Adm. Trabalhador Assalariado Administrativo Técnico-Científico Téc. Cien.

Trab Aut. Trabalhador Autônomo

Trab. Rur. Assal. Trabalhador Rural Assalariado 


\section{LISTA DE SIGLAS}

CPD - Centro de Processamento de Dados

ECA - Estatuto da Criança e do Adolescente

FOB - Faculdade de Odontologia de Bauru

FUNCRAF - Fundação para o Estudo e Tratamento das Deformidades

Crânio-Faciais

HPRLLP - Hospital de Pesquisa e Reabilitação de Lesões Lábio Palatais

HRAC - Hospital de Reabilitação de Anomalias Craniofaciais

IBGE - Instituto Brasileiro de Geografia e Estatística

LOAS - Lei Orgânica da Saúde

PROFIS - Sociedade de Promoção Social do Fissurado Lábio Palatal

REDE PROFIS - Rede Nacional de Associações de Pais e Portadores de

Fissuras Lábio Palatais

SCFBES - Secretaria da Criança, Família e Bem Estar Social do Estado de São Paulo

SUS - Sistema Único de Saúde

TFD - Tratamento Fora do Domicílio

UCE - Unidade de Cuidados Especiais

UF - University of Flórida

USP - Universidade de São Paulo

UTI - Unidade de Terapia Intensiva 


\section{LISTA DE FIGURAS}

Figura 1 - Programas de prestação de serviços - serviço social ambulatorial.

Figura 2 - Programas de prestação de serviços - serviço social de internação.

Figura 3 - Programas de prestação de serviços - serviço social de projetos comunitários.

Figura 4 - Programas de parcerias com recursos governamentais, institucionais e municipais 15

Figura 5 - Programas de ensino e pesquisa do serviço social 15

Figura 6 - Características da estratificação social - GI 46

Figura 7 - Características da estratificação social - GII. 47

Figura 8 - Características da estratificação social - GI + GII 48 


\section{LISTA DE TABELAS}

Tabela 1 - Perfil dos indivíduos segundo informante, gênero, faixa etária e procedência 43

Tabela 2 - Estratificação social ........................................................ 45

Tabela 3 - Situação conjugal e religiosa da família................................. 51

Tabela 4 - Planejamento familiar....................................................... 52

Tabela 5 - Gestação e nascimento....................................................... 55

Tabela 6 - Repercussões do nascimento na família: relacionamento e

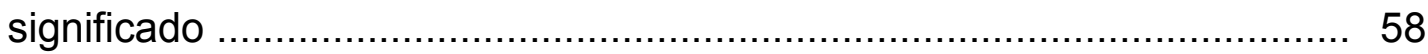

Tabela 7 - Relações sociais da família .............................................. 61

Tabela 8 - Relações sociais do paciente na família.................................... 64

Tabela 9 - Relações sociais do paciente na escola.................................. 66

Tabela 10 - Relações sociais do paciente ............................................. 68

Tabela 11 - Tratamento reabilitador...................................................... 71

Tabela 12 - Tratamento fonoaudiológico .............................................. 75

Tabela 13 - Recursos comunitários para tratamento ............................... 79

Tabela 14 - Satisfação quanto ao tratamento realizado .......................... 82 


\section{RESUMO}

Garcia RCM. Aspectos psicossociais e familiares de indivíduos com e sem distúrbios da comunicação decorrentes da fissura labiopalatina [dissertação]. Bauru: Hospital de Reabilitação de Anomalias Craniofaciais, Universidade de São Paulo; 2006.

Objetivo: Caracterizar e analisar os aspectos psicossociais e familiares de indivíduos com e sem distúrbios da comunicação decorrentes da fissura labiopalatina.

Modelo: Estudo descritivo e comparativo de dois grupos: GI - com distúrbios da comunicação decorrentes da disfunção velofaríngea, alterações dentooclusais e/ou atrasos no desenvolvimento da fala e Gll - indivíduos sem distúrbios da comunicação.

Local: Hospital de Reabilitação de Anomalias Craniofaciais - Universidade de São Paulo, Bauru.

Participantes: 38 indivíduos distribuídos: GI - 20 e GII - 18; acima de 4 anos participantes do "Projeto Flórida", com fissura transforame unilateral, sem outras deficiências e/ou anomalias associadas.

Intervenções: Análise documental e entrevista abordando questões sobre estratificação social, histórico e dinâmica familiar, relações sociais de indivíduos e família, tratamento reabilitador e recursos organizacionais e comunitários.

Resultados/Conclusão: Não foram constatadas relações significativas entre os resultados pós tratamento no que se refere a fala e a condição socioeconômica dos pacientes. Não foram detectadas diferenças significativas entre os aspectos psicossociais e familiares entre os grupos com e sem distúrbios exceto no cotidiano escolar de uma minoria de pacientes (com distúrbios). Embora algumas categorias não apresentaram significância estatística, todas se configuraram como expressivas, e determinantes para 0 conhecimento qualitativo dos aspectos psicossociais e familiares e para a atuação da equipe de reabilitação que, com sua visão de totalidade, busca com os pais e a sociedade, a inclusão social do paciente.

DESCRITORES: aspectos psicossociais, fissuras labiopalatinas, distúrbios da comunicação, família. 


\section{SUMMARY}

Garcia RCM. Psychosocial and familiar aspects of individuals with and without communication disorders related to cleft lip and palate. [Master Thesis]. Bauru: Hospital for Rehabilitation of Craniofacial Anomalies, University of São Paulo; 2006.

Objetive: To characterize and analyze the psychosocial and familiar aspects of individuals with and without communication disorders related to cleft lip and palate.

Design: Descriptive and comparative study of two groups: GI - group of individuals with communication disorders related to velopharyngeal dysfunction, dento-occlusal alterations and/or delays in speech development, and GII group of individuals without communication disorders.

Research Site: Hospital for Rehabilitation of Craniofacial Anomalies, University of São Paulo, Bauru, Brazil.

Participants: 38 individuals distributed into two groups ( $\mathrm{Gl}: \mathrm{N}=20$ and GII: $\mathrm{N}=18$ ); all participants were at least four years of age and were enrolled in the "Florida Project", presenting with unilateral transforame cleft not associated to other malformations or anomalies.

Methods: Interview and data analysis focusing on socioeconomic status, family dynamics and history, individuals and family social relationship, care and management of anomaly and support community resources.

Results/Conclusion: There were no significant differences in the socioeconomic status between children with and without communication disorders. There were no significant differences in the psychosocial and familiar aspects between children with and without communication disorders except regarding school routine which was distinct for a minority in the group with communication disorders. Even though some of the aspects studied did not show significant, the findings provided qualitative information regarding the psychosocial and familiar aspects supporting team management in a search for patient's inclusion in a partnership with the parents and the community.

Key Terms: Psychosocial and familiar aspects, cleft lip and/or palate, communication disorders 


\section{INTRODUÇÃO.}

Caracterizar e analisar os aspectos psicossociais e familiares de indivíduos com e sem distúrbios da comunicação decorrentes da fissura labiopalatina exige de nós inicialmente, a conceituação da saúde a partir da Constituição Federal de 1988 (Brasil 1988), destacando regulamentações importantes no âmbito da Política de Saúde no Brasil, bem como a contextualização do Hospital de Reabilitação de Anomalias Craniofaciais da Universidade de São Paulo - HRAC/USP, local de nossa prática profissional e pesquisadora.

Na Constituição Federal (Brasil 1988), a saúde passa a ser entendida numa perspectiva de articulação de políticas sociais e econômicas e também como direito social universal; os serviços de saúde são caracterizados como de relevância pública; há a criação de um Sistema Único de Saúde (SUS), e a saúde é integrada no espaço mais amplo da seguridade social. Assim sendo, a Constituição Federal de 1988 (Brasil 1988), ao adotar o modelo da seguridade social para assegurar os direitos relativos à previdência, saúde e assistência social, determina que a saúde é direito de todos e dever do Estado.

Como instrumento de regulamentação das ações de saúde no Brasil, foi promulgada a Lei $n^{\circ}$ 8080, de 19 de setembro de 1990 (Lei Orgânica da Saúde - LOAS) (Brasil 2004b), e a Lei no 8142, de 28 de dezembro de 1990 (Sistema Único de Saúde - SUS) (Brasil 2004b), e várias portarias emitidas pelo Ministério da Saúde (Noronha et al 2004).

A Lei $n^{\circ} 8080$, que dispõe sobre as condições para a promoção, proteção e recuperação da saúde, a organização e funcionamento dos serviços correspondentes e dá outras providências, refere em seu Artigo $2^{\circ}$ - "A saúde é um direito fundamental do ser humano, devendo o Estado prover as condições indispensáveis ao seu pleno exercício", e, em seu Artigo $3^{\circ}$ - "A saúde tem como determinantes e condicionantes, entre outros, a alimentação, a moradia, o saneamento básico, o meio ambiente, o trabalho, a renda, a educação, o transporte, o lazer e o acesso aos bens e serviços essenciais; os níveis de saúde da população expressam a organização social e econômica do País"(Brasil 2004a). A Lei n 8142, dispõe sobre a participação da comunidade 
na gestão do Sistema Único de Saúde (SUS) e sobre as transferências intergovernamentais de recursos financeiros na área da saúde e dá outras providências (Brasil 2004b).

Estas leis regulamentam os princípios do SUS, dentre os quais destacamos:

- a universalidade de acesso aos serviços de saúde em todos os níveis de assistência;

- a integralidade de assistência, entendida como um conjunto articulado e contínuo das ações e serviços preventivos e curativos, individuais e coletivos, exigidos para cada caso em todos os níveis de complexidade do sistema;

- a igualdade da assistência à saúde, sem preconceitos ou privilégios de qualquer espécie;

- o direito à informação, às pessoas assistidas sobre sua saúde;

- a participação da comunidade;

- a descentralização político-administrativa, com direção única em cada esfera do governo, dando ênfase para a descentralização dos serviços para os municípios e regionalização e hierarquização da rede de serviços de saúde (Brasil 2004a).

Mesquita (2005) refere que essa nova concepção do sistema de saúde, descentralizado e administrado democraticamente, com a participação da sociedade organizada, afetou as relações de poder político e a distribuição de responsabilidades entre Estado, sociedade e distintos níveis de governo nacional, estadual e municipal - em que os gestores da saúde assumem papel fundamental para concretizar os princípios e diretrizes da reforma sanitária brasileira.

Mantido especialmente com recursos do SUS, o Hospital de Reabilitação de Anomalias Craniofaciais da Universidade de São Paulo (HRAC/USP), é um recurso público de alta tecnologia no atendimento de pessoas com fissuras labiopalatinas, dentre outras anomalias, e de acordo com a portaria 126, de 17 de setembro de 1993, foi cadastrado pelo Ministério da Saúde, no Sistema Integrado de Procedimentos de Alta Complexidade (Brasil 1993b). 
Localizado na cidade de Bauru - Estado de São Paulo, o HRAC tem como finalidade "o ensino, a pesquisa e a extensão de serviços à população portadora de anomalias craniofaciais, distúrbios correlacionados à audição, linguagem e visão" (Brasil 1988 p. 21). É considerado por profissionais nacionais e estrangeiros um dos mais completos centros especializados de reabilitação.

O processo de reabilitação é realizado por uma equipe interdisciplinar constituída por profissionais das áreas de medicina, odontologia, fonoaudiologia, psicologia, serviço social, enfermagem, nutrição, fisioterapia e pedagogia que unem esforços numa filosofia de tratamento global visando a reabilitação morfológica, funcional e psicossocial do paciente (Capelozza Filho e Silva 1992).

Por equipe interdisciplinar, entendemos, com base em Sampaio et al (1989), como a interação de várias disciplinas, numa relação de reciprocidade, de mutualidade e diálogo. Nesta relação, a colaboração entre as diversas áreas é fundamental, não devendo haver supremacia de certa ciência em detrimento de outra. Cabe, portanto, a cada um, reconhecer os limites de seu saber e receber contribuições de outras disciplinas, pois o fundamento da interdisciplinaridade revela que nenhuma ciência esgota o conhecimento. Supõe reciprocidade e interação de conhecimentos, respeitando-se a postura ideológica pessoal e profissional de cada elemento da equipe.

Mesquita (2005) refere que as fissuras labiopalatinas apresentam alterações em nível estético, funcional e psicossocial, e as dificuldades passam a fazer parte do cotidiano das pessoas.

Dentre as alterações funcionais, na área de fonoaudiologia, segundo Altmann et al (1997), os indivíduos com fissuras labiopalatinas podem apresentar comprometimentos nas seguintes áreas: audição, linguagem, fala, voz, órgãos fonoarticulatórios (OFA) e de leitura e escrita, podendo a reabilitação fonoaudiológica ser direcionada para todos estes fatores concomitantemente. A fala é um importante meio de comunicação humana e é por meio dela que o indivíduo estabelece as relações interpessoais e interage com o meio (Suguimoto 2002). 
As alterações relacionadas aos fatores psicossociais ocorrem, portanto, como conseqüência da dificuldade de comunicação e da aparência física comprometida, pois nos dias de hoje, neste mundo capitalista, a estética e a comunicação são atributos exigidos para a pessoa ser reconhecida e valorizada na sociedade.

Preocupados com esta temática - distúrbios da comunicação em fissuras labiopalatinas - em 1991, foi estabelecido um convênio internacional de ensino e pesquisa entre a Universidade de São Paulo (USP), por intermédio do HRAC, com a University of Flórida (UF)/Craniofacial Center.

A partir deste convênio, em 1995 deu-se início ao Projeto de Pesquisa "Função Velofaríngea para a Fala após a Palatoplastia" (Pegoraro-Krook e Williams 1995), conhecido como "Projeto Flórida", visando realizar um estudo prospectivo, controlado e aleatório, para investigar e comparar os resultados de fala e da função velofaríngea para a fala após a palatoplastia pelas técnicas cirúrgicas de Von Langenback e Furlow. Os critérios clínicos de inclusão no Projeto Flórida foram: período de seleção entre 03 de janeiro de 1996 a 21 de dezembro de 2001, com idade até 6 meses, fissura transforame unilateral não operada e sem outras deficiências e/ou anomalias associadas (retardo mental, deficiência auditiva, outras malformações craniofaciais, alto risco, Bandeleta de Simonart e outras malformações), tendo sido selecionados 475 pacientes do HRAC.

O Serviço Social integrou-se à equipe deste projeto, realizando estudo socioeconômico das famílias para conhecimento aproximativo da realidade social dos usuários, colaborando na análise da interrelação de fatores sociais no processo de reabilitação.

No "Projeto Flórida", a cirurgia do lábio (queiloplastia) foi realizada entre as idades de 3 e 6 meses pela técnica cirúrgica de Spina ou de Millard, a do palato (palatoplastia) entre 9 e 12 meses ou entre 15 e 18 meses pela técnica de Von Langenback ou de Furlow; sendo a seleção das técnicas feita aleatoriamente.

A palatoplastia primária tem por objetivo propiciar às estruturas do palato, uma condição anatômica que favoreça a função velofaríngea, a alimentação, a audição e a fala, bem como o desenvolvimento psicossocial 
(Capelozza Filho e Silva 1992). O fracasso em estabelecer uma competência velofaríngea resulta na fala caracterizada pela hipernasalidade e em distúrbios da articulação. Para amenizar os estigmas físicos e funcionais, é necessário que a reparação cirúrgica ocorra o mais precocemente possível, porém, sem comprometer o crescimento facial (Altmann et al 1997), conduta esta defendida pelo "Projeto Flórida".

Segundo pesquisadores do Projeto Flórida, a técnica de Furlow apresentou melhor resultado para fala em crianças com fissuras labiopalatina do que a técnica de Von Langenbeck. A partir deste resultado, anunciado em 20/09/05, destacou-se o mérito da pesquisa por conta de todas as variáveis que puderam ser controladas e por trazer importantes informações para os distúrbios da fala, linguagem e deglutição. Portanto, a resposta à pergunta "Qual entre as duas técnicas cirúrgicas mais difundidas no mundo é a mais adequada para a reabilitação da fala de pessoas com fissura labiopalatina", foi dada e poderá mudar protocolos de atendimento nessa especialidade, não só no Brasil, mas no mundo (Em Foco 2005).

Considerando o índice de pacientes participantes do Projeto "Função Velofaríngea para a Fala após a Palatoplastia" (Projeto Flórida), que mesmo submetidos às cirurgias e acompanhados adequadamente de acordo com o protocolo da pesquisa, apresentavam distúrbios da comunicação ${ }^{1}$ e que, o desenvolvimento da fala da criança pode estar associado à condição socioeconômica, devido a provável influência do ambiente no qual vivem, surgiram os seguintes questionamentos:

1. existem relações significantes entre os resultados pós tratamento com relação à fala e a condição socioeconômica dos pacientes ?

2. existem diferenças significativas entre os aspectos psicossociais e familiares de indivíduos com e sem distúrbios da comunicação?

A partir destes questionamentos - e de nossa participação no Projeto Flórida, como colaboradora da equipe de Serviço Social do HRAC/USP desenvolvemos este projeto: "Aspectos psicossociais e familiares de indivíduos com e sem distúrbios da comunicação decorrentes da fissura labiopalatina".

1 Dados fornecidos pela Coordenadoria do Projeto Flórida do HRAC/USP. 
O segundo capítulo refere-se à Revisão de Literatura, que aborda as malformações, distúrbios da comunicação e processo de reabilitação das fissuras labiopalatinas numa perspectiva interdisciplinar; a família e seus aspectos psicossociais, bem como o estudo social como instrumento estratégico de conhecimento da realidade.

No terceiro capítulo, definimos os objetivos de caracterizar e analisar os aspectos psicossociais e familiares de indivíduos com fissura labiopalatina, estudar a interrelação entre os diferentes estratos sociais e fala, dentre outros.

O quarto capítulo, refere-se ao Material e Método utilizados na pesquisa, com uma amostra de 38 indivíduos, mediante abordagem quanti-qualitativa.

No quinto capítulo, apresentamos e discutimos os resultados, correlacionando-os à revisão de literatura, a partir de 4 eixos de análise: estratificação social; histórico e dinâmica familiar; relações sociais do indivíduo e família; tratamento reabilitador, recursos organizacionais e comunitários.

A importância desta pesquisa revela-se pela possibilidade de responder aos questionamentos sobre a correlação (ou não) entre os aspectos psicossociais e distúrbios da comunicação, mediante o aprofundamento do estudo social das famílias, visando tanto ao conhecimento da realidade como à intervenção nas questões sociais.

Revela-se ainda, pela possibilidade de colaborar com a construção de conhecimentos sobre os aspectos psicossociais e familiares de indivíduos com fissuras labiopalatinas. 


\section{REVISÃO DE LITERATURA.}

Pretendemos com este capítulo uma sustentação teórica para as questões envolvidas em nosso estudo, contextualizando literaturas de apoio para melhor análise e compreensão dos resultados.

Abordamos inicialmente uma revisão literária sobre as malformações labiopalatinas, o processo de reabilitação e os distúrbios da comunicação, e num segundo momento, sobre a família como base no processo de formação e reabilitação, os aspectos psicossociais e o estudo social como instrumento estratégico de conhecimento da realidade social.

\section{1 - As malformações labiopalatinas e o processo de reabilitação: a ação do Serviço Social na equipe.}

Com base em conceitos vigentes na etiologia das fissuras labiopalatinas, Capelozza Filho et al (1988), afirmam que os defeitos congênitos estruturais que afetam a face humana manifestam-se em diferentes formas clínicas, variando desde as fissuras labiopalatinas mais comuns ou raras, até as mais complexas malformações craniofaciais, também denominadas de fissuras ou lesões. Estas malformações são resultantes da falta de coalescência dos processos maxilar, mandibular e frontonasal, pois o desenvolvimento insuficiente de um ou mais desses processos, ou a ocorrência de falhas na desintegração da superfície epitelial nas regiões de contato entre os processos, resultarão na ocorrência das mais variadas fissuras.

Bzoch (2004) relata que essas falhas ou quebras da estrutura óssea tecidual nas junções durante o desenvolvimento embriológico podem ocorrer no final da quinta semana, originando a fenda no lábio, na ponte alveolar ou no seguimento intermaxilar. Com relação ao palato, que deverá estar completo na décima segunda semana, a ocorrência de falhas no seu processo de desenvolvimento ocorrerá por volta da sétima ou oitava semana de vida gestacional. 
O HRAC utiliza-se da classificação das fissuras labiopalatinas de Spina, com uma modificação proposta por Silva Filho et al (1992), que inclui as fissuras medianas no grupo II, ou seja:

$>$ Grupo I-Fissuras pré-forame incisivo

a) Unilateral - direita ou esquerda $\rightarrow$ completa / incompleta

b) Bilateral $\rightarrow$ completa / incompleta

c) Mediana $\rightarrow$ completa / incompleta

$>$ Grupo II - Fissuras transforame incisivo

a) Unilateral $\rightarrow$ direita / esquerda

b) Bilateral

c) Mediana

$>$ Grupo III - Fissuras pós-forame incisivo

Completa / Incompleta

$>$ Grupo IV - Fissuras raras da face

Esta classificação, simples e objetiva, fundamenta-se na teoria embriológica que reconhece os mecanismos independentes de formação das estruturas anteriores (palato primário) e posteriores (palato secundário) ao forame incisivo, ponto de referência anatômico escolhido para essa classificação.

As fendas pré-forames são as de lábio, as pós-forames são as do palato (céu da boca) e as transforames são as que envolvem lábio, alvéolo (gengiva) e palato, e são popularmente conhecidas como lábio-leporino (fissuras labiais) e/ou goela de lobo (fissuras palatinas).

Há uma controvérsia muito grande na literatura e muito pouco se conhece sobre a etiologia das fissuras labiopalatinas. Para tentar explicá-las, dois fatores são imputados: os fatores genéticos e os ambientais que podem atuar a sós ou em associação. Contudo, a determinação dos fatores hereditários e sua comprovação são difíceis na espécie humana.

Assim, a maior parte das fissuras é causada pela interação de muitos fatores genéticos e ambientais, individualmente indistinguíveis, que consiste em causas multifatoriais. Esta teoria, por permitir avaliar o risco de recorrência é a mais aceita na literatura (Capelozza Filho et al 1988). 
Segundo Nagem Filho et al (1968), as malformações labiopalatinas situam-se entre o terceiro e o quarto defeito congênito mais freqüente, sendo a prevalência de um para cada 650 nascimentos. Com base nesta prevalência e na população brasileira apontada no Censo de 2000, do Instituto Brasileiro de Geografia e Estatística (2005), num total de 169.799.170 habitantes, estima-se que existam no Brasil 261 mil portadores de fissuras labiopalatinas.

Segundo a Política Nacional para a Integração da Pessoa Portadora de Deficiência (Brasil 2006a p.6), "reabilitação é o processo de duração limitada e com objetivo definido, destinado a permitir que a pessoa com deficiência alcance o nível físico, mental ou social funcional ótimo, proporcionando-lhe os meios de modificar sua própria vida, podendo compreender medidas visando a compensar a perda de uma função ou uma limitação funcional e facilitar ajustes ou reajustes sociais".

A reabilitação, enquanto serviço, é um conjunto de ações de atenção à saúde e, portanto, um componente imprescindível de promoção, prevenção e assistência às pessoas, na manifestação de sua saúde e bem estar, bem como à sua família e comunidade (Brasil 1993a).

A reabilitação, enquanto processo individual, diz respeito ao desenvolvimento de capacidades adaptativas do indivíduo, nas diferentes fases de sua vida, e confunde-se com o processo de desenvolvimento ótimo da pessoa com deficiência, nos aspectos funcionais, físicos, psíquicos, educacionais, sociais, profissionais e ocupacionais (Brasil 1993a).

De acordo com Ferrari e Damasceno (2005), a reabilitação é hoje entendida como um processo que ultrapassa a recuperação de funções perdidas e/ou alteradas. Volta-se à construção e/ou recuperação de uma vida digna e plena, entendida como vida com qualidade.

Para Graciano (1988), a reabilitação do indivíduo com fissura labiopalatina depende de fatores como: a extensão da lesão, a idade em que iniciou o tratamento, o seguimento do tratamento e a assistência integrada da equipe interdisciplinar. Aqueles que iniciam o tratamento quando criança e têm possibilidade de seguimento, o prognóstico é melhor. O trabalho em equipe é fundamental e cada área possui o seu campo de atuação, no sentido de prover um tratamento integral aos pacientes atendidos, englobando aspectos 
estéticos, funcionais e psicossociais. É a interação destas áreas que possibilita a compreensão do paciente no seu todo, como ser humano em sua totalidade. A reabilitação pressupõe, assim, a cooperação entre os profissionais e os serviços no desenvolvimento integral da pessoa com deficiência bem como a participação da sociedade e dos próprios reabilitandos.

Amaral (1997) refere também que a reabilitação supõe a união de esforços de uma equipe de profissionais por meio de uma ação interdisciplinar preventiva e curativa junto à pessoa com o defeito facial e seus familiares e comunidade, para minimizar seus problemas e propiciar condições para o pleno desenvolvimento de suas capacidades físicas, psicológicas, afetivas e sociais.

Esta ação, como refere Rodrigues On (1995), requer originalidade e a diversidade do conhecimento por parte de cada profissional permitindo a pluralidade de contribuições para compreender a totalidade do sujeito de nossa ação.

Nesta equipe, cabe ao assistente social assumir desafios, empreendendo uma prática social educativa e política de enfrentamento às questões sociais, tendo como meta contribuir para a inclusão das pessoas com anomalias craniofaciais nas políticas sociais, viabilizando especialmente 0 acesso aos serviços de saúde e reabilitação.

O assistente social, em uma equipe de saúde, é o profissional que identifica as necessidades dos usuários e as condições sociais em que ele está inserido. A partir dessa visão de totalidade, passa a interpretar junto à equipe aspectos relevantes no âmbito social. Dentro desta perspectiva, deverá estar sempre bem informado quanto aos objetivos e normas da instituição, reconhecer as necessidades dos usuários e disponibilizar os recursos existentes, além de identificar falhas e deficiências, a serem corrigidas (Silva e Lessa 1998).

Segundo Frossard e Matos (1998), o assistente social na saúde tem por objetivo identificar os aspectos sociais, econômicos e culturais relacionados ao processo saúde-doença buscando formas de enfrentamento individual e coletiva para estas questões. Para este trabalho são mobilizados os recursos institucionais e comunitários no campo da assistência e desenvolvimento 
social, tendo-se como perspectiva a avaliação/construção das políticas públicas que efetivem os direitos básicos de cidadania.

Dentre suas principais competências, em consonância com a Lei 8662/93 (Brasil 2004d), que regulamenta a profissão do Assistente Social, destacamos: coordenar, executar e avaliar planos, programas e projetos no âmbito de atuação do Serviço Social, com participação da sociedade civil; encaminhar providências e prestar orientação social a indivíduos, grupos e a população; orientar indivíduos e grupos de diferentes segmentos sociais no sentido de identificar recursos e de fazer uso dos mesmos no atendimento e na defesa de seus direitos; realizar estudos socioeconômicos com os usuários para fins de benefícios e serviços sociais; planejar, executar e avaliar pesquisas que contribuam para a análise da realidade social e para subsidiar ações profissionais.

No HRAC, o Serviço Social tem como objetivo principal viabilizar o acesso e a continuidade do tratamento de pessoas portadoras de anomalias craniofaciais, visando sua inclusão numa política de saúde em interface com a assistência social (Graciano et al 2003). Tem como eixo fundamental a prevenção e/ou a intervenção nesses casos, por meio de seus diferentes programas sociais de apoio à equipe interdisciplinar no processo de reabilitação.

O Serviço Social constitui-se em uma Diretoria Técnica de Serviço, um serviço de apoio e atendimento ao tratamento da Divisão Hospitalar, compreendendo três seções: Serviço Social Ambulatorial, Serviço Social de Internação e Serviço Social de Projetos Comunitários, desenvolvendo programas de prestação de serviços, ensino e pesquisa (Graciano et al 2003), conforme figuras 1, 2, 3, 4 e 5 a seguir:

\begin{tabular}{|l|l|}
\hline \multicolumn{1}{|c|}{ PROGRAMAS } & \multicolumn{1}{|c|}{ OBJETIVOS } \\
\hline Acolhimento e atendimento de casos novos & $\begin{array}{l}\text { Contribuir no processo de humanização e } \\
\text { acolhimento aos casos novos, preparando-os } \\
\text { para o início e seguimento do tratamento. }\end{array}$ \\
\hline $\begin{array}{l}\text { Atendimento ambulatorial: plantão social "in } \\
\text { loco" e agendamento }\end{array}$ & $\begin{array}{l}\text { Atender as demandas sociais dos usuários } \\
\text { prestando assistência e serviços sociais } \\
\text { enquanto direito de cidadania. }\end{array}$ \\
\hline $\begin{array}{l}\text { Acolhimento e humanização na sala de } \\
\text { espera: "Sinta-se em casa" }\end{array}$ & $\begin{array}{l}\text { Qualificar o tempo na sala de espera por } \\
\text { meio de atividades educativas, culturais e } \\
\text { recreativas. }\end{array}$ \\
\hline
\end{tabular}


Continuação

\begin{tabular}{|l|lr|}
\hline $\begin{array}{l}\text { Atendimento ambulatorial grupal para } \\
\text { informação de recursos sócio-comunitários e } \\
\text { troca de experiências }\end{array}$ & $\begin{array}{l}\text { Viabilizar a garantia de direitos sociais } \\
\text { acionando e criando fluxos e informação e } \\
\text { participação. }\end{array}$ \\
\hline $\begin{array}{l}\text { Atendimento à gestante e familiares com } \\
\text { diagnóstico de bebê portador de anomalia } \\
\text { craniofacial (ultrassonografia) }\end{array}$ & $\begin{array}{l}\text { Prestar apoio psicossocial e orientação à } \\
\text { gestante e/ou família. }\end{array}$ \\
\hline $\begin{array}{l}\text { Atendimento social a casos de Bauru - "Projeto } \\
\text { Bauru" }\end{array}$ & $\begin{array}{l}\text { Prestar acolhimento, atendimento e e } \\
\text { assistência contínua a casos novos e em } \\
\text { seguimento; prevenir e intervir nos casos de } \\
\text { abandono de tratamento e propiciar a adoção } \\
\text { nacional ou internacional nos casos de } \\
\text { abandono familiar. }\end{array}$ \\
\hline
\end{tabular}

Fonte: Plano de ação do serviço social: área de anomalias craniofaciais: 2003-2006, HRAC/USP.

\section{Figura 1 - Programas de prestação de serviços - serviço social ambulatorial}

\begin{tabular}{|c|c|}
\hline PROGRAMAS & OBJETIVOS \\
\hline $\begin{array}{l}\text { Integração e e dinamização } \\
\text { (internação, acompanhamento, alta e óbito) }\end{array}$ & $\begin{array}{l}\text { Prestar apoio psicossocial e contribuir no } \\
\text { processo de integração e humanização } \\
\text { durante o período de internação. }\end{array}$ \\
\hline $\begin{array}{l}\text { Assistência hospitalar aos usuários: plantão } \\
\text { social "in loco" e emergencial }\end{array}$ & $\begin{array}{l}\text { Atender às demandas sociais dos usuários } \\
\text { no período de hospitalização prestando } \\
\text { assistência e serviços sociais. }\end{array}$ \\
\hline $\begin{array}{l}\text { Acolhimento e humanização de } \\
\text { acompanhantes da Unidade de Cuidados } \\
\text { Especiais (U.C.E.) e da Unidade de Terapia } \\
\text { Intensiva (UTI) - "Bem Estar" }\end{array}$ & $\begin{array}{l}\text { Favorecer a convivência social grupal, } \\
\text { proporcionando acolhimento, integração e } \\
\text { humanização durante o período de } \\
\text { internação. }\end{array}$ \\
\hline
\end{tabular}

Fonte: Plano de ação do serviço social: área de anomalias craniofaciais: 2003-2006, HRAC/USP.

Figura 2 - Programas de prestação de serviços - serviço social de internação

\begin{tabular}{|l|l|}
\hline \multicolumn{1}{|c|}{ PROGRAMAS } & \multicolumn{1}{|c|}{ OBJETIVOS } \\
\hline Agentes multiplicadores: pais coordenadores & $\begin{array}{l}\text { Capacitar pais elou pacientes adultos para } \\
\text { atuarem no país como agentes } \\
\text { multiplicadores do HRAC. }\end{array}$ \\
\hline Parceria com Prefeituras Municipais & $\begin{array}{l}\text { Manter intercâmbio com as prefeituras } \\
\text { municipais viabilizando o encaminhamento } \\
\text { de casos, bem como apoio à locomoção e } \\
\text { designação de representantes do Serviço } \\
\text { Social para parceria. }\end{array}$ \\
\hline Carona Amiga & $\begin{array}{l}\text { Propiciar a união das pessoas e } \\
\text { racionalização de uso de transporte, } \\
\text { agrupando os pacientes por município, de } \\
\text { forma a facilitar o processo de reabilitação } \\
\text { e organização popular. }\end{array}$ \\
\hline Capacitação de representantes comunitários & $\begin{array}{l}\text { Capacitar profissionais dos diversos } \\
\text { municípios para atuarem como } \\
\text { representantes comunitários, visando apoio } \\
\text { ao processo de reabilitação. }\end{array}$ \\
\hline Parceria com Promotorias Públicas & $\begin{array}{l}\text { Prevenir elou intervir nos casos de } \\
\text { abandono de tratamento, assegurando-lhes } \\
\text { direitos de cidadania. }\end{array}$ \\
\hline $\begin{array}{l}\text { Prevenção e intervenção a casos de abandono } \\
\text { de tratamento }\end{array}$ & $\begin{array}{l}\text { Viabilizar o acesso e seguimento do } \\
\text { tratamento dos usuários do HRAC, visando } \\
\text { sua inclusão. }\end{array}$ \\
\hline
\end{tabular}


Continuação

Assessoria às associações, núcleos e sub-sedes do país

Assessoria à REDE PROFIS (Rede Nacional de Associações de Pais e Portadores de Fissuras Lábio Palatais)

Parceria com o Programa de Descentralização do HRAC/USP

Colaborar no processo de capacitação de recursos humanos com as associações e núcleos.

Participar nas ações de fortalecimento da REDE PROFIS, cujo objetivo é congregar, integrar, representar e defender os interesses institucionais de suas associadas.

Colaborar com a equipe do programa de descentralização dos serviços do HRAC, no estudo e implantação de unidades de atendimento nas regiões/Estados do país.

Fonte: Plano de ação do serviço social: área de anomalias craniofaciais: 2003-2006, HRAC/USP.

Figura 3 - Programas de prestação de serviços - serviço social de projetos comunitários

\begin{tabular}{|l|l|}
\hline \multicolumn{1}{|c|}{ PROGRAMAS } & \multicolumn{1}{|c|}{ OBJETIVOS } \\
\hline $\begin{array}{l}\text { Mobilização do Tratamento Fora do Domicílio } \\
\text { (TFD) do Sistema Único de Saúde (SUS) }\end{array}$ & $\begin{array}{l}\text { Assegurar o benefício - TFD - aos usuários } \\
\text { do SUS, (passagens de ida e volta e ajuda } \\
\text { de custo ao paciente/acompanhante em } \\
\text { tratamento no HRAC). }\end{array}$ \\
\hline Assistência social integrada: HRAC e PROFIS & $\begin{array}{l}\text { Desenvolver programas de assistência } \\
\text { integradas entre o HRAC e PROFIS, } \\
\text { viabilizando o acesso e a continuidade do } \\
\text { tratamento através da mediação do Serviço } \\
\text { Social. }\end{array}$ \\
\hline $\begin{array}{l}\text { Viabilização de transporte aéreo por meio do } \\
\text { "Programa DoAr" (Varig) }\end{array}$ & $\begin{array}{l}\text { Viabilizar o transporte aéreo para } \\
\text { instituições da área da saúde, que assistam } \\
\text { a pacientes carentes, possibilitando o } \\
\text { tratamento e o retorno à cidade de origem. }\end{array}$ \\
\hline
\end{tabular}

Fonte: Plano de ação do serviço social: área de anomalias craniofaciais: 2003-2006, HRAC/USP.

Figura 4 - Programas de parcerias com recursos governamentais, institucionais e municipais

\begin{tabular}{|c|c|}
\hline PROGRAMAS & OBJETIVOS \\
\hline $\begin{array}{l}\text { Formação de recursos humanos em Serviço } \\
\text { Social (supervisão de estagiários, cursos de } \\
\text { malformações, aprimoramento e especialização) }\end{array}$ & $\begin{array}{l}\text { Colaborar com a formação de recursos } \\
\text { humanos do Serviço Social capacitando-os } \\
\text { para atuar no campo da saúde e } \\
\text { reabilitação }\end{array}$ \\
\hline $\begin{array}{lllll}\begin{array}{l}\text { Organização } \\
\text { científicos }\end{array} & \text { e participação em } & \text { eventos } \\
\end{array}$ & $\begin{array}{l}\text { Divulgar trabalhos técnico-científicos do } \\
\text { Serviço Social em diferentes eventos } \\
\text { (nacionais e internacionais), participando do } \\
\text { processo de reciclagem, de formação e } \\
\text { troca de experiências entre profissionais e } \\
\text { pesquisadores. }\end{array}$ \\
\hline Desenvolvimento de pesquisas sociais & $\begin{array}{l}\text { Desenvolver e/ou (co)orientar pesquisas de } \\
\text { Serviço Social, contribuindo para a } \\
\text { construção de conhecimentos na área }\end{array}$ \\
\hline articipação em pesquisas & Colaborar na análise da realidade social \\
\hline
\end{tabular}

Fonte: Plano de ação do serviço social: área de anomalias craniofaciais: 2003-2006, HRAC/USP.

Figura 5 - Programas de ensino e pesquisa do serviço social

Considerando que o tratamento reabilitador é longo e complexo, demandando vários anos e diversas dificuldades enfrentadas pelas famílias 
(financeiras, geográficas e familiares, e outras), o Serviço Social é imprescindível na equipe, cumprindo o seu objetivo principal, pois a maioria dos pacientes se encontra em processo de reabilitação ou reabilitados. Dos 41.905 (100\%) pacientes matriculados ${ }^{2}, 77,6 \%$ estão em situação regular (alta - 9,2\% , em tratamento - 68,4\%), e somente 16,8\% irregulares (ignorados - 2,0\%, interrupção - 14,8\%) além dos 2,7\% óbitos e 2,9\% não caracterizados.

Portanto, o Serviço Social do HRAC, por meio de seus diferentes programas, tem favorecido a emancipação e a inclusão social das pessoas com deficiência na sociedade, viabilizando e efetivando direitos de cidadania no acesso às políticas sociais.

A classificação dos tipos de deficiência em vigor (Brasil 2006a, 2006b) abrange as deficiências: física, visual, mental e múltipla. A deficiência física é definida como alteração completa ou parcial de um ou mais segmentos do corpo humano, acarretando o comprometimento da função física, apresentando-se sob a forma de paraplegia, paraparesia, monoplegia, monoparesia, tetraplegia, tetraparesia, triplegia, triparesia, hemiplegia, hemiparesia, ostomia, amputação ou ausência de membro, paralisia cerebral, nanismo, membros com deformidade congênita ou adquirida, exceto as deformidades estéticas $\mathrm{e}$ as que não produzam dificuldades para o desempenho de funções.

Considerando que a inclusão das malformações e/ou anomalias craniofaciais (dentre elas as fissuras labiopalatinas) não foram explicitadas nos decretos, dependendo portanto da interpretação de diferentes áreas (jurídica, social e outras), o Serviço Social do HRAC e a REDE PROFIS têm se mobilizado nesse sentido junto a Conselhos de Direitos e Conferências sobre assuntos das pessoas portadoras de deficiência, tanto em nível municipal como estadual.

A necessidade de inclusão das fissuras labiopalatinas como deficiência, justifica-se pois dependendo da complexidade da fissura, o grau das alterações tanto estéticas funcionais como psicossociais precisa ser avaliado. Dentre estas alterações, destacamos a gravidade dos distúrbios da comunicação

\footnotetext{
${ }^{2}$ Dados fornecidos pelo Centro de Processamento de Dados do HRAC em dezembro/2004
} 
associado às fissuras, que podem comprometer o acesso a educação e ao trabalho e conseqüentemente o processo de inclusão social.

\subsection{1 - Os distúrbios da comunicação decorrentes da fissura labiopalatina.}

Segundo Suguimoto (2002 p. 2), "a comunicação é o processo pelo qual o indivíduo pode se integrar e interagir com o meio social". Para estabelecer relações interpessoais, utiliza-se de um veículo fundamental que é a fala.

Complementa a autora que os indivíduos com fissuras labiopalatinas podem apresentar distúrbios da comunicação e, dentre estes, as alterações na fala são marcantes. Destas, as mais freqüentemente encontradas são as relacionadas à disfunção velofaríngea, tais como: hipernasalidade, emissão de ar nasal, diminuição de pressão aérea intra-oral, ronco nasal, mímica facial e distúrbio articulatório compensatório. São também encontrados distúrbios de fala relacionados à má-oclusão dentária, como as modificações nos pontos articulatórios, uma vez que alterações dento-oclusais podem estar presentes nestes casos. Também estes indivíduos podem apresentar atrasos no desenvolvimento da fala e/ou da linguagem.

Relata ainda que, um fator que pode influenciar o desenvolvimento da fala desses indivíduos é a gravidade da fissura, isto é, a quantidade de estruturas acometidas, visto que a produção de fala correta depende, também, da integridade anatômica das estruturas da cavidade oral.

"O tratamento cirúrgico, visando o restabelecimento anatômico e funcional do palato, deve ser realizado o mais precocemente possível, a fim de propiciar condições estruturais adequadas da cavidade oral e da função velofaríngea, evitando ou atenuando as alterações da fala, que estigmatizam o indivíduo com fissura, no que se refere aos aspectos social e psicológico" (Suguimoto 2002 p. 2).

Ressalta a autora que, na prática clínica, observa-se que, mesmo após a realização da palatoplastia primária antes dos 24 meses de idade, a disfunção velofaríngea pode persistir, levando a alterações na fala.

A literatura revela que a presença de disfunção velofaríngea e de seus sintomas característicos é menor em indivíduos submetidos precocemente à 
palatoplastia primária e que existe uma relação entre os resultados de fala e as diferentes técnicas cirúrgicas preconizadas (Suguimoto 2002).

Segundo Altmann et al (1997), o desenvolvimento de linguagem nas crianças portadoras de fissuras labiopalatinas é similar ao de crianças normais no que concerne aos mecanismos lingüísticos, sendo que os fatores ambientais, culturais e emocionais podem influir positiva ou negativamente neste desenvolvimento. As hospitalizações freqüentes, a superproteção ou a falta de estimulação por parte dos familiares são fatores que atuam direta ou indiretamente na aquisição da linguagem.

Refere-se que para o desenvolvimento da comunicação e da linguagem, é muito importante a quantidade e qualidade dos padrões lingüísticos recebidos pela criança. As características efetivas das relações entre a criança e o meio são básicas para favorecer o uso da comunicação como meio fundamental do relacionamento interpessoal.

Relata ainda que, para a aquisição da linguagem da criança faz-se necessário a participação dos que a cercam, não apenas falando à sua volta, mas que se fale com ela, que se aprenda a ouvi-la e a considerá-la um verdadeiro interlocutor. $\mathrm{O}$ adulto pode bloquear o caminho pedagógico da criança ao não se interessar pelo que ela diz, ao pedir que se cale, ao corrigi-la sistematicamente, exigindo a forma correta, ou ao apresentar-lhe pergunta e resposta ao mesmo tempo. Desta forma, a qualidade e a dinâmica da comunicação vão determinar o impacto da linguagem do adulto sobre a criança (Altmann et al 1997).

No tratamento da fissura palatina, mesmo quando os melhores esforços são empreendidos e os melhores cuidados são tomados, a revisão de literatura indica que em torno de $10 \%$ à $30 \%$ das cirurgias primárias para o fechamento da fissura palatal são mal sucedidas - (Morris 1973, Riski 1979, Bradley 1997, Suguimoto 2002 e Seagle 2004). Tais resultados são documentados por meio do diagnóstico da disfunção velofaríngea (DVF), primeiro pela identificação da presença da hipernasalidade, de escape de ar nasal e/ou de distúrbio articulatório compensatório (DAC), e depois pela caracterização instrumental da DVF por meio da avaliação nasoendoscópica e/ou videofluoroscópica da 
função velofaríngea, técnicas que permitem a definição de condutas terapêuticas adequadas.

A estatística acima apresentada se repete nos vários centros ao redor do mundo com uma tendência a melhorar com o passar do tempo em virtude dos avanços tecnológicos dos estudos científicos que têm melhor definido as indicações cirúrgicas de acordo com as populações que melhor podem se beneficiar de cada procedimento.

Em particular, no HRAC, Suguimoto (2002) fez revisão dos resultados de fala de 342 casos e encontrou que $31 \%$ apresentaram sinais de DVF após cirurgia primária do palato, tendo, portanto indicação para receber tratamento secundário para correção da DVF. A correção da DVF nos pacientes cuja cirurgia primária foi mal sucedida pode ser feita por meio da cirurgia secundária, da prótese de palato, de implantes na parede posterior da faringe e/ou de combinações destes vários tipos de tratamento com a fonoterapia.

Considerando a complexidade dos distúrbios da comunicação nos indivíduos com fissuras labiopalatinas, a atuação do fonoaudiólogo é fundamental, a quem cabe orientar, diagnosticar e planejar os procedimentos terapêuticos por meio de um programa de atendimento integrado à equipe interdisciplinar.

\section{2 - A família como base no processo de formação e reabilitação.}

Para o desenvolvimento saudável de uma criança e de um adolescente, a família ocupa lugar de destaque, segundo o Estatuto da Criança e do Adolescente (ECA) em seu Capítulo III que trata do Direito à Convivência Familiar e Comunitária (Brasil 2004c).

Não há uma definição única de família, na forma de um modelo de "família ideal". Podemos, entretanto, pensar em algumas condições que podem estar presentes, como assegura o ECA em seu Art. 19 que "toda criança ou adolescente tem direito a ser criado e educado no seio da sua família e, excepcionalmente, em família substituta, assegurada a convivência familiar e comunitária...", e em seu Art. $4^{\circ}$ que "é dever da família, da comunidade, da sociedade em geral e do poder público assegurar, com absoluta prioridade, a 
efetivação dos direitos referentes à vida, à saúde, à alimentação, à educação, ao esporte, ao lazer, à profissionalização, à cultura, à dignidade, ao respeito, à liberdade e à convivência familiar e comunitária" (Brasil 2004c).

Estas condições necessárias para o desenvolvimento como pessoa apontam que é dever da família assegurar a efetivação desses direitos.

"Ao co-responsabilizar a comunidade, sociedade em geral e poder público na efetivação dos direitos citados, fica implícito que, quando a família não estiver cumprindo sua função provedora e formadora, essas outras agências deverão subsidiá-la, informando-a e instrumentando-a, e, excepcionalmente, afastando-a ou substituindo-a em algumas de suas funções" (Szymanski 1992 p.3).

Ferreira (1975 p. 609) define família no sentido etimológico da palavra "pessoas aparentadas que vivem em geral na mesma casa, particularmente o pai, a mãe e os filhos". Numa definição ampla, teríamos uma família "quando pessoas convivem assumindo o compromisso de uma ligação duradoura entre si, incluindo uma relação de cuidado entre os adultos e deles para com as crianças e idosos que aparecem nesse contexto" (Szymanski 1992 p. 35).

José Filho (2002 p. 15) ressalta que "muito além de uma simples definição, a família tem sua importância fundamental não apenas no âmbito da reprodução biológica, mas principalmente, enquanto mediadora de seus membros com a sociedade. Ela proporciona a construção de nossa primeira identidade e nos insere nas relações sociais em nível emocional, cultural e socioeconômico. A 'família' é o primeiro referencial e permeia toda a nossa existência".

Segundo José Filho (2002 p. 58), para efeito de conceituação operacional, segundo o documento "Política Social de Família" da Secretaria da Criança, Família e Bem Estar Social do Estado de São Paulo (SCFBES), "a família tem que ser entendida enquanto uma unidade em movimento, sendo constituída por um grupo de pessoas que, independente de seu tipo de organização e de possuir ou não laços consangüíneos, busca atender:

- às necessidades afetivo-emocionais de seus integrantes, através do estabelecimento de vínculos afetivos, amor, afeto, aceitação, sentimento de pertença, solidariedade, apego e outros; 
- às necessidades de subsistência-alimentação, proteção (habitação, vestuário, segurança, saúde, recreação, apoio econômico);

- às necessidades de participação social, freqüentar centros recreativos, escolas, igrejas, associações, locais de trabalho, movimento, clubes (de mães, de futebol e outros)."

José Filho (2002) salienta que a família, no sentido mais profundo da palavra, tem uma imensa significação na vida humana, pois é dentro dela que o ser humano nasce e morre, e, no entanto, é dentro desse quadro de conflitos e alegrias que o ser humano muitas vezes não percebe a importância de se ter um ambiente familiar que Ihe proporcione uma vida plena e feliz sempre redescobrindo novos caminhos.

O mesmo autor destaca que podemos analisar a família partindo-se das funções que ela desempenha na sociedade, ou seja: funções de ordem biológica e demográfica garantem a reprodução e a sobrevivência do ser humano; função de ordem educadora e socializadora transmite conhecimentos, valores, afetos através de uma comunicação verbal corpórea tão importante nas relações interpessoais; função de ordem econômica (produtoras e consumidoras) que se dá no campo do trabalho; função de seguridade, que cuida da seguridade física, moral, afetiva, criando uma dimensão de tranqüilidade; e função recreativa, que se traduz em atividades diversas que rompem o tédio, as tensões, como as festas em família (aniversário, casamento e outras). Estas funções determinaram em épocas distintas, considerando a cultura dos povos, diferentes modelos e concepções de família.

Segundo Ariés (1978), a família nuclear - quer dizer, pai, mãe e filhos da forma como é definida hoje em dia, não foi sempre assim; foi a conseqüência de mudanças na forma de atuação de outras instituições, como o Estado e a Igreja que, há cerca de três séculos começaram a valorizar o "sentimento de família". Isto significa que os laços familiares começaram a ser reconhecidos socialmente e a educação e criação de crianças nascidas da união de um casal passou a ser cada vez mais da responsabilidade da família.

Destaca Poster (1979) que foi por volta do século XVIII que a família começou a delimitar uma área maior de vida particular, e os costumes contemporâneos foram fortemente influenciados por esse sentimento de família 
que se desenvolveu na Europa a partir do século XVI, especialmente nas classes mais abastadas. Entre esses costumes está o de cada família morar na sua casa e ser responsável pela educação de seus filhos. Além disso, a comunidade tem diminuída a sua interferência em assuntos domésticos.

Mais tarde (século XIX e início do século $X X$ ) as famílias das classes trabalhadoras também acabaram adotando o modelo da família nuclear burguesa, quando foram forçadas a deixar o campo e ingressar no trabalho em indústrias nas cidades.

A família nuclear burguesa, a partir desse modelo, organizou-se em torno da figura do pai, fechada em sua intimidade e com um determinado padrão de educação para seus filhos.

Este modelo foi trazido para o Novo Mundo, cujos habitantes já tinham uma organização social diferente, sendo alguns grupos originários de sociedades com tradição matriarcal; mas foi o modelo europeu dos colonizadores que se impôs como modelo social de família (Szymanski 1992).

Segundo Forte (1996), a sociedade oferece um modelo de família (família pensada), mas as famílias vão estabelecendo um modo de viver cotidiano (família vivida). Cada família tem sua especificidade e esta deve ser considerada em todo o trabalho envolvendo famílias.

Segundo José Filho (2002), a família nuclear moderna surge como um modelo hegemônico "ideal". Em decorrência disso, todos os arranjos familiares que não se encaixam dentro do modelo pré-estabelecido são considerados como "família fora-da-lei", que se escondem por baixo de aparências respeitáveis. Por intermédio dos diversos "espaços de socialização" e/ou diversos "aparelhos ideológicos", as crianças aprendem desde pequenas como "deve" ser uma família.

Segundo esse autor, o que mais predomina no imaginário coletivo da sociedade é a idéia de uma família perfeita: seguidora das tradições, composta de mãe, pai e filhos, coexistindo por laços de aliança e consangüinidade, vivendo numa casa harmoniosa e destinada a ser feliz para toda vida.

Entre as principais características sobre a família nuclear moderna destaca-se:

- casal se une mediante o ritual do casamento civil e religioso; 
- um dos objetivos desse modelo familiar é o de servir à procriação;

- ao homem cabe a função de provedor da família e à mulher, cuidar da educação dos filhos e da tarefa doméstica;

- a reciprocidade de amor afetivo e efetivo entre pais e filhos.

A família ideal faz parte dos padrões culturais da nossa sociedade, pois envolve valores, normas e práticas que se manifestam mediante objetivo e formas de agir e de pensar, sendo estes transmitidos de geração em geração. E como um padrão cultural, faz com que as pessoas façam valer as normas estabelecidas e aqueles que não se enquadram dentro das normas são punidos por mecanismos disciplinares que agridem a individualidade, 0 respeito, a honra e a dignidade das pessoas.

Atualmente, o que está em evidência é a existência de vários arranjos familiares, ou seja:

- famílias com base em uniões livres;

- famílias monoparentais, dirigida só pela mulher ou só pelo homem;

- divorciados gerando novas uniões;

- famílias constituídas por homossexuais;

- mães/adolescentes solteiras que assumem seus filhos, e

- mulheres que decidem ter filhos através da "produção independente", ou seja, sem companheiro estável.

Portanto, o crescimento desses arranjos familiares põe em questão a hegemonia da família nuclear, já que ela se restringe a acompanhar o processo de mudança que vem surgindo em torno da família contemporânea. Desta forma entendemos que a concepção de família está diretamente relacionada aos aspectos culturais e educacionais de cada época.

"Em vez de tentar compreender a família com base na sua composição pura e simplesmente, tomando como modelo a família nuclear, deve-se compreendê-la pelas vias do respeito, da dependência, da reciprocidade e dos valores que estão impregnados na estrutura familiar" (José Filho 2002 p.33).

Frente a isso, é necessário compreender que as várias formas de unidade familiar devem ser consideradas. Neste período de inclusão de novos valores, família corresponde não só a um modelo, mas a vários arranjos familiares que estão surgindo em nossa sociedade, mesmo porque a família é 
o primeiro ponto de referência social que o indivíduo tem, e é dentro dela que ele recebe a proteção e os cuidados necessários para o seu desenvolvimento.

A família é portanto, "um espaço indispensável para a garantia da sobrevivência, do desenvolvimento e da proteção integral dos filhos e demais membros, independente do arranjo familiar ou da forma como vem se estruturando. É a família que propicia os aportes afetivos e sobretudo materiais necessários ao desenvolvimento e bem estar de seus componentes. Ela desempenha um papel decisivo na educação formal e informal e é em seu espaço que são absorvidos os valores éticos e humanitários, onde se aprofundam os laços de solidariedade. É no seu interior que se constroem as marcas entre as gerações e são observados os valores culturais" (Kaloustian 1994 p.11 - 12).

Para Forte (1996) a família, enquanto unidade, é formada por um conjunto de pessoas, cada uma com sua dinâmica interna, configurando uma rede de relações, ou seja, um sistema familiar. Há a dinâmica interna das pessoas e a dinâmica da família, numa interdependência contínua. Em sua dinâmica como um todo, a família sofre influência direta do econômico e do cultural.

A família vai exercer portanto, um papel importante não só na formação da criança, devendo ser percebida como um processo interagente da vida e das trajetórias individuais e co-participantes no processo de reabilitação.

\subsection{1 - Aspectos psicossociais e os distúrbios da comunicação em indivíduos com fissura labiopalatina: a questão familiar.}

O modelo atual biopsicossocial de saúde e doença preconiza que o grau de saúde de uma pessoa depende de uma interação complexa entre fatores psicológicos, biológicos e sociais. Esta conceituação tem importante conseqüência tanto na área de prevenção quanto na de reabilitação (Amaral 1997).

O nascimento de uma criança vai, necessariamente, alterar o equilíbrio anterior da família. Esta pode recuperá-lo em curto, longo prazo ou nunca, verificando-se neste caso, uma situação de crise permanente. Esta crise 
provocada pelo nascimento de uma criança modifica a rotina familiar, e também pode ser uma oportunidade da família repensar e reorganizar os seus padrões interacionais no sentido de integrar este novo membro e restabelecer um novo equilíbrio nas relações familiares (Neves e Paixão 1994).

Freitas (1974), afirma que o nascimento de uma criança com fissura lábio palatina causa um choque maior para os pais, que esperavam por um filho normal. O sentimento de frustração nestes pais é muito intenso, podendo surgir também o sentimento de culpa, por se sentirem responsáveis por tal situação. A criança com fissura já é estigmatizada desde este momento, pois com vergonha, os pais já a escondem e a rejeitam. Por isso, as implicações psicossociais já começam a fazer parte da vida da pessoa com malformação desde o nascimento, estendendo-se por toda a vida.

Amaral (1997) refere que quando um bebê nasce com um defeito facial, os pais vivenciam, imediatamente, uma crise, com a quais lidarão de acordo com suas próprias forças e fraquezas, suas experiências prévias, seus mecanismos estabelecidos para se defender do estresse, e sua filosofia pessoal de vida. Assim, não se pode exatamente prever a resposta dos pais. $O$ que se pode ter certeza é de que este evento terá grandes implicações para eles e para seus filhos e que irão experimentar mágoa e desapontamento, que tenderão a resolver, mais cedo ou mais tarde.

Dessa forma, as implicações psicológicas, oriundas das condições de nascimento, acompanhadas de malformação, que têm origem logo após o nascimento, vão influenciar a maneira como a criança é recebida no seio familiar. O sucesso das primeiras fases do desenvolvimento infantil irá depender da aceitação familiar, uma vez que a família atua como um espelho social, fornecendo à criança informações sobre ela mesma (Cariola 1985).

O nascimento de uma criança com deficiência é uma fonte adicional de estresse no sistema familiar. Determina o aparecimento de um conjunto de problemas específicos, cuja resolução depende da família, que por sua vez dependerá do modo como vai lidar com as situações (Yamada 1998).

Os sentimentos que os pais têm experienciado ao nascer uma criança com malformação têm sido objeto de análise, principalmente do ponto de vista teórico. 
Chinelatto (1994), com base em um estudo do Departamento de Pediatria da Universidade de Cleveland, Ohio, descreve as fases do processo de aceitação da criança malformada. Essas fases não têm um tempo determinado de duração, variam de pessoa para pessoa e a mãe pode começar a viver uma nova fase sem ter encerrado a anterior. Elas não são estanques, mas uma interfere na outra. São elas:

Fase I - é a do choque, da surpresa do nascimento, o impacto.

Fase II - trata-se do período da negação. A mãe diz: "não é possível. Isto não está acontecendo comigo. Eu estou tendo um pesadelo e quando eu acordar vou ver que é mentira".

Fase III - começa a etapa da tristeza, da raiva e da ansiedade. Nessa fase os sentimentos se mesclam, então existe muita depressão. A mãe começa a ter muita ansiedade em relação ao que está por vir, as coisas que ela terá que enfrentar, o que vai acontecer com a criança.

Fase IV - começa o período de reorganização. A família passa a lidar, a assumir o que está acontecendo, os cuidados com a criança. É nessa fase que é avaliado se todo o processo foi vivenciado e se ele foi superado.

Amaral (1997), relata que os sentimentos de choque, ansiedade, perda e culpa são apontados como principais responsáveis pela temporária inabilidade da mãe para lidar instrumentalmente com seus filhos. No início, os pais se preocupam em como lidar com o problema da sobrevivência da criança, alimentação e aparência. Mais tarde, a preocupação será a fala, a dentição e o desenvolvimento social, reagindo às necessidades momentâneas de seus filhos. As mães se queixam de ansiedade e dificuldade para cuidar dos filhos, pois em certos casos de fissuras labiopalatinas raras, a criança apresenta dificuldades alimentares nas primeiras semanas de vida, embora haja, atualmente, uma crescente recomendação para que as mães procurem amamentar seus filhos, tendo em vista benefícios físicos e psicológicos que isto acarreta tanto para a criança como para a mãe.

Segundo Graciano (1988), que estudou as transformações dos sentimentos dos pais e portadores de lesões lábio-palatais em pais 
coordenadores $^{3}$, a maioria referiu-se às situações traumáticas com relação ao nascimento de seus filhos. Os resultados revelaram que, dentre os 39 casos estudados, 92,3\% apresentaram dificuldades de aceitação do bebê ao nascimento. As suas reações expressas em depoimentos revelaram sentimentos de apavoramento, desnorteamento, trauma, difícil aceitação, tristeza, sensibilidade, abalo, dificuldade de encarar com racionalidade, choque, desespero, até angústia, revolta e culpa.

Essas reações foram modificadas principalmente com a oportunidade de tratamento, alegando a maioria não sentir dificuldades atuais em encarar a fissura nos próprios filhos. Foram comuns os depoimentos que expressavam estarem os pais conformados e tranqüilos, visualizando o problema com realidade, como algo com que se tem de conviver e que tem de ser aceito naturalmente, principalmente após encontrarem o recurso especializado - o Hospital de Reabilitação de Anomalias Craniofaciais.

Segundo Oliveira (1992), em uma investigação diagnóstica do Serviço Social em famílias de pacientes casos novos do HRAC, há uma variação em relação às possíveis atribuições da causa do nascimento da criança portadora de fissura. Para os pais, a justificativa decorre da sua própria experiência como místico. Aqueles que possuem um nível de consciência mais próximo da crítica já conseguiram desmistificar o problema e não o encaram com passividade, mas até com certo inconformismo. O problema consegue alterar a dinâmica familiar, porque quanto maior o nível de consciência da família, maior será o seu entendimento quanto à complexidade da malformação e à questão do direito ao tratamento.

Aqueles que possuem um nível de consciência "ingênua" geralmente justificam o problema do nascimento do filho com fissura a causas sobrenaturais como: guardar chave no seio, olhar para um paralítico, ou desígnio de Deus. Não identificam os problemas ocorridos após o nascimento do filho com fissura como alterações na dinâmica familiar, havendo uma forte carga de passividade diante dos problemas e da realidade de um modo geral. Por não possuírem discernimento da complexidade do tratamento, não se

\footnotetext{
${ }^{3}$ Coordenadores: pais e/ou pacientes que representam os próprios pacientes e o Hospital em seu município
} 
intimidam muitas vezes com a probabilidade de outros filhos semelhantes, ou seja, de outra gravidez. Essas pessoas utilizam a mistificação como arma inconsciente para aliviar as dores da realidade que vivem, não conseguindo entender muitas vezes o que vêm a ser os seus direitos.

Nesse estudo, a autora conclui que realmente variam as expectativas, as dificuldades, as ansiedades e as possibilidades das famílias estudadas em relação ao conjunto socioeconômico e cultural familiar (Oliveira 1992).

Um outro estudo realizado pelo Serviço Social do HPRLLP com crianças e adolescentes (Mesquita 1991), cujos sujeitos foram estratificados por idade (7 a 12 anos e acima de 12 anos) e classe social (menos favorecidas e mais favorecidas), constatou que $33 \%$ dos pacientes encontravam dificuldades no relacionamento escolar, apesar do grande índice de apoio e liberação das escolas $(95,1 \%)$ para fins de tratamento; $22,7 \%$ no relacionamento profissional e $18,3 \%$ no relacionamento social.

Estes dados revelam que um percentual significativo de pacientes apresentava problemas psicossociais nas suas atividades cotidianas, especialmente na escola, trabalho e vida social, mas que a maioria, face às oportunidades de tratamento com uma equipe interprofissional e apoio da família, conseguiu superá-los.

Com relação a aparência física, foi verificado por Amaral (1997), maior índice de insatisfação entre os grupos de crianças com fissura do que o manifestado pelo grupo de crianças normais. Estudos com meninas com fissura têm verificado maior ansiedade, menos sucesso escolar, mais infelicidade e maior insatisfação com relação a população em geral (sem fissura). Estes dados sugerem que elas são mais afetadas pelo estigma da deformidade, possivelmente por causa da importância da beleza física para a mulher na sociedade ocidental. Estes estudos parecem não revelar sérias diferenças no auto-conceito de crianças com fissuras, mas não se deve ignorar a evidência de que a fissura tem preponderância nas respostas emocionais e sociais do indivíduo.

$\mathrm{Na}$ tentativa de demonstrar alguns fatores que influenciam no autoconceito de crianças com fissuras, Lansdown (1981) apontou algumas variáveis, tais como: efeitos da classe social, nível educacional dos pais, 
inteligência da criança, grau dos problemas funcionais, tamanho da família, entre outros, e sugeriu que estudos longitudinais sejam realizado a fim de elucidar o assunto.

Mac Gregor (1974) pesquisou durante um quarto de século as implicações psicossociais que acompanham o desfiguramento e a cirurgia reconstrutiva, e apontou a atitude dos pais e das outras pessoas como significante; e a consciência da diferença e as auto-atitudes em relação à elas, como as variáveis mais importantes na formação do auto-conceito das crianças com problemas faciais. $\mathrm{Na}$ verdade, os mitos e estereótipos, a situação específica, a personalidade e o ambiente sócio-cultural são variáveis interrelacionadas à deformação facial.

Amaral (1997) afirma que a reação e atitude dos pais, as relações entre os pais e filhos e as interações da criança com seu ambiente imediato, incluindo irmãos, amigos, colegas, professores e parentes têm sido vistas como importantes variáveis modeladoras do comportamento infantil.

Portanto, os pais ocupam papel muito importante na vida da criança, constituindo-se na fonte reforçadora mais valorizada pela criança, e, conseqüentemente, tendo um papel relevante na sua formação.

Segundo os autores Pertschuck e Whitaker (1985), os pais tratam seus filhos com deformidades faciais como os outros filhos. Embora muitos pais relatassem raiva ao verem seus filhos serem observados por estranhos em lugares públicos, todos negaram qualquer hesitação em levá-los a qualquer ambiente usualmente freqüentado por outros membros da família. Um número bastante representativo de pais entrevistados expressava o desejo de evitar superproteger a criança como participantes de tantas atividades quantas as de seus irmãos normais.

Jones (1984) estudou a avaliação que pais de crianças sem e com fissura faziam da relação social de seus filhos com outras crianças e concluiu que crianças com fissura eram alvo de maior número de respostas negativas da parte de seus pares, do que as crianças normais.

Alguns pais relatam que seus filhos recebem apelidos ou desempenham o "bode expiatório" na escola, são olhados com curiosidade e têm dificuldade de novos contactos sociais. Mas, uma vez conhecida e aceita pelo grupo, a 
criança parece desenvolver satisfatoriamente suas relações com parentes, amigos da rua e colegas da classe.

Para Amaral (1997), ao lado da família, o conjunto de variáveis que terá maior influência sobre a vida da criança será a escola. Para a criança portadora de deformidade facial, será a primeira e mais importante experiência sistemática fora do ambiente do lar. A escola será o palco onde terá de enfrentar novos relacionamentos, será olhada, julgada, avaliada e sua aparência física será uma variável importante nestes julgamentos.

Pouca informação existe no que diz respeito ao efeito de estigmas físicos no comportamento em sala de aula e no rendimento escolar. A criança com desfiguramento facial apresenta, muitas vezes, problemas fonoaudiológicos associados, e estas características podem influenciar a percepção dos professores, a qual, por sua vez, pode afetar o desenvolvimento da criança em sala de aula.

Amaral (1997), concluiu em seus estudos que pessoas com fissuras labiopalatinas parecem não se diferenciar basicamente em termos de desenvolvimento da personalidade de seus pares normais a ponto de se caracterizarem como um grupo típico, baseado no fato exclusivo de terem uma fissura. Na verdade, este tipo de deformidade facial manifesta-se de múltiplas formas, tornando difícil a formação de grupos homogêneos para fins de estudo sistemáticos. O que parece ocorrer é que a fissura traz para o indivíduo uma série de contingências físicas, psicológicas, afetivas e sociais e que produzem conseqüências, manifestadas em algumas características comumente encontradas no grupo, como: redução no auto-conceito, maior dependência dos pais, isolamento, esquiva de novas relações, redução do "input" verbal, dificuldades verbais, entre outras.

A equipe interdisciplinar responsável pelo processo de reabilitação deve estar atenta a todas as fases de desenvolvimento, desde o nascimento até a fase adulta, a fim de que se possa, junto com a família, o cliente e a própria sociedade, alcançar com sucesso os objetivos da tarefa de reabilitar, favorecendo as condições para o desenvolvimento das capacidades físicas, psicológicas, afetivas e sociais. 
Conforme Paynter (1991) os pais devem receber informações corretas, perceber e sensibilizar-se da importância de sua postura participativa, pois representam o ponto principal de todo o tratamento.

Incluindo os pais nas decisões e planejamento de tratamento, a equipe pode ganhar seu apoio e cooperação, pois a família mostra exercer poderosa influência em seus membros, o que pode resultar em recurso significativo de tratamento de acordo com Pannbacker e Scheuerle (1993).

Segundo Altmann et al (1997 p. 367) "a família e principalmente os pais de uma criança com fissura labiopalatina têm um papel fundamental no seu desenvolvimento social. A atitude dos pais frente aos problemas que a criança irá enfrentar influencia o seu comportamento perante a sociedade e, conseqüentemente, a visão que essa mesma sociedade terá de suas potencialidades".

Entendemos que, como o desenvolvimento pessoal e intelectual são influenciados pela reação e atitude dos pais, interação da criança com o seu ambiente social, cabe aos pais e profissionais colaborar no processo de inclusão social das pessoas com fissura labiopalatinas.

Por inclusão social, entendemos com base em Sassaki (1997), o processo pelo qual a sociedade se adapta para poder incluir, em seus sistemas sociais gerais, pessoas com necessidades especiais e, simultaneamente, estas se preparam para assumir seus papéis na sociedade. A inclusão social constitui, então, um processo bilateral no qual as pessoas, ainda excluídas, e a sociedade buscam, em parceria, equacionar problemas, decidir sobre soluções e efetivar a equiparação de oportunidades para todos. 


\subsection{2 - O estudo social como instrumento estratégico de conhecimento da realidade social: aspectos sociais, econômicos, culturais e familiares.}

A necessidade de prestar informações sobre a condição socioeconômica dos pacientes tem sido uma das constantes demandas do serviço social da área hospitalar. Profissionais da equipe interdisciplinar da saúde necessitam conhecer as condições de vida do paciente em seu meio familiar e na sociedade, seja para um tratamento clínico ou cirúrgico, medicamentos, de cuidados gerais e até mesmo no manejo das emoções que envolvem o estado de doença (Camargo 2000).

Cabe ao Serviço Social, portanto, a responsabilidade em fornecer à equipe interdisciplinar, uma visão da realidade socioeconômica e cultural do paciente, interpretando o diagnóstico das suas condições de vida, colaborando no planejamento do tratamento com base na realidade social de cada um (Graciano et al 1999).

Para tanto, utiliza-se do estudo social, que segundo a Lei $n^{\circ}$ 8662/93 é de competência do assistente social: "realizar estudo socioeconômicos com os usuários para fins de benefícios e serviços sociais junto a órgãos da administração pública direta e indireta, empresas privadas e outras entidades" (Brasil 2004d).

Segundo Fávero (2003), o estudo social é um processo metodológico específico do Serviço Social, que tem por finalidade conhecer com profundidade, e de forma crítica, uma determinada situação ou expressão da questão social, objeto da intervenção profissional. É baseado no contexto familiar, tendo como finalidade subsidiar decisões e ações, a respeito da realidade sócio familiar de cada indivíduo e família e das questões sociais que afetam suas relações sociais, especialmente nos aspectos socioeconômicos e culturais (Graciano et al 1999).

O estudo socioeconômico é realizado mediante um instrumental, que é definido como "o conjunto articulado de instrumentos e técnicas que permitem a operacionalização da ação profissional. Nessa concepção, é possível atribuir-se ao instrumento a natureza de estratégia ou tática, por meio da qual se realiza a 
ação, e à técnica, fundamentalmente a habilidade no uso do instrumental" (Martinelli e Koumrouyan 1994 p.137). É portanto um conjunto de procedimentos utilizados para conhecer e intervir, numa determinada realidade humano social.

Segundo Sarmento (1994) os instrumentais e técnicas, permitem a operacionalização da proposta de ação, pois é por meio deles que contactamos com a realidade, conhecendo-a para, através deles intervir.

O Serviço Social do HRAC utiliza-se de uma metodologia própria para o estudo socioeconômico, que compreende os seguintes indicadores: situação econômica da família, número de membros, escolaridade, ocupação e habitação, sistematizados em uma tabela com seis estratificações: Baixa Inferior (BI), Baixa Superior (BS), Média Inferior (MI), Média (M), Média Superior (MS), e Alta (A) (Graciano et al 1999) (anexo 1).

Essa metodologia implantada pelo Serviço Social do HRAC, (Graciano 1980 e Graciano et al 1996 e 1999) foi objeto de pesquisa em uma amostra de 3059 casos, (Graciano et al 1999 e 2001), verificando-se uma concordância de $98,8 \%$ por parte dos profissionais com os resultados da classificação obtida, demonstrando, assim, a viabilidade e eficácia deste instrumental.

A estratificação social, segundo Gurvitch, (1996) citado por Gohn (1999 p.37), diz respeito "à classificação dos indivíduos e grupos sociais segundo determinadas qualidades ou atributos, separando-os nas classes sociais correspondentes. Os principais atributos utilizados para essa separação são: educação (nível de escolaridade) renda, status social, profissão e ocupação, origem social etc".

De acordo com dados fornecidos pelo Centro de Processamento de Dados (CPD) do HRAC, quanto a estratificação social de 30.169 pacientes matriculados, com estudos sociais informatizados até março de 2005 , estão assim distribuídos: BI (27,8\%); BS (55,3\%); MI (14,0\%); M (2,6\%); MS (0,2\%) e A $(0,01 \%)$. As características de cada estratificação social podem ser visualizadas no (anexo 2), permitindo a sua configuração socioeconômica.

Além da classificação socioeconômica, o estudo social engloba outras questões sociais enfocando as relações sociais na família, trabalho, escola e comunidade. Aborda ainda o conhecimento e acesso aos recursos 
governamentais, institucionais e municipais para a reabilitação visando, se necessário, a intervenção social.

O estudo social, realizado pela equipe de assistentes sociais do HRAC, tem servido de ponto de partida para o aprofundamento dos aspectos psicossociais e familiares dos indivíduos participantes desta pesquisa. 


\section{OBJETIVOS.}

Partindo dos questionamentos se existem diferenças significativas entre os aspectos psicossociais, econômicos e familiares de indivíduos com e sem distúrbios da comunicação, definimos os seguintes objetivos para este trabalho:

\section{1 - Objetivo geral.}

- Caracterizar e analisar os aspectos psicossociais e familiares de indivíduos com e sem distúrbios da comunicação decorrentes da fissura labiopalatina.

\section{2 - Objetivos específicos.}

- levantar o perfil socioeconômico e geográfico;

- conhecer o histórico e a dinâmica familiar, as relações sociais e o nível de participação no tratamento;

- identificar os recursos organizacionais e comunitários nos municípios de origem para apoio ao processo de reabilitação, avaliando a satisfação dos usuários;

- constatar as intercorrências no seguimento do tratamento fonoaudiológico na cidade de origem;

- estudar as interrelações entre os diferentes estratos socioeconômicos e o desenvolvimento da fala (pacientes com e sem distúrbios da comunicação). 


\section{MATERIAL E MÉTODO}




\section{MATERIAL E MÉTODO.}

Para o desenvolvimento deste projeto contamos inicialmente com a colaboração da Coordenadoria Geral do Projeto Flórida do HRAC/USP, que disponibilizou a relação dos sujeitos com e sem distúrbios da comunicação, a partir do Banco de Dados do Projeto Flórida, com o compromisso de nos apoiar no desenvolvimento do projeto nas questões específicas da área de fonoaudiologia.

Com o objetivo de assegurar que o diagnóstico e a consistência dos distúrbios da comunicação fossem avaliados por meio de amostras de fala fidedignas e estabelecidas num período adequado do desenvolvimento da fala destes pacientes, consideramos somente os pacientes com idade acima de 4 anos, por apresentarem maiores possibilidades de cooperarem e submeteremse a avaliação da fala. Ressaltamos que o diagnóstico dos distúrbios da comunicação dos pacientes incluídos no universo desta pesquisa foi realizado pela equipe de fonoaudiólogos do Projeto Flórida de acordo com os protocolos estabelecidos no projeto e no HRAC. Os dados quanto a presença ou não de distúrbios da comunicação decorrentes da disfunção velofaríngea, de alterações dento-oclusais ou de atrasos desenvolvimentais foram obtidos do banco de dados do projeto.

Portanto, o universo desta pesquisa teve como sujeitos, pacientes acima de 4 anos participantes do "Projeto Flórida", totalizando 211 casos, caracterizados tanto em suas similaridades como em suas especificidades, em 2 grupos:

Grupo I (GI) - grupo de indivíduos com distúrbios da comunicação decorrentes da disfunção velofaríngea, alterações dento-oclusais e/ou atrasos no desenvolvimento da fala - 96 sujeitos;

Grupo II (GII) - grupo de indivíduos sem distúrbios da comunicação 115 sujeitos.

O tipo de amostra foi não probabilística - por acessibilidade - tipologia esta definida segundo Gil (1989 p.97) como aquela em que: "o pesquisador seleciona os elementos a que tem acesso, admitindo que estes possam, de 
alguma forma, representar o universo. Aplica-se este tipo de amostragem em estudos exploratórios ou qualitativos, onde não é requerido elevado nível de precisão".

Assim, após a avaliação e aprovação pela Banca Examinadora da PréQualificação em 15/03/04 (anexo 3) e pelo Comitê de Ética em Pesquisa do Hospital de Reabilitação de Anomalias Craniofaciais - HRAC-USP em 25/08/04 (anexo 4), solicitamos à Secretaria do Projeto Flórida o agendamento com o Serviço Social, em nome da pesquisadora, dos pacientes de ambos os grupos e, com retornos previstos no HRAC no período de março a maio de 2005, como critério de acessibilidade para a constituição de uma amostra significativa que representasse o universo.

A amostra foi constituída de 38 indivíduos, (18,0\% do universo) distribuídos respectivamente nos dois grupos: GI - 20 sujeitos e Gll - 18 sujeitos.

A tipologia do estudo foi exploratória, por permitir ao "investigador aumentar sua experiência em torno de determinado problema" e descritiva, por pretender "descrever com exatidão os fatos e fenômenos de determinada realidade" (Trivinos 1995 p. 105). A pesquisa descritiva engloba a bibliográfica, a documental e a de campo (Barros e Lehfeld 2000).

$\mathrm{Na}$ pesquisa documental, os dados coletados dos prontuários foram: demográficos, socioeconômicos, geográficos, como também informações obtidas por meio de relatórios referentes aos estudos sociais fornecidos pelo Centro de Processamento de Dados (CPD) e do Projeto Flórida.

$\mathrm{Na}$ pesquisa de campo, o instrumental de coleta de dados foi o formulário com perguntas abertas e fechadas (anexo 5) aplicado por meio de entrevista com o responsável pelo paciente. Realizamos um pré-teste com o objetivo de verificar a necessidade de alterações e, após reajustes finais, obteve-se o instrumento em sua forma definitiva.

Mediante um compromisso ético, os participantes foram esclarecidos previamente quanto aos objetivos e finalidades da pesquisa, sigilo, privacidade das informações, preservação da identidade no caso de divulgação dos resultados e a respeito da liberdade de participação. 
Com a respectiva aprovação, mediante assinatura do termo de consentimento livre e esclarecido (anexo 6), os dados foram coletados por meio de entrevistas com duração média de 40 minutos, realizadas individualmente, quando somente um dos pais estava presente ou, quando possível, com a presença do casal.

As categorias para a coleta e análise dos dados foram eleitas e agrupadas em 4 eixos temáticos:

Eixo 1 - Estratificação social: situação econômica, número de membros, escolaridade, habitação e ocupação;

Eixo 2 - Histórico e dinâmica familiar: situação conjugal e religiosa; planejamento familiar, preocupações quanto a reincidência; conhecimento sobre a ocorrência da fissura; reações, sentimentos e repercussões; causas, denominações e significados atribuídos;

Eixo 3 - Relações sociais do indivíduo e família: dificuldades/facilidades de comunicação e relacionamento profissional, escolar, social e familiar;

Eixo 4 - Tratamento reabilitador, recursos organizacionais e comunitários: concepção, expectativas, atitudes, orientações, acesso aos recursos, intercorrências clínico-sociais no seguimento do tratamento, participação e satisfação.

Optamos pelo método dialético, entendido como aquele que "...pensa a relação da quantidade como uma das qualidades dos fatos e fenômenos. Busca encontrar, na parte, a compreensão e a relação com o todo; e a interioridade e exterioridade como constitutivas dos fenômenos" (Minayo 1994 p.24-25).

Para Lakatos e Marconi (1991) o método dialético estuda os fatos e fenômenos dentro de um contexto social que configura a totalidade. Complementa Chizzotti (1995 p.80) que o método dialético "insiste na relação dinâmica entre o sujeito e o objeto, no processo de conhecimento, valoriza a contradição, dinâmica do fato observado e a atividade criadora do sujeito que observa, as oposições contraditórias entre o todo e a parte e os vínculos do saber e do agir com a vida social dos homens".

Tratou-se de uma pesquisa com abordagem quanti-qualitativa, pois segundo Chizzotti (1995 p. 52), "as pesquisas quantitativas prevêem a 
mensuração de variáveis pré-estabelecidas, procurando verificar e explicar sua influência sobre outras variáveis, mediante a análise da freqüência de incidências e de correlações estatísticas". "As pesquisas qualitativas fundamentam-se em dados coligidos nas interações interpessoais, na coparticipação das situações dos informantes, analisadas a partir da significação que estes dão aos seus atos". Procuram compreender as experiências que os sujeitos têm, as representações que formam e os conceitos que elaboram, partindo do princípio que todos os sujeitos permanecem únicos e todos os seus pontos de vista são relevantes. Portanto, o pesquisador participa, compreende e interpreta a realidade pesquisada.

Minayo (1994) ressalta que a diferença entre qualitativo e quantitativo é de natureza pois enquanto os cientistas sociais trabalham com estatística, apreendem dos fenômenos apenas a região visível, concreta..., a abordagem qualitativa se aprofunda no mundo dos significados das ações e relações humanas.

Para a apresentação e análise dos dados, observamos as seguintes etapas: definição de categorias; tabulação mediante a distribuição de freqüências (absolutas e relativas) em tabelas e figuras, e análise final.

Para análise estatística das variáveis entre os grupos, foram utilizados o Teste do Qui-quadrado $\left(x^{2}\right)$ e o Teste Exato de Fisher, sendo adotado nível de significância de $5 \%(p<0,05)$. Esta análise foi realizada por profissional da área de estatística da Faculdade de Odontologia de Bauru/USP.

A apresentação e discussão dos resultados a seguir visam a articulação entre os dados e os referenciais teóricos, respondendo às questões da pesquisa com base nos objetivos, promovendo as relações entre o concreto e o abstrato, o geral e o particular, a teoria e a prática (Gil 1989 e Minayo 1994). 


\section{RESULTADOS E DISCUSSÃO.}

Com base nos dados obtidos nas entrevistas e documentos, apresentamos os resultados referentes ao estudo dos aspectos psicossociais e familiares dos indivíduos com distúrbios da comunicação decorrentes da disfunção velofaríngea, alterações dento-oclusais e/ou atraso no desenvolvimento da fala - 20 sujeitos $\mathrm{GI}$, e de indivíduos sem distúrbios da comunicação - 18 sujeitos Gll, totalizando 38 indivíduos na amostra (GI + GII).

A apresentação e discussão dos dados ocorrerá de forma descritiva e estatística dos conteúdos, em categorias agrupadas por eixos temáticos, considerando-se tanto a totalidade da amostra como os grupos individualmente.

Primeiramente faz-se necessário uma caracterização do perfil dos indivíduos quanto ao informante, gênero, faixa etária e procedência, (Tabela 1).

Tabela 1 - Perfil dos indivíduos segundo informante, gênero, faixa etária e procedência

\begin{tabular}{|c|c|c|c|c|c|c|}
\hline \multirow{2}{*}{ Categorias } & \multicolumn{2}{|c|}{ G I } & \multicolumn{2}{|c|}{ G II } & \multicolumn{2}{|c|}{$\frac{\text { Total }}{(\mathrm{GI}+\mathrm{GII})}$} \\
\hline & $\bar{n}$ & $\%$ & $\bar{n}$ & $\%$ & $\mathbf{n}$ & $\%$ \\
\hline \multicolumn{7}{|l|}{ Informante: } \\
\hline Pais & 1 & 5,0 & 2 & 11,1 & 3 & 7,9 \\
\hline Mãe & 15 & 75,0 & 15 & 83,3 & 30 & 78,9 \\
\hline Pai & 3 & 15,0 & - & - & 3 & 7,9 \\
\hline Outros & 1 & 5,0 & 1 & 5,6 & 2 & 5,3 \\
\hline TOTAL & 20 & 100,0 & 18 & 100,0 & 38 & 100,0 \\
\hline \multicolumn{7}{|l|}{ Gênero: } \\
\hline Masculino & 12 & 60,0 & 10 & 55,6 & 22 & 57,9 \\
\hline Feminino & 8 & 40,0 & 8 & 44,4 & 16 & 42,1 \\
\hline TOTAL & 20 & 100,0 & 18 & 100,0 & 38 & 100,0 \\
\hline \multicolumn{7}{|l|}{ Faixa etária: } \\
\hline 4 e 5 anos & 1 & 5,0 & 5 & 27,8 & 6 & 15,8 \\
\hline 6 e 7 anos & 10 & 50,0 & 7 & 38,9 & 17 & 44,7 \\
\hline 8 e 9 anos & 9 & 45,0 & 6 & 33,3 & 15 & 39,5 \\
\hline TOTAL & 20 & 100,0 & 18 & 100,0 & 38 & 100,0 \\
\hline
\end{tabular}


Continuação

\begin{tabular}{llrrrrrr}
\hline Região/Estado: & & & & & & & \\
Sul (PR, SC) & Sub - total & 3 & 15,0 & 2 & 11,1 & 5 & 13,2 \\
Sudeste (MG, SP, RJ, ES) & Sub - total & 11 & 55,0 & 14 & 77,7 & 25 & 65,8 \\
Centro-Oeste(DF, MS, MT,GO) & Sub - total & 5 & 25,0 & 1 & 5,6 & 6 & 15,8 \\
Norte (RO) & Sub - total & - & - & 1 & 5,6 & 1 & 2,6 \\
Nordeste (RN) & Sub - total & 1 & 5,0 & - & - & 1 & 2,6 \\
& TOTAL & $\mathbf{2 0}$ & $\mathbf{1 0 0 , 0}$ & $\mathbf{1 8}$ & $\mathbf{1 0 0 , 0}$ & $\mathbf{3 8}$ & $\mathbf{1 0 0 , 0}$ \\
\hline Distância em Km: & & & & & & & \\
0 a 500 km & 9 & 45,0 & 11 & 61,1 & 20 & 52,6 \\
501 a 1000 km & 10 & 50,0 & 4 & 22,2 & 14 & 36,9 \\
1001 a 1500 km & & - & - & 1 & 5,6 & 1 & 2,6 \\
1501 km acima & 1 & 5,0 & 2 & 11,1 & 3 & 7,9 \\
TOTAL & $\mathbf{2 0}$ & $\mathbf{1 0 0 , 0}$ & $\mathbf{1 8}$ & $\mathbf{1 0 0 , 0}$ & $\mathbf{3 8}$ & $\mathbf{1 0 0 , 0}$ \\
\hline
\end{tabular}

Analisando os dados com relação ao informante, constatamos na totalidade da amostra, uma maior concentração na figura materna $(78,9 \%)$, em função da mãe assumir, na maioria das situações, o acompanhamento do tratamento.

Com relação ao gênero, o maior índice é masculino com 57,9\% e o feminino com $42,1 \%$, confirmando a literatura, pois segundo Souza Freitas (1974), há uma diferença estatística entre os gêneros e tipos de fissuras, sendo que as do lábio e palato são mais freqüentes no gênero masculino, e as de palato isoladamente, no feminino.

Na faixa etária atual, considerando que o "Projeto Flórida" iniciou-se em 1996, selecionando crianças de até 6 meses de idade, hoje, decorridos 10 anos, temos uma representatividade em várias faixas etárias (até 9 anos), com maior incidência na de 6 e 7 anos (44,7\%) para a totalidade da amostra.

A representatividade nas diferentes faixas ocorre, portanto, em virtude da característica longitudinal do "Projeto Flórida", e, do tratamento que acompanha o desenvolvimento das crianças operadas de lábio e palato, desde o nascimento, podendo se estender até a idade adulta, visando a reabilitação não só estética mas funcional e psicossocial.

$\mathrm{Na}$ categoria procedência, a totalidade da amostra apresenta uma maior concentração na região Sudeste $(65,8 \%)$, seguida da Centro-oeste $(15,8 \%)$. 
Quanto a distância em km da cidade de origem até o HRAC, o maior índice $(52,6 \%)$ está na faixa de até $500 \mathrm{~km}$, portanto mais próximo do local de tratamento, seguido de 501 a $1000 \mathrm{Km}(36,9 \%)$.

Estes dados refletem a situação do HRAC, que apresenta maior concentração de pacientes destas regiões: Sudeste $(62,0 \%)$, Sul $(16,3 \%)$ e Centro-Oeste $(11,4 \%)$, bem como do Projeto Flórida: Sudeste (59,3\%), Sul $(18,6 \%)$ e Centro-Oeste $(14,4 \%)$ (Graciano et al 2004$)$.

A análise estatística, adotando o Teste Qui-quadrado $\left(x^{2}\right)$, mostrou que, tanto em relação a região de procedência $(p=0,274)$, e à questão que se refere a distância $(p=0,260)$, não apresentaram diferenciação significativa entre os grupos.

\section{1 - Estratificação social - Eixo 1.}

Neste eixo, procuramos identificar a amostra considerando dados da família, segundo a estratificação social e suas características quanto aos indicadores: situação econômica, número de membros, escolaridade, habitação e ocupação.

As informações sobre estes dados estão especificados na tabela 2 e nas figuras 6,7 e 8 .

Tabela 2 - Estratificação social

\begin{tabular}{|c|c|c|c|c|c|c|}
\hline \multirow{2}{*}{ Estratificação social } & \multicolumn{2}{|c|}{ G I } & \multicolumn{2}{|c|}{ G II } & \multicolumn{2}{|c|}{$\frac{\text { Total }}{(\mathrm{GI}+\mathrm{GII})}$} \\
\hline & $\mathbf{n}$ & $\%$ & $\bar{n}$ & $\%$ & $\mathbf{n}$ & $\%$ \\
\hline Baixa Inferior (BI) & 7 & 35,0 & 9 & 50,0 & 16 & 42,1 \\
\hline Baixa Superior (BS) & 10 & 50,0 & 7 & 38,8 & 17 & 44,8 \\
\hline Sub-total (Baixas) & 17 & 85,0 & 16 & 88,8 & 33 & 86,9 \\
\hline Média Inferior (MI) & 2 & 10,0 & 2 & 11,2 & 4 & 10,5 \\
\hline Média (M) & 1 & 5,0 & - & - & 1 & 2,6 \\
\hline Sub-total (Médias) & 3 & 15,0 & 2 & 11,2 & 5 & 13,1 \\
\hline TOTAL & 20 & 100,0 & 18 & 100,0 & 38 & 100,0 \\
\hline
\end{tabular}

$\mathrm{Na}$ estratificação social, predominou na totalidade da amostra as classificações Baixas (86,9\%), em comparação às Médias (13,1\%). 
Ao analisarmos separadamente os grupos, observamos que, no Gl houve maior concentração na Baixa Superior $(50,0 \%)$ em comparação com a Baixa Inferior (35,0\%), e nas Médias, houve predominância da Média Inferior $(10,0 \%)$.

No Gll, observamos que o índice foi maior para a estratificação Baixa Inferior (50,0\%), em comparação com a Baixa Superior (38,8\%), sendo que na Média só identificamos indivíduos na categoria Média Inferior $(11,2 \%)$.

A concentração, em ambos os grupos, nos estratos Baixos refletem tanto a realidade dos indivíduos participantes do "Projeto Flórida" (82,2\% pertencem aos estratos baixos), bem como do HRAC e da realidade brasileira. No HRAC o índice desses estratos baixos somam $72,4 \%{ }^{4}$ e na população do Brasil, 71,0\% (Critério de Classificação Econômica Brasil 2003). O nível de pobreza é, portanto, de desigualdade social vivenciado pela população brasileira, e confirmado com a grande concentração de renda do país, em que, apenas $1 \%$ da população brasileira se apropria de $53 \%$ do estoque acumulado de riquezas, tendo o Brasil cerca de 36 milhões de pessoas vivendo nas cidades abaixo da linha de pobreza absoluta (Benjamim 1997).

Para podermos conhecer melhor as características dos diferentes estratos sociais, apresentaremos a seguir a configuração dos grupos, mediante os índices mais significativos de cada indicador: situação econômica familiar, número de membros residentes na família, escolaridade, ocupação, e habitação, conforme figura $6(\mathrm{Gl})$, figura 7 (GII) e figura $8(\mathrm{GI}+\mathrm{GII})$.

\begin{tabular}{|c|c|c|c|c|c|c|}
\hline \multirow{2}{*}{ Indicadores } & \multirow{2}{*}{$\begin{array}{c}\text { Situação } \\
\text { econômica }\end{array}$} & \multirow{2}{*}{$\begin{array}{l}\text { Membros } \\
\text { (pessoas) }\end{array}$} & \multirow{2}{*}{ Escolaridade } & \multicolumn{2}{|c|}{ Habitação } & \multirow{2}{*}{ Ocupação } \\
\hline & & & & Condição & Situação & \\
\hline Estratificação & & & & & & \\
\hline $\begin{array}{l}\text { Baixa } \\
\text { Inferior: } 7\end{array}$ & $\begin{array}{l}\text { de } 1 / 2 \text { a } 2 \text { SM: } \\
85,7 \%\end{array}$ & 4 a $6: 57,1 \%$ & $\begin{array}{l}\text { Prim. Inc. } \\
57,1 \% \\
\text { Gin. Inc. } \\
42,8 \%\end{array}$ & $\begin{array}{l}\text { Própria: } 42,8 \% \\
\text { Cedida: } 42,8 \%\end{array}$ & $\begin{array}{l}\text { Regular: } \\
57,1 \%\end{array}$ & $\begin{array}{l}\text { Trab. Rur. } \\
\text { Assal.: } 57,1 \%\end{array}$ \\
\hline
\end{tabular}

\footnotetext{
${ }^{4}$ Dados fornecidos pelo Centro de Processamento de Dados (CPD) do HRAC em dez./2005.
} 
Continuação

\begin{tabular}{|l|l|l|l|l|l|l|}
\hline $\begin{array}{l}\text { Baixa } \\
\text { Superior: } 10\end{array}$ & $\begin{array}{l}\text { de } 2 \text { a } 4 \text { SM: } \\
70,0 \%\end{array}$ & 4 a 6: 80,0\% & $\begin{array}{l}\text { Col. Comp. } \\
50,0 \%\end{array}$ & $\begin{array}{l}\text { Cedida: 40,0\% } \\
\text { Alugada: } \\
30,0 \%\end{array}$ & $\begin{array}{l}\text { Regular: } \\
30,0 \% \\
\text { Insatisfatória: } \\
30,0 \%\end{array}$ & $\begin{array}{l}\text { Trab. } \\
\text { Assal/Prod.: } \\
60,0 \%\end{array}$ \\
Trab. Aut.: \\
$\begin{array}{l}\text { Própria: } 30,0 \% \\
40 \%\end{array}$
\end{tabular}

Estudo baseado em pacientes com dados fornecidos pelo CPD do HRAC - em junho/2005.

Total de Casos: 20

Legenda:

SM: salário mínimo

Prim. Inc.: primário

incompleto

Gin. Inc.: ginasial incompleto

Col. Comp.: colegial completo Trab. Assal/Prod:: trabalhador assalariado/produção de bens e serviços

Trab. Aut.: trabalhador autônomo
Trab. Assal. Adm. Téc-Cien.: trabalhador assalariado administrativo técnicocientífico

Trab. Rur. Assal.: trabalhador rural assalariado

\section{Figura 6 - Configuração dos estratos sociais - GI}

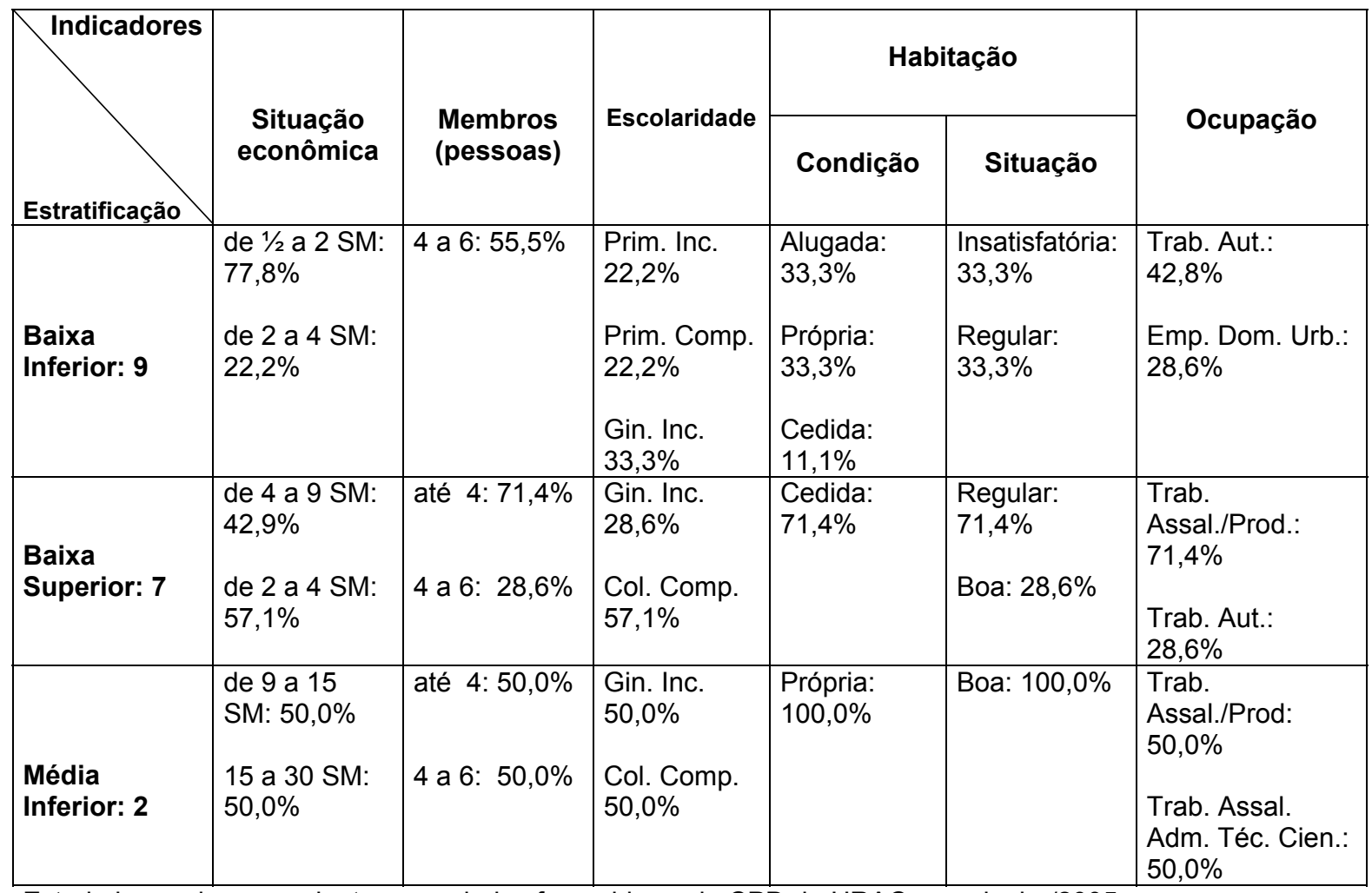

Estudo baseado em pacientes com dados fornecidos pelo CPD do HRAC - em junho/2005.

Total de casos: 18

Legenda:

SM: salário mínimo

Prim. Inc.: primário incompleto

Prim. Comp.: primário completo

Emp. Dom. Urb.: empregado

doméstico urbano
Gin. Inc.: ginasial incompleto

Col. Comp.: colegial completo

Trab. Assal.: trabalhador

assalariado /produção de bens

e serviços
Trab. Assal. Adm. Téc. Cien.: trabalhador assalariado administrativo técnico-científico

Trab. Aut.: trabalhador autônomo

\section{Figura 7 - Configuração dos estratos sociais - GII}




\begin{tabular}{|c|c|c|c|c|c|c|}
\hline \multirow{3}{*}{ Estratificaçãd } & \multirow{2}{*}{$\begin{array}{l}\text { Situação } \\
\text { econômica }\end{array}$} & \multirow{2}{*}{$\begin{array}{l}\text { Membros } \\
\text { (pessoas) }\end{array}$} & \multirow{2}{*}{ Escolaridade } & \multicolumn{2}{|c|}{ Habitação } & \multirow{3}{*}{ Ocupação } \\
\hline & & & & Condição & Situação & \\
\hline & & & & & & \\
\hline $\begin{array}{l}\text { Baixa } \\
\text { Inferior: } 16\end{array}$ & $\begin{array}{l}\text { de } 1 / 2 \text { a } 2 \text { SM: } \\
81,2 \% \\
\text { de } 2 \text { a } 4 \text { SM: } \\
12,5 \%\end{array}$ & 4 a $6: 56,2 \%$ & $\begin{array}{l}\text { Prim. Inc. } \\
37,5 \% \\
\text { Gin. Inc.: } \\
\text { 37,5\% } \\
\text { Col. Comp.: } \\
\text { 12,5\% }\end{array}$ & $\begin{array}{l}\text { Própria: } \\
43,7 \% \\
\\
\text { Cedida: } \\
25,0 \% \\
\text { Alugada: } \\
18,7 \%\end{array}$ & $\begin{array}{l}\text { Regular: } \\
43,8 \% \\
\\
\text { Insatisfatória } \\
31,2 \%\end{array}$ & $\begin{array}{l}\text { Trab. } \\
\text { Assal/Prod.: } \\
28,6 \% \\
\\
\text { Trab. Rur. } \\
\text { Assal.: } \\
35,8 \% \\
\\
\text { Emp. Dom. } \\
\text { Urb.: } 21,4 \% \\
\end{array}$ \\
\hline $\begin{array}{l}\text { Baixa } \\
\text { Superior: } 17\end{array}$ & $\begin{array}{l}\text { de } 2 \text { a } 4 \text { SM: } \\
64,7 \% \\
\text { de } 4 \text { a } 9 \text { SM: } \\
23,5 \%\end{array}$ & $\begin{array}{l}\text { até } 4: 41,2 \% \\
4 \text { a } 6: 47,0 \%\end{array}$ & $\begin{array}{l}\text { Gin. Inc.: } \\
23,5 \% \\
\text { Col. Comp.: } \\
52,9 \%\end{array}$ & $\begin{array}{l}\text { Cedida: } \\
52,9 \% \\
\text { Alugada: } \\
23,5 \% \\
\\
\text { Própria: } \\
23,5 \% \\
\end{array}$ & $\begin{array}{l}\text { Regular: } \\
41,2 \% \\
\text { Boa: } 35,2 \%\end{array}$ & $\begin{array}{l}\text { Trab. } \\
\text { Assal./Prod.: } \\
64,7 \% \\
\\
\text { Trab. Aut.: } \\
35,3 \%\end{array}$ \\
\hline $\begin{array}{l}\text { Média } \\
\text { Inferior: } 4\end{array}$ & $\begin{array}{l}\text { de } 9 \text { a } 15 \text { SM: } \\
75,0 \% \\
\text { de } 15 \text { à } 30 \text { SM: } \\
25,0 \%\end{array}$ & $\begin{array}{l}\text { até } 4: 50,0 \% \\
4 \text { a 6: } 50,0 \%\end{array}$ & $\begin{array}{l}\text { Gin. Inc.: } \\
50,0 \% \\
\text { Gin. Comp.: } \\
25,0 \% \\
\text { Col. Comp: } \\
25,0 \% \\
\end{array}$ & $\begin{array}{l}\text { Própria: } \\
75,0 \%\end{array}$ & $\begin{array}{l}\text { Boa: } 50,0 \% \\
\text { Regular: } \\
25,0 \% \\
\\
\text { Insatisfatória } \\
25,0 \%\end{array}$ & $\begin{array}{l}\text { Trab. } \\
\text { Assal./Prod.: } \\
75,0 \% \\
\\
\text { Trab. Assal. } \\
\text { Adm. Téc. } \\
\text { Cien.: } 25,0 \%\end{array}$ \\
\hline Média: 1 & $\begin{array}{l}\text { de } 30 \text { a } 60 \text { SM: } \\
100,0 \%\end{array}$ & $\begin{array}{l}\text { até 04: } \\
100,0 \%\end{array}$ & $\begin{array}{l}\text { Col. Comp.: } \\
100,0 \%\end{array}$ & $\begin{array}{l}\text { Própria: } \\
100,0 \%\end{array}$ & $\begin{array}{l}\text { Boa: } \\
100,0 \%\end{array}$ & $\begin{array}{l}\text { Trab. Assal. } \\
\text { Adm. Téc. } \\
\text { Cien.: } \\
100,0 \%\end{array}$ \\
\hline
\end{tabular}

Estudo baseado em pacientes com dados fornecidos pelo CPD do HRAC - em junho/2005.

Total de casos: 38

Legenda:

SM: salário mínimo

Prim. Inc.: primário incompleto

Gin. Inc.: ginasial incompleto

Col. Comp.: colegial completo

Trab. Assal/Prod.: trabalhador assalariado

/produção de bens e serviços

Trab. Assal. Adm. Téc. Cien.: trabalhador

assalariado administrativo técnico-

científico

Emp. Dom. Urb.: empregado

doméstico urbano

\section{Figura 8 - Configuração dos estratos sociais - GI + GII}

Trab. Rur. Assal.: trabalhador rural assalariado

Trab. Aut.: trabalhador autônomo

Os resultados gerais obtidos na configuração dos estratos sociais, na totalidade das amostras (figura 8), permitiram compor a seguinte caracterização, para o total de sujeitos $(G|+G| l=38)$, cujas características se mantém nos grupos individuais $(\mathrm{Gl}=20$ e $\mathrm{GI}=18$ ), ou seja: para os diferentes estratos, segundo os índices mais significativos de cada indicador.

$O$ estrato baixo inferior em sua maioria, situa-se nas faixas de rendimento de $1 / 2$ a 2 salários mínimos $(81,2 \%)$. O número de membros 
concentrou-se nas faixas de 4 a 6 pessoas $(56,2 \%)$. Na escolaridade ${ }^{5}$, os maiores índices ficaram nos níveis: primário $(37,5 \%)$ ao ginasial incompleto $(37,5 \%)$. Quanto a habitação, houve maior concentração para as seguintes condições: própria $(43,7 \%)$, cedida $(25,0 \%)$ ou alugada $(18,7 \%)$. Quanto as situações habitacionais obtivemos: insatisfatória $(31,2 \%)$ a regulares $(43,8 \%)$. No que se refere ao nível ocupacional, a maior concentração ocorreu na categoria de trabalhadores rurais $(31,3 \%)$ e trabalhadores assalariados urbanos $(18,7 \%)$.

O estrato baixo superior em sua maioria, situa-se nas faixas de rendimento de 2 a 4 salários mínimos $(64,7 \%)$ e de 4 a 9 salários mínimos $(23,5 \%)$. O número de membros concentrou-se nas faixas de até 4 pessoas $(41,2 \%)$ e de 4 a 6 pessoas (47,0\%). Na escolaridade, os maiores índices ficaram nos níveis: do ginasial incompleto $(23,5 \%)$ ao colegial completo (52,9\%). Quanto a habitação, houve maior concentração para as seguintes condições: cedida $(52,9 \%)$, alugada ou própria (23,5\% cada). Quanto as situações habitacionais obtivemos: regulares $(41,2 \%)$ e boa $(35,2 \%)$ No que se refere ao nível ocupacional, a maior concentração ocorreu nos trabalhadores assalariados $(64,7 \%)$ e trabalhadores autônomos (35,3\%).

O estrato médio inferior em sua maioria, situa-se nas faixas de rendimento de 9 a 15 salários mínimos $(75,0 \%)$ ou de 15 a 30 salários mínimos $(25,0 \%)$. O número de membros concentrou-se nas faixas de até 6 pessoas $(100,0 \%)$. Na escolaridade, os maiores índices ficaram nos níveis: colegial incompleto $(50,0 \%)$ e colegial completo $(50,0 \%)$. Quanto a habitação, houve maior concentração para as seguintes condições: própria $(75,0 \%)$ com situação habitacional regular ou insatisfatória $(25,0 \%)$ a boa $(50,0 \%)$. No que se refere ao nível ocupacional, a maior concentração ocorreu nos trabalhadores assalariados $(75,0 \%)$ e trabalhadores assalariados administrativos técnicos científicos $(25,0 \%)$.

5 Com relação a escolaridade, adotamos a terminologia do instrumental proposto (primário - de $1^{\mathrm{a}}$ a $4^{\mathrm{a}}$
série e ginásio - da $5^{\mathrm{a}}$ a $8^{\mathrm{a}}$ série), tendo, porém, consciência da nova denominação segundo a "Lei de
Diretrizes e Bases da Educação Nacional: educação básica (educação infantil, ensino fundamental e
médio) e educação superior. Fonte: Brasil. Presidência da República Casa Subchefia para Assuntos
Jurídicos Lei 9394 de 20 de dezembro de 1996 . Estabelece as diretrizes e bases da educação nacional.
[on line].
[consultado http://www.presidencia.gov.br/ccivil 03/Leis/L9394.htm. 
O estrato médio foi representado na totalidade na faixa de rendimento de 30 a 60 salários mínimos. O número de membros concentrou-se na faixa com até 4 pessoas; nível de escolaridade, colegial completo; habitação em condição casa própria e situação habitacional boa. No que se refere ao nível ocupacional, este ficou na categoria de trabalhador assalariado administrativo técnico científico.

Essa análise sugere não haver relação direta entre distúrbios de comunicação e estratificação social. A somatória dos estratos baixos totalizou respectivamente $85,0 \%$ (GI) e 88,8\% (GII). Indicando que, as condições socioeconômicas são relativamente melhores no GI - com distúrbios (BS 50,0\% e $\mathrm{BI} 35,0 \%$ ) do que no GII - sem distúrbios (BS 38,8\% e BI 50,0\%), pois houve maior índice do estrato baixo superior ao estrato baixo inferior. A análise estatística desta categoria - estratificação social - não apresentou associação estatisticamente significante com os grupos $(p=0,064)$.

\section{2 - Histórico e dinâmica familiar - Eixo 2.}

Este segundo eixo de análise teve a preocupação de buscar informações pertinentes a situação conjugal e religiosa da família, (estado civil, forma e tempo de união e religião).

Buscamos também dados referentes ao planejamento familiar, (número de filhos, métodos anticonceptivos e a influência do nascimento do paciente na decisão quanto ao número de filhos do casal e orientação genética).

Os pais participantes foram, também, questionados sobre a gestação, reações, sentimentos, significados, dificuldades e interferência do nascimento da criança com fissura labiopalatina no relacionamento familiar.

Os dados coletados com estas informações estão especificados nas tabelas: 3, 4 e 5 . 
Tabela 3 - Situação conjugal e religiosa da família

\begin{tabular}{|c|c|c|c|c|c|c|}
\hline \multirow{2}{*}{ Categorias } & \multicolumn{2}{|c|}{ G I } & \multicolumn{2}{|c|}{ G II } & \multicolumn{2}{|c|}{$\frac{\text { Total }}{(\mathrm{GI}+\mathrm{GII})}$} \\
\hline & $\bar{n}$ & $\%$ & $\mathbf{n}$ & $\%$ & $\mathbf{n}$ & $\%$ \\
\hline \multicolumn{7}{|l|}{ Estado civil: } \\
\hline Casado $\left(^{*}\right)$ & 12 & 60,0 & 10 & 55,6 & 22 & 57,9 \\
\hline União consensual & 2 & 10,0 & 2 & 11,1 & 4 & 10,5 \\
\hline Solteiro & 4 & 20,0 & 6 & 33,3 & 10 & 26,3 \\
\hline Separado & 2 & 10,0 & - & - & 2 & 5,3 \\
\hline TOTAL & 20 & 100,0 & 18 & 100,0 & 38 & 100,0 \\
\hline \multicolumn{7}{|l|}{ Forma de união $\left(^{*}\right)$ : } \\
\hline Civil & 12 & 100,0 & 9 & 90,0 & 21 & 95,4 \\
\hline Religioso & 10 & 83,3 & 6 & 60,0 & 16 & 72,7 \\
\hline TOTAL & 12 & - & 10 & - & 22 & - \\
\hline \multicolumn{7}{|l|}{ Vida em comum: } \\
\hline Sem vida em comum & 6 & 30,0 & 4 & 22,2 & 10 & 26,3 \\
\hline $\begin{array}{l}\text { Com vida em comum } \\
\left({ }^{* *}\right)\end{array}$ & 14 & 70,0 & 14 & 77,8 & 28 & 73,9 \\
\hline TOTAL & 20 & 100,0 & 18 & 100,0 & 38 & 100,0 \\
\hline \multicolumn{7}{|l|}{ Tempo de união $\left(^{* *}\right)$ : } \\
\hline 0 a 5 anos & 1 & 7,1 & 1 & 7,1 & 2 & 7,1 \\
\hline 6 a 10 anos & 3 & 21,4 & 6 & 42,9 & 9 & 32,1 \\
\hline 11a 15 anos & 2 & 14,3 & 3 & 21,4 & 5 & 17,9 \\
\hline Acima de 16 anos & 8 & 57,2 & 4 & 28,6 & 12 & 42,9 \\
\hline TOTAL & 14 & 100,0 & 14 & 100,0 & 28 & 100,0 \\
\hline \multicolumn{7}{|l|}{ Religião: } \\
\hline Católica & 14 & 70,0 & 15 & 83,3 & 29 & 76,3 \\
\hline Evangélica/ protestante & 4 & 20,0 & 1 & 5,6 & 5 & 13,2 \\
\hline Espírita & 1 & 5,0 & - & - & 1 & 2,6 \\
\hline Sem religião & 1 & 5,0 & - & - & 1 & 2,6 \\
\hline Outras & - & - & 2 & 11,1 & 2 & 5,3 \\
\hline TOTAL & 20 & 100,0 & 18 & 100,0 & 38 & 100,0 \\
\hline
\end{tabular}

A tabela 3 refere-se a situação conjugal e religiosa da família. Esta revela tanto na totalidade da amostra $(57,9 \%)$ como no GI $(60,0 \%)$ e GII (55,6\%), a predominância do estado civil - casado sobre os outros, que incluem solteiros, separados e união consensual. A opção pela forma de união na totalidade da amostra são de casamentos somente no civil $(95,4 \%)$, seguido do religioso $(72,7 \%)$ sendo que a religião predominante $(76,3 \%)$, foi a católica. 
Demonstra também que os casais, em sua maioria, tem estabilidade de vida em comum (73,9\%), diferenciando nos grupos quanto ao tempo de união: acima de 16 anos para o GI (57,2\%), e de 6 a 10 anos, para as famílias do GII $(42,9 \%)$.

Por outro lado, encontramos um índice significativo $(26,3 \%)$ na totalidade, e em ambos os grupos, de mães que geraram o filho sem ter tido vida em comum com o pai.

Correlacionando esses dados com o censo da população brasileira de 2000, também encontramos a maior incidência para os casados e/ou união consensual $(49,5 \%)$, seguido do solteiro $(38,6 \%)$, além dos outros estados civis (Instituto Brasileiro de Geografia e Estatística 2005).

Na revisão da literatura, foi destacado por José Filho (2002), a existência de vários arranjos familiares na atualidade e também identificados nesta pesquisa a exemplo de uniões livres e mulheres que decidem ter filhos sem companheiro estável.

Com relação a religião, o Instituto Brasileiro de Geografia e Estatística (2006), aponta a predominância de catolicismo no país $(73,7 \%)$, seguido dos evangélicos $(15,4 \%)$ índices esses bem próximos dos achados nesta pesquisa.

O Teste estatístico Qui-quadrado $\left(x^{2}\right)$ aplicado na tabela 3 nas categorias estado civil $(p=0,478)$, vida em comum $(p=0,590)$ e tempo de união $(p=0,469)$ não apresentaram significância estatística entre os grupos.

Ligado diretamente a situação conjugal e religiosa da família, está o planejamento familiar que será abordado na tabela 4.

\section{Tabela 4 - Planejamento familiar}

\begin{tabular}{|c|c|c|c|c|c|c|}
\hline \multirow[t]{2}{*}{ Categorias } & \multicolumn{2}{|c|}{ G I } & \multicolumn{2}{|c|}{ G II } & \multicolumn{2}{|c|}{$\begin{array}{c}\text { Total } \\
(\mathrm{GI}+\mathrm{GII}) \\
\end{array}$} \\
\hline & $\bar{n}$ & $\%$ & $n$ & $\%$ & $n$ & $\%$ \\
\hline $\begin{array}{l}\text { Ordem de } \\
\text { nascimento: }\end{array}$ & & & & & & \\
\hline $1^{\circ}$ & 9 & 45,0 & 8 & 44,4 & 17 & 44,7 \\
\hline $2^{\circ}$ & 6 & 30,0 & 7 & 38,9 & 13 & 34,2 \\
\hline $3^{\circ}$ & 4 & 20,0 & 2 & 11,1 & 6 & 15,8 \\
\hline $4^{\circ}$ & 1 & 5,0 & 1 & 5,6 & 2 & 5,3 \\
\hline TOTAL & 20 & 100,0 & 18 & 100,0 & 38 & 100,0 \\
\hline
\end{tabular}


Continuação

\begin{tabular}{|c|c|c|c|c|c|c|}
\hline \multicolumn{7}{|l|}{ Número de filhos: } \\
\hline 1 & 6 & 30,0 & 6 & 33,3 & 12 & 31,5 \\
\hline 2 & 5 & 25,0 & 5 & 27,8 & 10 & 26,3 \\
\hline 3 & 3 & 15,0 & 5 & 27,8 & 8 & 21,1 \\
\hline 4 & 6 & 30,0 & 2 & 11,1 & 8 & 21,1 \\
\hline TOTAL & 20 & 100,0 & 18 & 100,0 & 38 & 100,0 \\
\hline \multicolumn{7}{|l|}{ Pretensão/ter mais filhos: } \\
\hline Sim & 1 & 5,0 & 2 & 11,1 & 3 & 7,9 \\
\hline Não & 17 & 85,0 & 14 & 77,8 & 31 & 81,6 \\
\hline Não responderam & 2 & 10,0 & 2 & 11,1 & 4 & 10,5 \\
\hline TOTAL & 20 & 100,0 & 18 & 100,0 & 38 & 100,0 \\
\hline \multicolumn{7}{|l|}{$\begin{array}{l}\text { Utilização de método } \\
\text { anticonceptivo: }\end{array}$} \\
\hline Sim & 16 & 80,0 & 13 & 72,2 & 29 & 76,3 \\
\hline Não & 2 & 10,0 & 2 & 11,1 & 4 & 10,5 \\
\hline Não responderam & 1 & 5,0 & 2 & 11,1 & 3 & 7,9 \\
\hline Outros & 1 & 5,0 & 1 & 5,6 & 2 & 5,3 \\
\hline TOTAL & 20 & 100,0 & 18 & 100,0 & 38 & 100,0 \\
\hline \multicolumn{7}{|l|}{ Especificações: } \\
\hline Anticoncepcional (Pílula) & 7 & 43,8 & 5 & 38,4 & 12 & 41,4 \\
\hline Esterilização feminina & 5 & 31,2 & 4 & 30,8 & 9 & 31,0 \\
\hline Esterilização masculina & 2 & 12,5 & - & - & 2 & 6,9 \\
\hline Outros & 2 & 12,5 & 4 & 30,8 & 6 & 20,7 \\
\hline TOTAL & 16 & 100,0 & 13 & 100,0 & 29 & 100,0 \\
\hline \multicolumn{7}{|l|}{$\begin{array}{l}\text { Decisão /não ter mais } \\
\text { filhos após nascimento } \\
\text { paciente: }\end{array}$} \\
\hline Sim & 2 & 11,8 & 4 & 28,6 & 6 & 19,4 \\
\hline Não & 15 & 88,2 & 10 & 71,4 & 25 & 80,6 \\
\hline TOTAL & 17 & 100,0 & 14 & 100,0 & 31 & 100,0 \\
\hline \multicolumn{7}{|c|}{ Receio / Recorrência / FLP: } \\
\hline Sim & 6 & 30,0 & 8 & 44,4 & 14 & 36,8 \\
\hline Não & 12 & 60,0 & 8 & 44,4 & 20 & 52,7 \\
\hline Outros & 2 & 10,0 & 2 & 11,2 & 4 & 10,5 \\
\hline TOTAL & 20 & 100,0 & 18 & 100,0 & 38 & 100,0 \\
\hline \multicolumn{7}{|l|}{$\begin{array}{l}\text { Orientação/ setor de } \\
\text { genética: }\end{array}$} \\
\hline Sim & 9 & 45,0 & 13 & 72,2 & 22 & 57,9 \\
\hline Não & 5 & 25,0 & 1 & 5,6 & 6 & 15,8 \\
\hline Não lembra & 6 & 30,0 & 4 & 22,2 & 10 & 26,3 \\
\hline TOTAL & 20 & 100,0 & 18 & 100,0 & 38 & 100,0 \\
\hline
\end{tabular}

A tabela 4 refere-se ao planejamento familiar, sendo que primeiramente abordamos a ordem de nascimento do paciente, cujos dados na totalidade da amostra, concentrou-se no primogênito em $44,7 \%$, seguido de $34,2 \%$ como o segundo filho do casal. Estes índices se equilibram com os dois grupos individualmente.

Com relação ao número de filhos, observamos na totalidade da amostra, tanto a opção por filho único (31,5\%) como a opção por 2 a 4 filhos $(68,5 \%)$, confirmando dados da realidade brasileira em que o número médio de 
pessoas por família é de 3,4 (Instituto Brasileiro de Geografia e Estatística 2003).

Analisando os grupos individualmente com relação ao número de filhos, percebemos uma diferença, pois, no GI os casais têm, em sua maioria, 1 ou 4 filhos, e no Gll os casais optaram em ter no máximo até 3 filhos.

A presença da fissura labiopalatina no primogênito poderá influenciar na decisão de ter mais filhos.

Como é possível visualizar, a maioria dos casais da totalidade da amostra não pretendem ter mais filhos $(81,6 \%)$, destacando-se que $76,3 \%$ se utilizam de algum método anticonceptivo, sendo a pílula, o método anticoncepcional mais utilizado $(41,4 \%)$, seguido da esterilização feminina $(31,0 \%)$.

Segundo dados no censo de 2000, a utilização de algum método anticonceptivo entre mulheres é de $76,7 \%$, sendo a pílula utilizada em $20,7 \%$ dos casais e a esterilização feminina em 40,1\%.

Os achados nesta pesquisa, quanto ao método anticonceptivo utilizado confirmam os dados da realidade brasileira evidenciados na literatura.

Ressaltamos que a decisão de não ter mais filhos tanto na totalidade $(80,6 \%)$, como nos grupos, não ocorreu para a maioria em função do nascimento do paciente com fissura labiopalatina, e sim devido a fatores como: profissionais, financeiros, pessoais e outros.

Quanto ao receio de ter outro filho com fissura labiopalatina, constatamos tanto na totalidade da amostra $(52,7 \%)$ como nos grupos, isoladamente, um maior índice de não preocupação. Observamos porém no GII igual índice dos que se preocupam ou não com a recorrência (44,4\%). Em ambos os grupos, houve predominância das famílias que receberam orientações do setor de genética, sobre os que não receberam, ou não se lembram do atendimento. Na totalidade da amostra, o índice de orientação genética foi de $57,9 \%$, seguido dos que não se lembram $(26,3 \%)$.

A questão do aconselhamento genético precisa ser revista pela equipe, pois um percentual significativo de mães alegam não terem recebido, ou não se lembram das orientações do setor. Este fato parece estar relacionado diretamente ao estresse e à expectativa do primeiro atendimento, 
como "casos novos". Mesmo a área de genética tendo realizado esse tipo de abordagem, as mães estão normalmente preocupadas com a alimentação e os procedimentos cirúrgicos da criança. Ressaltamos porém a possibilidade de reagendamento para este setor quando solicitado pela família em qualquer fase do tratamento.

O teste estatístico de significância aplicado nas categorias número de filhos $(p=0,493)$, receio de ter outro filho com fissura $(p=0,612)$, e orientação do setor de genética $(p=0,157)$, não evidenciaram índice de significância entre os grupos.

Diante do já exposto sobre a composição familiar e sua estrutura, o que será abordado agora é a gestação e o nascimento, como um marco na vida dos pais.

Tabela 5 - Gestação e nascimento

\begin{tabular}{|c|c|c|c|c|c|c|c|}
\hline \multirow{2}{*}{\multicolumn{2}{|c|}{ Categorias }} & \multicolumn{2}{|c|}{ G I } & \multicolumn{2}{|c|}{ G II } & \multicolumn{2}{|c|}{$\frac{\text { Total }}{(\mathrm{GI}+\mathrm{GII})}$} \\
\hline & & $\mathbf{n}$ & $\%$ & $n$ & $\%$ & $\bar{n}$ & $\%$ \\
\hline \multicolumn{8}{|c|}{$\begin{array}{l}\text { Época do diagnóstico da } \\
\text { fissura: }\end{array}$} \\
\hline \multicolumn{2}{|c|}{ No nascimento } & 18 & 90,0 & 15 & 83,3 & 33 & 86,9 \\
\hline \multicolumn{2}{|c|}{ Outros } & - & - & 1 & 5,6 & 1 & 2,6 \\
\hline \multicolumn{2}{|c|}{ TOTAL } & 20 & 100,0 & 18 & 100,0 & 38 & 100,0 \\
\hline \multicolumn{8}{|c|}{ Informante/diagnóstico da FLP: } \\
\hline \multicolumn{2}{|c|}{ Médico } & 15 & 75,0 & 15 & 83,3 & 30 & 79,0 \\
\hline \multicolumn{2}{|c|}{ Enfermeira } & 4 & 20,0 & - & - & 4 & 10,5 \\
\hline \multicolumn{2}{|c|}{ Outros } & 1 & 5,0 & 2 & 11,1 & 3 & 7,9 \\
\hline \multicolumn{2}{|c|}{ Desconhece } & - & - & 1 & 5,6 & 1 & 2,6 \\
\hline \multicolumn{2}{|c|}{ TOTAL } & 20 & 100,0 & 18 & 100,0 & 38 & 100,0 \\
\hline \multicolumn{8}{|c|}{$\begin{array}{l}\text { Reação dos pais/ocorrência da } \\
\text { fissura: }\end{array}$} \\
\hline \multirow[t]{4}{*}{ Pai: } & Positiva & 8 & 40,0 & 5 & 27,8 & 13 & 34,2 \\
\hline & Negativa & 9 & 45,0 & 11 & 61,1 & 20 & 52,6 \\
\hline & Desconhece & 3 & 15,0 & 2 & 11,1 & 5 & 13,2 \\
\hline & TOTAL & 20 & 100,0 & 18 & 100,0 & 38 & 100,0 \\
\hline \multirow[t]{2}{*}{ Mãe: } & Positiva & 6 & 30,0 & 7 & 38,8 & 13 & 34,2 \\
\hline & Negativa & 14 & 70,0 & 10 & 55,6 & 24 & 63,2 \\
\hline
\end{tabular}


Continuação

\begin{tabular}{|c|c|c|c|c|c|c|}
\hline Desconhece & - & - & 1 & 5,6 & 1 & 2,6 \\
\hline TOTAL & 20 & 100,0 & 18 & 100,0 & 38 & 100,0 \\
\hline \multicolumn{7}{|l|}{ Sentimento de culpa: } \\
\hline Sim & 3 & 15,0 & 3 & 16,7 & 6 & 15,8 \\
\hline Não & 17 & 85,0 & 14 & 77,8 & 31 & 81,6 \\
\hline Desconhece & - & - & 1 & 5,5 & 1 & 2,6 \\
\hline TOTAL & 20 & 100,0 & 18 & 100,0 & 38 & 100,0 \\
\hline \multicolumn{7}{|c|}{ Dificuldades no nascimento: } \\
\hline Sim & 8 & 40,0 & 8 & 44,4 & 16 & 42,1 \\
\hline Não & 12 & 60,0 & 9 & 50,0 & 21 & 55,3 \\
\hline Não respondeu & - & - & 1 & 5,6 & 1 & 2,6 \\
\hline TOTAL & 20 & 100,0 & 18 & 100,0 & 38 & 100,0 \\
\hline \multicolumn{7}{|c|}{ Causas atribuídas pelos pais: } \\
\hline Genética & 5 & 25,0 & 9 & 50,0 & 14 & 36,8 \\
\hline Ambiental & 7 & 35,0 & 6 & 33,3 & 13 & 34,2 \\
\hline Cultural & 2 & 10,0 & 1 & 5,6 & 3 & 7,9 \\
\hline Desconhece & 6 & 30,0 & 2 & 11,1 & 8 & 21,1 \\
\hline TOTAL & 20 & 100,0 & 18 & 100,0 & 38 & 100,0 \\
\hline \multicolumn{7}{|c|}{ Denominação da anomalia: } \\
\hline Malformação & - & - & 4 & 22,2 & 4 & 10,5 \\
\hline Fissura & 6 & 30,0 & 2 & 11,1 & 8 & 21,1 \\
\hline Lábio leporino & 10 & 50,0 & 12 & 66,7 & 22 & 57,9 \\
\hline Outros & 4 & 20,0 & - & - & 4 & 10,5 \\
\hline TOTAL & 20 & 100,0 & 18 & 100,0 & 38 & 100,0 \\
\hline
\end{tabular}

A tabela 5 sobre gestação e nascimento demonstra a homogeneidade dos resultados na maioria das respostas do Grupo I, Grupo II, e GI+GII para as diferentes categorias.

Com relação a época e informante do diagnóstico da fissura labiopalatina pode-se destacar que os pais foram comunicados pelos médicos $(79,0 \%)$, na ocasião do nascimento $(86,9 \%)$, e uma minoria $(10,5 \%)$ tomou conhecimento no período pré-natal, por meio da ultrassonografia. Isto sugere que a maioria das pessoas não tem acesso a essa tecnologia ou não foi diagnosticado pelo médico.

Segundo Altmann (1997), os avanços ultrassonográficos permitem o diagnóstico precoce intra-útero e, quando isto ocorre, é possível tranqüilizar a família já nessa ocasião e, acima de tudo, prepará-la para a chegada do bebê, 
sem os traumas de uma notícia inesperada, pois estarão cientes dos tratamentos existentes, das possibilidades de reabilitação.

Jones (1984) relata que as fissuras labiais associadas ou não a fissuras palatais podem ser detectadas no pré-natal mediante a ultrassonografia, destacando porém sua preocupação com a possibilidade dos casais optarem pela não continuidade da gravidez; daí a importância da orientação da equipe sobre a malformação e o tratamento.

Observamos um maior índice para as reações negativas, tanto do pai $(52,6 \%)$ como da mãe $(63,2 \%)$, com a ocorrência da fissura labiopalatina. As reações negativas das mães quando comparadas aos pais, tanto na totalidade da amostra $(63,2 \%)$ como no GI (52,6\%) apresentou maior índice. Dentre as reações negativas destacamos: susto, desespero, depressão, choque e rejeição conforme depoimentos dos pesquisados.

Quando questionados sobre o sentimento de culpa do casal $(81,6 \%)$, observamos que a maioria, tanto na amostra geral $(81,6 \%)$ como nos dois grupos, não foi manifestado.

Com relação as dificuldades encontradas no nascimento $55,3 \%$ dos pais da totalidade revelaram não terem encontrado dificuldades assim como nos grupos isoladamente. Mas $42,1 \%$ dos pais encontraram dificuldades, relacionadas a alimentação, preocupação com o seguimento do tratamento e gastos decorrentes, falta de informações sobre os serviços de reabilitação e outras.

Essas mesmas preocupações encontradas na pesquisa foram também observadas na literatura por Amaral (1997) ao relatar que no início, os pais se preocupam em como lidar com o problema de sobrevivência da criança, alimentação e aparência. Mais tarde, a preocupação será a fala, a dentição e o desenvolvimento social.

Dentre as causas da ocorrência da fissura labiopalatina atribuídas pelos pais, no $\mathrm{Gl}$ ficou evidente as causas ambientais (35,0\%) ou desconhecidas $(30,0 \%)$, e no GIl as genéticas $(50,0 \%)$ e ambientais $(33,3 \%)$. $\mathrm{Na}$ totalidade, o maior índice ocorreu para genética $(36,8 \%)$, seguido das ambientais $(34,2 \%)$, como no GII. 
Embora o fator cultural (7,9\%) tenha tido uma pequena representatividade, há citações na literatura, entre elas Oliveira (1992), de que, dentre as causas atribuídas pelos pais com relação a ocorrência das fissuras, há referências aos fatores religiosos e às crendices populares. Em nossa pesquisa destacou-se nessa categoria, a religiosidade.

Se de um lado ainda é grande o número de pessoas que desconhecem as prováveis causas do nascimento de uma criança com fissura labiopalatina $(21,1 \%)$, outras ainda atribuem a crenças e superstições $(7,9 \%)$.

Com relação a denominação da anomalia, os pais referem-se a mesma como "lábio-leporino" (50,0\%), seguido de "fissura" $(30,0 \%)$ no GI, e na totalidade $57,9 \%$ e $21,9 \%$ respectivamente.

No GII a denominação "lábio-leporino" (66,7\%) foi seguida de “malformação" (22,2\%).

$\mathrm{Na}$ análise estatística da tabela 5, foram aplicados o Teste Qui-quadrado $\left(x^{2}\right)$ nas categorias: diagnóstico da fissura $(p=0,557)$; reação dos pais/ocorrência da fissura $(p=0,610)$; sentimento de culpa $(p=0,552)$, não havendo significância estatística nos grupos I e II nessas categorias.

Diversas foram as causas atribuídas pelos pais ao nascimento da criança com fissura assim como suas reações. O que será abordado a seguir são as repercussões do nascimento na família.

Tabela 6 - Repercussões do nascimento na família: relacionamento e significado

\begin{tabular}{|c|c|c|c|c|c|c|}
\hline \multirow{2}{*}{ Categorias } & \multicolumn{2}{|c|}{ G I } & \multicolumn{2}{|c|}{ G II } & \multicolumn{2}{|c|}{$\frac{\text { Total }}{\text { ( GI + GII ) }}$} \\
\hline & $n$ & $\%$ & $n$ & $\%$ & $n$ & $\%$ \\
\hline $\begin{array}{l}\text { Relacionamento conju } \\
\text { do nascimento: } \\
\text { União }\end{array}$ & 17 & 85,0 & 15 & 83,5 & 32 & 84,2 \\
\hline Conflito & 3 & 15,0 & 1 & 5,5 & 4 & 10,6 \\
\hline Outros & - & - & 1 & 5,5 & 1 & 2,6 \\
\hline Desconhece & - & - & 1 & 5,5 & 1 & 2,6 \\
\hline TOTAL & 20 & 100,0 & 18 & 100,0 & 38 & 100,0 \\
\hline
\end{tabular}


Continuação

\begin{tabular}{lrrrrrr}
\hline Na época nascimento: & 16 & 80,0 & 13 & 72,2 & 29 & 76,3 \\
União & 2 & 10,0 & 3 & 16,6 & 5 & 13,2 \\
Conflito & - & - & 1 & 5,6 & 1 & 2,6 \\
Outros & 2 & 10,0 & 1 & 5,6 & 3 & 7,9 \\
Desconhece & $\mathbf{2 0}$ & $\mathbf{1 0 0 , 0}$ & $\mathbf{1 8}$ & $\mathbf{1 0 0 , 0}$ & $\mathbf{3 8}$ & $\mathbf{1 0 0 , 0}$ \\
TOTAL & & & & & & \\
\hline Relacionamento atual: & 17 & 85,0 & 15 & 83,3 & 32 & 84,2 \\
União & 1 & 5,0 & - & - & 1 & 2,6 \\
Conflito & - & - & 2 & 11,1 & 2 & 5,3 \\
Outros & 2 & 10,0 & 1 & 5,6 & 3 & 7,9 \\
Desconhece & $\mathbf{2 0}$ & $\mathbf{1 0 0 , 0}$ & $\mathbf{1 8}$ & $\mathbf{1 0 0 , 0}$ & $\mathbf{3 8}$ & $\mathbf{1 0 0 , 0}$ \\
TOTAL & & & & & & \\
\hline Significado / filho com fissura: & 17 & 85,0 & 15 & 83,3 & 32 & 84,2 \\
Positivo & 3 & 15,0 & 2 & 11,1 & 5 & 13,2 \\
Negativo & - & - & 1 & 5,6 & 1 & 2,6 \\
Não respondeu & $\mathbf{2 0}$ & $\mathbf{1 0 0 , 0}$ & $\mathbf{1 8}$ & $\mathbf{1 0 0 , 0}$ & $\mathbf{3 8}$ & $\mathbf{1 0 0 , 0}$ \\
TOTAL & & & & & &
\end{tabular}

$\mathrm{Na}$ tabela 6 observou-se em todos os grupos, repercussões no relacionamento do casal na época do nascimento do filho com fissura labiopalatina, quando comparados aos relacionamentos anterior e atual.

Analisando essas repercussões, observamos que embora os casais se mantivessem unidos nas 3 fases assinaladas, houve uma oscilação na época do nascimento $(76,3 \%)$, em comparação a fase anterior $(84,2 \%)$ e a atual $(84,2 \%)$.

Com relação ao aumento do índice de situações conflituosas na época do nascimento $(13,2 \%)$ quando comparadas a fase anterior $(10,6 \%)$ e a posterior $(2,6 \%)$, observamos por um lado, o aumento das dificuldades enfrentadas durante o nascimento, mas por outro, a sua superação com a retomada da união dos casais em maior índice. A literatura destaca que o nascimento da criança com fissura labiopalatina desencadeia situações traumáticas como choque, impacto, frustrações, causando estresse no sistema familiar. A sua superação dependerá de como a família irá lidar com essas situações podendo recuperá-la a curto, médio, longo prazo ou nunca (Freitas 1974, Chinelatto 1994, Neves e Paixão 1994, Amaral 1997 e Yamada 1998). 
$\mathrm{Na}$ totalidade da amostra, a maioria dos pais $(84,2 \%)$ declarou ser positivo o significado em ter um filho portador de fissura labiopalatina, e uma minoria $(13,2 \%)$ revelou um sentimento negativo frente a este problema, resultados estes similares nos grupos isoladamente.

Nos depoimentos sobre o significado positivo, destacamos: o despertar para uma realidade desconhecida e seu enfrentamento; crescimento, amadurecimento pessoal e familiar; religiosidade e possibilidade de tratamento no Hospital, como elementos facilitadores da aceitação. Na situação inversa significado negativo - foram destacados os sentimentos de tristeza e preocupação com relação as implicações tanto funcionais como estéticas e psicossociais nas diferentes fases do desenvolvimento, infância à idade adulta.

Rego (1990) ressalta que os pais lidarão com o problema de acordo com seus próprios recursos internos e externos. Os recursos internos eliciados vão depender da personalidade da mãe, de seus valores e crenças, experiências prévias de vida, maturidade, capacidade de lidar com problemas, habilidades sociais, apoio social e recursos materiais. A extensão e a gravidade do problema, também tem sua influência: quanto mais grave, maiores as dificuldades. Quanto aos recursos externos, dependerão da família, amigos e profissionais que vão ajudar a enfrentar a situação e acolher os pais, conhecendo e compreendendo sua história, seu contexto de vida, seus anseios, dificuldades e expectativas.

O importante é que os pais compreendam que os sentimentos por eles experenciados, diante da ocorrência da fissura labiopalatina são comuns e, devem ser manifestos sem julgamentos, discriminação ou interpretações.

Para análise estatística desta tabela 6, foram aplicados o Teste Quiquadrado $\left(\mathrm{x}^{2}\right)$ nas categorias: relacionamento conjugal antes do nascimento $(p=0,387)$; na época do nascimento $(p=0,515)$; relacionamento atual $(p=0,339)$ e significado em ter um filho com fissura $(p=0,543)$, não havendo significância estatística nos grupos I e II nessas categorias. 


\section{3 - Relações sociais do indivíduo e família - Eixo 3.}

O enfoque dado a este terceiro eixo de análise foi direcionado para o conhecimento das repercussões da fissura labiopalatina nas relações sociais do indivíduo e da família.

Neste eixo, apresentamos dados quanto a situação profissional e social da família antes e após o nascimento da criança com fissura labiopalatina, reações dos pais mediante a observação do filho com fissura em público, preocupação do casal em manter diálogo com o paciente preparando-o para o tratamento e enfrentamento social, bem como as relações sociais do paciente, a influência da fissura labiopalatina nos relacionamentos familiares e na vida escolar.

Tabela 7 - Relações sociais da família

\begin{tabular}{|c|c|c|c|c|c|c|c|}
\hline \multirow{2}{*}{\multicolumn{2}{|c|}{ Categorias }} & \multicolumn{2}{|c|}{ G I } & \multicolumn{2}{|c|}{ G II } & \multicolumn{2}{|c|}{$\frac{\text { Total }}{(\mathrm{GI}+\mathrm{GII})}$} \\
\hline & & $n$ & $\%$ & $n$ & $\%$ & $n$ & $\%$ \\
\hline \multicolumn{8}{|c|}{$\begin{array}{l}\text { Inserção profissional da } \\
\text { mãe: }\end{array}$} \\
\hline Sim & & 8 & 40,0 & 14 & 77,8 & 22 & 57,9 \\
\hline Não & & 12 & 60,0 & 4 & 22,2 & 16 & 42,1 \\
\hline TOTAL & & 20 & 100,0 & 18 & 100,0 & 38 & 100,0 \\
\hline \multicolumn{8}{|l|}{ Regime: } \\
\hline Integral & & 5 & 62,5 & 8 & 57,1 & 13 & 59,0 \\
\hline Parcial & & 3 & 37,5 & 6 & 42,9 & 9 & 41,0 \\
\hline TOTAL & & 8 & 100,0 & 14 & 100,0 & 22 & 100,0 \\
\hline \multicolumn{8}{|c|}{$\begin{array}{l}\text { Alteração da vida } \\
\text { profissional da mãe após o } \\
\text { nascimento: }\end{array}$} \\
\hline $\operatorname{Sim}$ & & 5 & 25,0 & 6 & 33,3 & 11 & 28,9 \\
\hline Não & & 15 & 75,0 & 12 & 66,7 & 27 & 71,1 \\
\hline TOTAL & & 20 & 100,0 & 18 & 100,0 & 38 & 100,0 \\
\hline \multicolumn{8}{|l|}{ Atividade de lazer: } \\
\hline \multirow[t]{2}{*}{ Antes do nascimento: } & Sim & 17 & 85,0 & 17 & 94,4 & 34 & 89,5 \\
\hline & Não & 3 & 15,0 & 1 & 5,6 & 4 & 10,5 \\
\hline TOTAL & & 20 & 100,0 & 18 & 100,0 & 38 & 100,0 \\
\hline
\end{tabular}




\begin{tabular}{|c|c|c|c|c|c|c|}
\hline Continuação & & & & & & \\
\hline Depois do nascimento: $\quad$ Sim & 18 & 90,0 & 14 & 77,8 & 32 & 84,2 \\
\hline Não & 2 & 10,0 & 4 & 22,2 & 6 & 15,8 \\
\hline TOTAL & 20 & 100,0 & 18 & 100,0 & 38 & 100,0 \\
\hline Alteração das atividades: Sim & 3 & 15,0 & 7 & 38,9 & 10 & 26,3 \\
\hline Não & 17 & 85,0 & 11 & 61,1 & 28 & 73,7 \\
\hline TOTAL & 20 & 100,0 & 18 & 100,0 & 38 & 100,0 \\
\hline $\begin{array}{l}\text { Reação pais - pacientes } \\
\text { observados em público: } \\
\text { Naturalmente }\end{array}$ & 17 & 85,0 & 15 & 83,3 & 32 & 84,2 \\
\hline Negativamente & 2 & 10,0 & 2 & 11,5 & 4 & 10,5 \\
\hline Nunca percebeu & 1 & 5,0 & 1 & 5,6 & 2 & 5,3 \\
\hline TOTAL & 20 & 100,0 & 18 & 100,0 & 38 & 100,0 \\
\hline $\begin{array}{l}\text { Diálogo paciente/ } \\
\text { tratamento: } \\
\text { Sim }\end{array}$ & 20 & 100,0 & 18 & 100,0 & 38 & 100,0 \\
\hline TOTAL & 20 & 100,0 & 18 & 100,0 & 38 & 100,0 \\
\hline $\begin{array}{l}\text { Preparo/enfrentamento } \\
\text { social: } \\
\text { Sim }\end{array}$ & 18 & 90,0 & 14 & 77,8 & 32 & 84,2 \\
\hline Não & 2 & 10,0 & 4 & 22,2 & 6 & 15,8 \\
\hline TOTAL & 20 & 100,0 & 18 & 100,0 & 38 & 100,0 \\
\hline
\end{tabular}

$\mathrm{Na}$ tabela 7, que focaliza as relações sociais da família, podemos visualizar que quanto a inserção profissional da mãe fora do lar, a totalidade da amostra revela que o número das que não trabalham $(42,1 \%)$, é menor ao das que trabalham $(57,9 \%)$, e estas o fazem em sua maioria em regime integral $(59,0 \%)$, situações essas também observadas nos grupos individualmente.

Comparando os grupos observamos que a maioria das mães do GI não trabalha $(60,0 \%)$, diferentemente do GII, que apresenta um índice expressivo $(77,8 \%)$ de mães que exercem atividades profissionais fora do lar.

Correlacionando esses dados com a literatura, observamos que a inserção da mulher no mercado de trabalho tem aumentado nos últimos anos. Segundo o Instituto Brasileiro de Geografia e Estatística (2006), o índice de mulheres ocupadas no mercado de trabalho aumentou de 2001 para 2004, respectivamente de $40,7 \%$ para $41,8 \%$, em comparação com os homens que diminuiu de $59,3 \%$ para $58,2 \%$. 
Em 2001, 82,8\% das mulheres de 25 a 49 anos (mães) tinham pelo menos um filho. Essa informação é importante porque as mulheres que têm a responsabilidade de cuidar dos filhos sentem mais dificuldade de ingressar e permanecer no mercado de trabalho (Instituto Brasileiro de Geografia e Estatística 2003).

Essa dificuldade pode aumentar quando trata-se de filho com deficiência, pois os dados desta pesquisa apontaram alteração na vida profissional da mãe após o nascimento (28,9\%), seja uma interrupção temporária ou definitiva das atividades por opção ou necessidade da dedicação exclusiva ao filho.

Quanto as atividades de lazer antes e após o nascimento da criança com fissura labiopalatina, os dados demonstraram em sua maioria, tanto nos grupos GI e GII, como na totalidade $(73,7 \%)$ a não alteração nestas atividades, sendo que a reação dos pais frente a observação do paciente em público $(84,2 \%)$, foi de naturalidade. Entre os que reagiram negativamente $(10,5 \%)$, alguns relatam que vão conversar com a pessoa que observava o filho e outros entristecem e se afastam do local para chorar.

Entre os que alteraram as atividades de lazer (26,3\%), a maioria não foi em decorrência da fissura, mas a outros fatores: o lazer passou a não ser prioridade para a família, situação financeira, número de filhos, trabalho e outros. Somente algumas mães relataram que os cuidados com a saúde da criança principalmente com relação ao ouvido passaram a ser mais intensos, evitando, portanto, passeios como praia e piscina.

A literatura revela situações em que os pais escondem a criança com fissura labiopalatina restringindo-se contatos sociais, especialmente antes da cirurgia (Freitas, 1974). Por outro lado, encontramos relatos segundo Pertschuck e Whitaker (1985), que os pais tratam os filhos com deformidade como normais, não hesitando em levá-los a qualquer ambiente, embora muitos pais relatassem raiva ao verem seus filhos observados em público.

Em ambos os grupos GI, Gll e na totalidade, os pais foram unânimes em referir o diálogo com o paciente sobre o tratamento realizado no HRAC $(100,0 \%)$. Sobre o preparo dos filhos para o enfrentamento social, 
constatamos na totalidade a predominância $(84,2 \%)$ quando comparados aos que não preparam $(15,8 \%)$.

Comparando os grupos, houve maior índice de preparo para 0 enfrentamento social no GI (90,0\%) quando comparados ao GII $(77,8 \%)$.

Portanto, o diálogo visa prepará-los para o tratamento, enfrentamento social e vida futura, havendo minoria em ambos os grupos que sentem dificuldades de lidar com estas questões.

Os pais, segundo Amaral (1997), ocupam papel muito importante na vida da criança, constituindo-se na fonte reforçadora mais valorizada pela criança, e, conseqüentemente, tendo um papel relevante na sua formação.

Os Testes estatísticos Qui-quadrado $\left(x^{2}\right)$ aplicados na tabela 7 demonstraram não haver diferença significante entre os grupos nas categorias período de trabalho $(p=0,806)$, alteração profissional de mãe após nascimento $(p=0,344)$; atividade de lazer depois do nascimento $(p=0,302)$; alteração das atividades de lazer $(p=0,095)$ e reações dos pais quando os filhos são observados em público $(p=0,990)$.

$\mathrm{Na}$ categoria inserção profissional da mãe $(p=0,019)$, o resultado do teste estatístico demonstrou haver associação estatisticamente significante nos grupos GI (com distúrbios) e Gll (sem distúrbios), sugerindo esta análise não haver correlação entre a não inserção profissional da mãe no mercado de trabalho e desenvolvimento da fala.

Completando o eixo 3, após tratarmos sobre as relações sociais da família, focalizaremos o paciente neste contexto.

\section{Tabela 8 - Relações sociais do paciente na família}

\begin{tabular}{|c|c|c|c|c|c|c|}
\hline \multirow[t]{2}{*}{ Categorias } & \multicolumn{2}{|c|}{ G I } & \multicolumn{2}{|c|}{ G II } & \multicolumn{2}{|c|}{$\frac{\text { Total }}{(\mathrm{GI}+\mathrm{GII})}$} \\
\hline & $\mathbf{n}$ & $\%$ & $\mathbf{n}$ & $\%$ & $\mathbf{n}$ & $\%$ \\
\hline $\begin{array}{l}\text { Maior convi } \\
\text { com: } \\
\text { Pais }\end{array}$ & - & - & 1 & 5,6 & 1 & 2,6 \\
\hline Mãe & 13 & 65,0 & 8 & 44,4 & 21 & 55,3 \\
\hline Pai & 1 & 5,0 & 1 & 5,6 & 2 & 5,3 \\
\hline
\end{tabular}




\begin{tabular}{|c|c|c|c|c|c|c|c|}
\hline \multicolumn{8}{|l|}{ Continuação } \\
\hline \multicolumn{2}{|l|}{ Avós } & 1 & 5,0 & 6 & 33,3 & 7 & 18,4 \\
\hline \multicolumn{2}{|l|}{ Irmãos } & 2 & 10,0 & - & - & 2 & 5,3 \\
\hline \multicolumn{2}{|l|}{ Tios } & 1 & 5,0 & - & - & 1 & 2,6 \\
\hline \multicolumn{2}{|l|}{ Empregada } & 1 & 5,0 & - & - & 1 & 2,6 \\
\hline \multicolumn{2}{|l|}{ Outros } & 1 & 5,0 & 2 & 11,1 & 3 & 7,9 \\
\hline \multicolumn{2}{|l|}{ TOTAL } & 20 & 100,0 & 18 & 100,0 & 38 & 100,0 \\
\hline \multicolumn{8}{|c|}{ Relacionamento do Paciente: } \\
\hline \multirow[t]{4}{*}{ Pai: } & Bom & 17 & 85,0 & 16 & 88,9 & 33 & 86,9 \\
\hline & Ruim & 1 & 5,0 & - & - & 1 & 2,6 \\
\hline & Outros & 2 & 10,0 & 2 & 11,1 & 4 & 10,5 \\
\hline & TOTAL & 20 & 100,0 & 18 & 100,0 & 38 & 100,0 \\
\hline \multirow[t]{3}{*}{ Mãe: } & Bom & 19 & 95,0 & 18 & 100,0 & 37 & 97,2 \\
\hline & Regular & 1 & 5,0 & - & - & 1 & 2,6 \\
\hline & TOTAL & 20 & 100,0 & 18 & 100,0 & 38 & 100,0 \\
\hline \multirow[t]{3}{*}{ Irmão: } & Bom & 14 & 93,3 & 11 & 91,7 & 25 & 92,6 \\
\hline & Regular & 1 & 6,7 & 1 & 8,3 & 2 & 7,4 \\
\hline & TOTAL & 15 & 100,0 & 12 & 100,0 & 27 & 100,0 \\
\hline \multirow[t]{4}{*}{ Amigos família: } & Bom & 18 & 90,0 & 18 & 100,0 & 36 & 94,8 \\
\hline & Regular & 1 & 5,0 & - & - & 1 & 2,6 \\
\hline & Ruim & 1 & 5,0 & - & - & 1 & 2,6 \\
\hline & TOTAL & 20 & 100,0 & 18 & 100,0 & 38 & 100,0 \\
\hline
\end{tabular}

Na tabela 8, a figura materna na convivência com o paciente atingiu os maiores índices tanto na totalidade da amostra (55,3\%), como no GI $(65,0 \%)$ e GII $(44,4 \%)$.

Observou-se que o alto índice de convivência do paciente com a mãe no $\mathrm{Gl}(65,0 \%)$ pode estar relacionado ao fato de $60 \%$ delas, não estarem exercendo atividades profissionais fora do lar, como demonstrado na tabela 7.

A convivência com os avós foi citada em ambos os grupos, atingindo seu maior índice $(33,3 \%)$ no GII.

Excluindo-se as categorias empregadas (2,6\%) e outros $(7,9 \%)$ constatamos que em $89,5 \%$ dos casos, a convivência do paciente dá-se no contexto familiar nas categorias de: pai, mãe, avós, tios e irmãos, o que sugere um conhecimento qualitativo desse relacionamento. 
O relacionamento do paciente com os membros da família, na totalidade da amostra, foi avaliado como bom, em todas as categorias: pai $(86,9 \%)$, mãe $(97,2 \%)$, irmão $(92,6 \%)$ e amigos da família $(94,8 \%)$.

Estes altos índices também foram observados para todas as categorias, e nos grupos individualmente.

Confirma-se assim, com base na literatura (Kaloustian 1994 e José Filho 2002), que a família tem uma imensa significação na vida das pessoas, e é dentro desse quadro de convivência com conflitos e alegrias que se percebe a importância de se ter um ambiente familiar que proporcione aos indivíduos uma vida plena e feliz. É a família que propicia os aportes afetivos e sobretudo, materiais necessários ao desenvolvimento e bem estar de seus componentes e é o primeiro ponto de referencial social.

Para análise estatística da tabela 8, foram aplicados Teste Qui-quadrado $\left(x^{2}\right)$ nas categorias maior convivência do paciente $(p=0,188)$, relacionamento do paciente com o pai $(p=0,629)$ e com os amigos/família $(p=0,387)$. O Teste Exato de Fisher foi aplicado no relacionamento com a mãe $(p=0,526)$ e irmão $(p=0,565)$.

$\mathrm{Na}$ tabela 8, não houve associação estatisticamente significante entre os grupos.

O primeiro meio social onde o ser humano se insere é a família; a entrada na escola amplia o seu meio e influi diretamente no seu desenvolvimento.

Considerando que a grande maioria dos pacientes está em idade escolar, abordaremos, a seguir, a questão da inserção do paciente na escola e suas relações sociais.

Tabela 9 - Relações sociais do paciente na escola

\begin{tabular}{|c|c|c|c|c|c|c|c|}
\hline \multirow{2}{*}{\multicolumn{2}{|c|}{ Categorias }} & \multicolumn{2}{|c|}{ G I } & \multicolumn{2}{|c|}{ G II } & \multicolumn{2}{|c|}{$\frac{\text { Total }}{\text { ( GI + GII ) }}$} \\
\hline & & $\bar{n}$ & $\%$ & $\mathbf{n}$ & $\%$ & 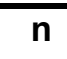 & $\%$ \\
\hline \multirow[t]{3}{*}{ Situação escolar: } & Não estuda & 1 & $\overline{5,0}$ & 1 & $\overline{5,6}$ & 2 & 5,3 \\
\hline & Estuda $\left({ }^{*}\right)$ & 19 & 95,0 & 17 & 94,4 & 36 & 94,7 \\
\hline & TOTAL & 20 & 100,0 & 18 & 100,0 & 38 & 100,0 \\
\hline
\end{tabular}


Continuação

\begin{tabular}{|c|c|c|c|c|c|c|}
\hline \multicolumn{7}{|c|}{ Modalidade de ensino $\left(^{*}\right)$ : } \\
\hline Básico/Creche & - & - & 1 & 5,9 & 1 & 2,8 \\
\hline Básico/Pré-escola & 2 & 10,5 & 4 & 23,5 & 6 & 16,7 \\
\hline Fundamental & 17 & 89,5 & 12 & 70,6 & 29 & 80,5 \\
\hline TOTAL & 19 & 100,0 & 17 & 100,0 & 36 & 100,0 \\
\hline \multicolumn{7}{|c|}{ Idade inicial escolar: } \\
\hline 0 a 4 anos & 12 & 63,2 & 9 & 52,9 & 21 & 58,3 \\
\hline 5 a 6 anos & 5 & 26,3 & 8 & 47,1 & 13 & 36,1 \\
\hline 7 anos acima & 2 & 10,5 & - & - & 2 & 5,6 \\
\hline TOTAL & 19 & 100,0 & 17 & 100,0 & 36 & 100,0 \\
\hline \multicolumn{7}{|c|}{$\begin{array}{l}\text { Adaptação e relacionamento } \\
\text { escolar: }\end{array}$} \\
\hline Regular & 2 & 10,5 & 3 & 17,6 & 5 & 13,9 \\
\hline Ruim & 5 & 26,3 & - & - & 5 & 13,9 \\
\hline TOTAL & 19 & 100,0 & 17 & 100,0 & 36 & 100,0 \\
\hline \multicolumn{7}{|c|}{$\begin{array}{l}\text { Participação dos pais na vida } \\
\text { escolar: }\end{array}$} \\
\hline TOTAL & 19 & 100,0 & 17 & 100,0 & 36 & 100,0 \\
\hline
\end{tabular}

Na tabela 9 - Relações sociais do paciente na escola - é possível visualizar que na totalidade da amostra (94,7\%) com relação a situação escolar, a maioria dos indivíduos estudam, e quanto a modalidade, cursam o ensino fundamental (80,5\%). Para os grupos GI e GIl esse alto índice também foi observado.

A idade inicial escolar predominante foi de 0 a 4 anos tanto na totalidade da amostra (58,3\%) como nos grupos isoladamente, seguida de 5 a 6 anos (36,1\%). Especialmente com relação ao Gl, verificamos maior concentração na faixa de 0 a 4 anos, portanto mais precocemente que o GII.

O fato de ingressar mais cedo na escola e ter maiores oportunidades de socialização não está diretamente relacionado a presença ou não de distúrbios da fala, embora não tenha havido significância estatística entre os grupos $(p=0,221)$.

A adaptação e relacionamento escolar obteve maiores índices como bom tanto na amostra total $(72,2 \%)$ como no GI e GII. Porém, no GI houve um 
índice significativo de ruim $(26,3 \%)$, ao contrario do Gll, em que não foi observado nenhum caso.

Embora esses dados não tenham apresentado evidência estatística ( $p=0,072$ ), observamos que o GI (com distúrbios) comparado ao GIl (sem distúrbios) apresentou menor índice de adaptação.

Estes dados vão ao encontro dos achados na literatura, dentre os quais, Amaral (1997), ao relatar que a criança com desfiguramento facial apresenta muitas vezes, problemas fonoaudiológicos associados, e estas características podem influenciar a percepção dos profissionais, que, por sua vez, pode afetar o desenvolvimento da criança em sala de aula.

A participação dos pais na vida escolar foi unânime nos diferentes grupos, reforçando a idéia de que a escola, responsável pelo desenvolvimento, aprendizagem, e socialização da criança, deve ser alvo de orientações e acompanhamento por parte dos pais, e da equipe reabilitadora.

Os Testes Qui-quadrado $\left(x^{2}\right)$ aplicado nas categorias modalidade $(p=0,297)$; idade inicial escolar $(p=0,221)$ e adaptação e relacionamento escolar $(p=0,072)$ demonstram que não houve associação estatisticamente significante entre os grupos.

$\mathrm{Na}$ fase escolar, o convívio social também é marcado por curiosidade, preconceito, discriminação, e suas conseqüências, podendo afetar o relacionamento social dos indivíduos, como será verificado a seguir.

Tabela 10 - Relações sociais do paciente

\begin{tabular}{|c|c|c|c|c|c|c|}
\hline \multirow[t]{2}{*}{ Categorias } & \multicolumn{2}{|c|}{ G I } & \multicolumn{2}{|c|}{ G II } & \multicolumn{2}{|c|}{$\frac{\text { Total }}{(\mathrm{GI}+\mathrm{GII})}$} \\
\hline & $\mathrm{n}$ & $\%$ & $\mathbf{n}$ & $\%$ & $\mathrm{n}$ & $\%$ \\
\hline \multicolumn{7}{|c|}{ Apelido relacionado à fissura: } \\
\hline Sim & 4 & 20,0 & 4 & 22,2 & 8 & 21,1 \\
\hline Não & 16 & 80,0 & 14 & 77,8 & 30 & 78,9 \\
\hline TOTAL & 20 & 100,0 & 18 & 100,0 & 38 & 100,0 \\
\hline \multicolumn{7}{|c|}{ Dificuldade de novas relações: } \\
\hline Sim & 3 & 15,0 & 1 & 5,6 & 4 & 10,5 \\
\hline Não & 17 & 85,0 & 17 & 94,4 & 34 & 89,5 \\
\hline TOTAL & 20 & 100,0 & 18 & 100,0 & 38 & 100,0 \\
\hline
\end{tabular}


Continuação

\begin{tabular}{|c|c|c|c|c|c|c|c|}
\hline \multicolumn{2}{|c|}{$\begin{array}{l}\text { Dificuldade de comunicação/ } \\
\text { relacionamento social: } \\
\text { Sim }\end{array}$} & 5 & 25,0 & - & - & 5 & 13,2 \\
\hline \multicolumn{2}{|l|}{ Não } & 15 & 75,0 & 18 & 100,0 & 33 & 86,8 \\
\hline \multicolumn{2}{|l|}{ TOTAL } & 20 & 100,0 & 18 & 100,0 & 38 & 100,0 \\
\hline \multicolumn{8}{|c|}{ Especificação das áreas: } \\
\hline \multirow[t]{3}{*}{ Escola: } & Sim & 5 & 25,0 & 1 & 5,6 & 6 & 15,8 \\
\hline & Não & 15 & 75,0 & 15 & 94,4 & 30 & 84,2 \\
\hline & TOTAL & 20 & 100,0 & 18 & 100,0 & 38 & 100,0 \\
\hline \multirow[t]{3}{*}{ Social: } & Sim & 3 & 15,0 & - & - & 3 & 7,9 \\
\hline & Não & 17 & 85,0 & 18 & 100,0 & 35 & 92,1 \\
\hline & TOTAL & 20 & 100,0 & 18 & 100,0 & 38 & 100,0 \\
\hline \multirow[t]{2}{*}{ Família: } & Não & 20 & 100,0 & 18 & 100,0 & 38 & 100,0 \\
\hline & TOTAL & 20 & 100,0 & 18 & 100,0 & 38 & 100,0 \\
\hline \multicolumn{2}{|c|}{$\begin{array}{l}\text { Avaliação geral das relações } \\
\text { sociais dos pacientes pelos pais: } \\
\text { Bom }\end{array}$} & 16 & 80,0 & 18 & 100,0 & 34 & 89,5 \\
\hline \multicolumn{2}{|l|}{ Regular } & 4 & 20,0 & - & - & 4 & 10,5 \\
\hline \multicolumn{2}{|l|}{ TOTAL } & 20 & 100,0 & 18 & 100,0 & 38 & 100,0 \\
\hline
\end{tabular}

A tabela 10 revela que, tanto na totalidade da amostra como nos grupos isolados, houve um índice significativo de crianças vítimas de chacotas no ambiente escolar com destaque para apelidos preconceituosos. Na totalidade este índice atingiu $21,1 \%$ e nos grupos individuais $20,0 \%$ para o GI e $22,2 \%$ para o GII.

Os apelidos mais comuns foram "boca torta", "nariz torto", "furadinho", "rasgadinho".

Tal situação é referida na literatura, especialmente por Jones (1984) ao destacar que além dos apelidos, as crianças com malformações são olhadas com curiosidade e têm dificuldades de novos contatos sociais.

Como pode ser constatado na pesquisa, o índice de dificuldade de novas relações atingiu mais aos indivíduos dos GI $(15,0 \%)$ do que do GII (5,6\%), ficando a totalidade da amostra com o índice de 10,5\%.

A dificuldade de comunicação e/ou relacionamento social foi destacado também por uma minoria na totalidade da amostra $(13,2 \%)$ e no GI 
(25,0\%), grupo este com distúrbio, ao contrário do Gll em que tal situação não foi constatada.

Correlacionando a ocorrência dessas dificuldades, encontramos na esfera escolar o maior índice para o GI (25,0\%) quando comparado ao GII $(5,6 \%)$ e à totalidade da amostra (15,8\%).

Altmann et al (1997), relata que a fissura traz para o indivíduo uma série de contingências físicas, psicológicas, afetivas e sociais e que produzem conseqüências, manifestadas em algumas características comumente encontradas no grupo como: redução no auto conceito, maior dependência dos pais, isolamento, esquiva de contatos sociais em situações novas, entre outras.

Dentre as dificuldades no ambiente escolar foram relatados pelos pais: isolamento da criança, discriminação, agressões físicas e verbais, dentre outras.

$\mathrm{Na}$ esfera social, o índice foi menor em comparação a escola, e o Gl foi o único que apresentou dificuldades de comunicação/relacionamento social com o índice de $15,0 \%$.

No ambiente familiar, não foram relatadas dificuldades em nenhum grupo, remetendo-nos as situações encontradas na tabela 8, sobre 0 relacionamento do paciente na família.

Estes baixos índices de dificuldades nas diversas esferas sociais revelam os resultados positivos do processo de reabilitação do qual participaram pais, professores, profissionais compromissados com todas as fases do desenvolvimento da criança a fim de que possam, conjuntamente, e com apoio da própria comunidade, aliançar os resultados almejados.

A avaliação geral das relações sociais dos pacientes pelos pais apresentou um resultado positivo (89,05\%).

No GII, $100,0 \%$ avaliaram as relações sociais como boas e no GI, o índice foi de $80,0 \%$, confirmando a importância da postura participativa dos pais, ponto principal do tratamento e da vida da criança como um todo.

O Teste Qui-quadrado $\left(x^{2}\right)$ foi aplicado nas categorias apelido $(p=0,867)$; dificuldades de novas relações $(p=0,344)$ e avaliação geral das relações sociais dos pacientes pelos pais $(p=0,107)$ não evidenciaram significância estatística entre os grupos. 
O Teste Exato de Fisher foi aplicado nas categorias dificuldades de comunicação/relacionamento social $(p=0,048)$; escola $(p=0,184)$; social $(p=0,232)$.

Nestas categorias, a associação estatisticamente significante foi na categoria dificuldade de comunicação.

\section{4 - Tratamento reabilitador, recursos organizacionais e comunitários - Eixo 4.}

Este quarto eixo de análise teve como enfoque informações pertinentes sobre o conhecimento dos pais em relação às fissuras labiopalatinas, busca por outros recursos anteriormente à matrícula no HRAC, expectativas, satisfação e concepção da família sobre o tratamento.

Buscou-se também informações a respeito do tratamento fonoaudiológico realizado na cidade de origem, recursos, disponibilidades da família para acompanhamento às terapias e realização dos exercícios, periodicidade recomendada e realizada e modalidade dos atendimentos.

Enfocamos ainda o conhecimento da família sobre os recursos comunitários na cidade de origem, e os recursos utilizados para atender aos retornos ao HRAC.

Por meio das tabulações dos dados obtidos, elaboramos as tabelas 11, 12, 13, e 14.

Tabela 11 - Tratamento reabilitador

\begin{tabular}{|c|c|c|c|c|c|c|}
\hline \multirow{2}{*}{ Categorias } & \multicolumn{2}{|c|}{ G I } & \multicolumn{2}{|c|}{ G II } & \multicolumn{2}{|c|}{$\frac{\text { Total }}{(\mathrm{GI}+\mathrm{GII})}$} \\
\hline & $\bar{n}$ & $\%$ & $\mathbf{n}$ & $\%$ & $\bar{n}$ & $\%$ \\
\hline \multicolumn{7}{|l|}{ Conhecimento HRAC: } \\
\hline Antes do nascimento & 1 & 5,0 & 1 & 5,6 & 2 & 5,3 \\
\hline Após o nascimento & 19 & 95,0 & 17 & 94,4 & 36 & 94,7 \\
\hline TOTAL & 20 & 100,0 & 18 & 100,0 & 38 & 100,0 \\
\hline \multicolumn{7}{|c|}{ Informante sobre o HRAC: } \\
\hline Médico & 7 & 35,0 & 8 & 44,4 & 15 & 39,5 \\
\hline Enfermeira & 3 & 15,0 & - & - & 3 & 7,9 \\
\hline
\end{tabular}




\begin{tabular}{|c|c|c|c|c|c|c|}
\hline \multicolumn{7}{|l|}{ Continuação } \\
\hline Coordenador & 3 & 15,0 & - & - & 3 & 7,9 \\
\hline Pac/ família & 2 & 10,0 & - & - & 2 & 5,2 \\
\hline Outros & 5 & 25,0 & 10 & 55,6 & 15 & 39,5 \\
\hline TOTAL & 20 & 100,0 & 18 & 100,0 & 38 & 100,0 \\
\hline $\begin{array}{l}\text { Conhecimento dos } \\
\text { sobre fissura: } \\
\text { Sim }\end{array}$ & 6 & 30.0 & 8 & 44.4 & 14 & 36.8 \\
\hline Não & 14 & 70,0 & 10 & 55,6 & 24 & 63,2 \\
\hline TOTAL & 20 & 100,0 & 18 & 100,0 & 38 & 100,0 \\
\hline $\begin{array}{l}\text { Procura por outros } \\
\text { recursos anteriore } \\
\text { HRAC: }\end{array}$ & & & & & & \\
\hline Sim & 1 & 5,0 & 3 & 16,7 & 4 & 10,5 \\
\hline Não & 19 & 95,0 & 15 & 83,3 & 34 & 89,5 \\
\hline TOTAL & 20 & 100,0 & 18 & 100,0 & 38 & 100,0 \\
\hline $\begin{array}{l}\text { Concepção sobre } \\
\text { tratamento: }\end{array}$ & & & & & & \\
\hline Direito & 12 & 60,0 & 13 & 72,2 & 25 & 65,8 \\
\hline Favor & 7 & 35,0 & 3 & 16,6 & 10 & 26,3 \\
\hline Direito e favor & 1 & 5,0 & 1 & 5,6 & 2 & 5,3 \\
\hline Não sabe & - & - & 1 & 5,3 & 1 & 2,6 \\
\hline TOTAL & 20 & 100,0 & 18 & 100,0 & 38 & 100,0 \\
\hline $\begin{array}{l}\text { Expectativa da } \\
\text { família/áreas: } \\
\text { Estética/ cirúrgica }\end{array}$ & 7 & 35,0 & 8 & 44,4 & 15 & 39,4 \\
\hline Odontologia & 10 & 50,0 & 6 & 33,3 & 16 & 42,1 \\
\hline Fonoaudiologia & 10 & 50,0 & 7 & 38,8 & 17 & 44,7 \\
\hline Psicologia & 5 & 25,0 & 5 & 27,7 & 10 & 26,3 \\
\hline Social & 5 & 25,0 & 4 & 22,2 & 9 & 23,6 \\
\hline Reabilitação global & 2 & 10,0 & 7 & 38,8 & 7 & 23,6 \\
\hline Outros & 2 & 10,0 & - & - & 2 & 5,2 \\
\hline TOTAL & 20 & & 18 & & 38 & \\
\hline
\end{tabular}

A tabela 11 sobre o tratamento reabilitador - no que se refere ao conhecimento do HRAC evidencia que a maioria dos pacientes, seja na totalidade da amostra $(94,7 \%)$ como nos grupos individualmente - GI $(95,0 \%)$ e GII (94,4\%), tomou conhecimento sobre o HRAC somente após o nascimento da criança com fissura labiopalatina.

A informação sobre o HRAC foi prestada pelos médicos com um índice de $39,5 \%$ na totalidade da amostra, assim como os leigos e profissionais de outras áreas que alcançaram o mesmo índice. 
O destaque ficou para a categoria outros - leigos e outros profissionais que no Gll alcançou um índice de 55,6\%.

Entre estes, encontramos dentistas, fonoaudiólogos, assistentes sociais, pais de outros pacientes do HRAC, associações - de pais e pessoas com fissuras - na comunidade de origem e amigos.

No que se refere ao conhecimento dos pais sobre a fissura, o que se constatou foi que na totalidade da amostra a maioria $(63,2 \%)$ a desconhecia, com destaque para o GI (70,0\%) quando comparado com o GII (55,6\%).

Os pais com conhecimento sobre fissura, anteriormente ao nascimento da criança tinham parentes próximos e conhecidos da família com a malformação. Entre estes, o maior índice foi alcançado pelos pais do GII $(44,4 \%)$.

Ao tomarem conhecimento da fissura, a maioria dos pais procurou primeiramente o HRAC $(89,5 \%$ na totalidade da amostra) para tratamento. Entretanto, mesmo sabendo do HRAC, alguns pais (10,5\%) procuraram outros recursos anteriormente a vinda ao HRAC.

O HRAC é mantido prioritariamente pelo SUS e o tratamento é prestado como um direito garantido pela Constituição Federal Brasil (1988), no entanto, mesmo sendo esclarecidos sobre o direito à saúde, alguns pais $(26,3 \%$ na totalidade da amostra) ainda o consideram como um favor, diferentemente da maioria $(65,8 \%$ na totalidade da amostra) que tem a concepção do tratamento como direito da cidadania.

Analisando os grupos individualmente, observamos que no $\mathrm{Gl}$ os que concebem o tratamento como um favor somaram $35,0 \%$, índice elevado em relação ao GII $(16,6 \%)$ nessa categoria.

Independente da concepção sobre o tratamento, a expectativa da família após alguns anos de tratamento (de 4 a 9 anos, já operados no HRAC) foi múltipla em diversos níveis.

Se considerarmos a totalidade da amostra, a maior expectativa da família é reabilitação da fala (44,7\%) e estética/cirurgia (39,4\%).

Há de se considerar os índices alcançados pela expectativa em nível psicológico $(26,3 \%)$, social e a reabilitação global ambos com $23,6 \%$. 
Como os grupos se diferem com relação aos distúrbios da fala ( $\mathrm{Gl}$ com distúrbios e Gll sem distúrbios), a diferença nas expectativas da família, também foi evidenciada nas áreas de comando do tratamento reabilitador: cirurgia plástica que no GI teve um índice 35,0\% e no GII, 44,4\%, odontologia, no $\mathrm{GI}$, com $50,0 \%$ e no GII, 33,3\% e fonoaudiologia que no GI aliançou $50,0 \%$ e no GII, $38,8 \%$.

Nos demais níveis, a reabilitação global apresentou-se como expectativa de maior índice, no GII (38,8\%), enquanto no GI alcançou (10,0\%).

Mesmo sem significância estatística $(p=0,391)$, os dados sobre a expectativa das famílias revelam a maior preocupação do GI (com distúrbios) com a reabilitação fonoaudiológica e odontológica, áreas diretamente ligadas à fala, que segundo Suguimoto (2002), pode apresentar distúrbios em função das alterações dento-oclusais.

A reabilitação diz respeito ao desenvolvimento das pessoas com deficiência, nos aspectos funcionais, físicos, psíquicos, educacionais, sociais, profissionais e ocupacionais (Brasil, 1993a), portanto, engloba um conjunto de ações de atenção à saúde, visando tanto a promoção, prevenção e assistência às pessoas.

Portanto, a reabilitação pressupõe o trabalho de uma equipe interdisciplinar, com a interação das diversas áreas, numa visão de totalidade.

O Teste Qui-quadrado $\left(x^{2}\right)$ aplicado nas categorias concepção do tratamento $(p=0,468)$ e expectativa da família $(p=0,391)$ não demonstrou significância estatística entre os grupos.

A complexidade dos distúrbios de comunicação nas pessoas com fissura labiopalatina exige a atuação do fonoaudiólogo, com o objetivo de diagnosticar, orientar e planejar os procedimentos terapêuticos por meio de um programa integrado à equipe interdisciplinar (Nelli et al 1990).

Dos 38 pacientes da amostra, 32 tiveram indicação de tratamento fonoaudiológico, o GI (com distúrbios) na sua totalidade $(20=100,0 \%)$ e do GII (sem distúrbios), 12 (66,7\%).

As especificações da situação de tratamento fonoaudiológico dos pacientes são apresentados na tabela 12. 


\begin{tabular}{|c|c|c|c|c|c|c|}
\hline \multirow{2}{*}{ Categorias } & \multicolumn{2}{|c|}{ G I } & \multicolumn{2}{|c|}{ G II } & \multicolumn{2}{|c|}{$\frac{\text { Total }}{(\text { GI + GII ) }}$} \\
\hline & $\mathbf{n}$ & $\%$ & $\mathbf{n}$ & $\%$ & $n$ & $\%$ \\
\hline $\begin{array}{l}\text { Situação do tratamento/casos } \\
\text { com indicação: } \\
\text { Em fonoterapia }\end{array}$ & 9 & 45,0 & 2 & 16,7 & 11 & 34,4 \\
\hline Alta da fonoterapia & 3 & 15,0 & 8 & 66,6 & 11 & 34,4 \\
\hline Interrupção da fonoterapia & 8 & 40,0 & 2 & 16,7 & 10 & 31,2 \\
\hline TOTAL & 20 & 100,0 & 12 & 100,0 & 32 & 100,0 \\
\hline $\begin{array}{l}\text { Motivos da Interrupção da } \\
\text { fonoterapia: } \\
\text { Insatisfação com o atendimento }\end{array}$ & 2 & 25,0 & - & - & 2 & 25,0 \\
\hline $\begin{array}{l}\text { Dificuldades com transporte ou } \\
\text { acompanhante }\end{array}$ & 2 & 25,0 & - & - & 2 & 25,0 \\
\hline $\begin{array}{l}\text { Ausência/desativação de } \\
\text { recursos }\end{array}$ & 2 & 25,0 & 2 & 100,0 & 4 & 50,0 \\
\hline $\begin{array}{l}\text { Dificuldades de acesso } \\
\text { (demanda) }\end{array}$ & 2 & 25,0 & - & - & 2 & 25,0 \\
\hline TOTAL & 8 & 100,0 & 2 & 100,0 & 10 & 100,0 \\
\hline $\begin{array}{l}\text { Periodicidade recomendada } \\
\text { (casos em terapia): } \\
\text { Semanal }\end{array}$ & 1 & 11,1 & 1 & 50,0 & 2 & 18,2 \\
\hline 2 a 3 / semana & 8 & 88,9 & 1 & 50,0 & 9 & 81,8 \\
\hline TOTAL & 9 & 100,0 & 2 & 100,0 & 11 & 100,0 \\
\hline $\begin{array}{l}\text { Periodicidade realizada } \\
\text { (casos em terapia): } \\
\text { Semanal }\end{array}$ & 7 & 77,8 & 2 & 100,0 & 9 & 81,8 \\
\hline 2 a 3 / semana & 2 & 22,2 & - & - & 2 & 18,2 \\
\hline TOTAL & 9 & 100,0 & 2 & 100,0 & 11 & 100,0 \\
\hline $\begin{array}{l}\text { Modalidade do atendimento } \\
\text { (casos em terapia): } \\
\text { Público }\end{array}$ & 6 & 66,7 & 2 & 100,0 & 8 & 72,7 \\
\hline Convênio & 2 & 22,2 & - & - & 2 & 18,2 \\
\hline Outros & 1 & 11,1 & - & - & 1 & 9,1 \\
\hline TOTAL & 9 & 100,0 & 2 & 100,0 & 11 & 100,0 \\
\hline $\begin{array}{l}\text { Recursos de transporte/ tratam } \\
\text { fono: } \\
\text { Não utiliza }\end{array}$ & 1 & 11,1 & - & - & 1 & 9,1 \\
\hline Públicos & 1 & 11,1 & 1 & 50,0 & 2 & 18,2 \\
\hline Particular & 7 & 77,8 & 1 & 50,0 & 8 & 72,7 \\
\hline TOTAL & 9 & 100,0 & 2 & 100,0 & 11 & 100,0 \\
\hline Acompanhamento/terapias: & & & & & & \\
\hline Pai & 2 & 22,2 & - & - & 2 & 18,2 \\
\hline Mãe & 6 & 66,7 & - & - & 6 & 54,5 \\
\hline
\end{tabular}


Continuação

\begin{tabular}{lrrrrrr} 
Outros (tia e avó) & 1 & 11,1 & 2 & 100,0 & 3 & 27,3 \\
TOTAL & $\mathbf{9}$ & $\mathbf{1 0 0 , 0}$ & $\mathbf{2}$ & $\mathbf{1 0 0 , 0}$ & $\mathbf{1 1}$ & $\mathbf{1 0 0 , 0}$ \\
\hline $\begin{array}{l}\text { Disponibilidade para realizar } \\
\text { os exercícios: }\end{array}$ & & & & & & \\
Pai & 1 & 11,1 & - & - & 1 & 9,1 \\
Mãe & 6 & 66,7 & 1 & 50,0 & 7 & 63,6 \\
Outros (tia, avó, irmão) & 2 & 22,2 & 1 & 50,0 & 3 & 27,3 \\
TOTAL & $\mathbf{9}$ & $\mathbf{1 0 0 , 0}$ & $\mathbf{2}$ & $\mathbf{1 0 0 , 0}$ & $\mathbf{1 1}$ & $\mathbf{1 0 0 , 0}$ \\
\hline
\end{tabular}

Especificando a situação de tratamento dos casos com indicação de terapia fonoaudiológica, na totalidade da amostra (para ambos os grupos, $\mathrm{N}=38$ ), o índice de pacientes em terapia e de alta foi o mesmo $(34,4 \%)$, e os que interromperam o tratamento foi $31,2 \%$.

Analisando os grupos individualmente, observamos no GI (com distúrbios) que o maior índice $(45,0 \%)$ está entre os pacientes em terapia se comparado aos pacientes do GII (16,7\%).

O que se destaca, primeiramente, é o elevado índice de alta $(66,6 \%)$ do GII, comparado com o GI (15,0\%) que, além dessas situações, conta com um índice de $(40,0 \%)$ de pacientes que interromperam o tratamento próximo ao índice dos pacientes em terapia (45,0\%).

Dentre os motivos da interrupção estão:

- Insatisfação com o atendimento (público);

- Dificuldade financeira para transporte e/ou de disponibilidade de acompanhante;

- Ausência e/ou desativação de recursos;

- Dificuldades de acesso em virtude da demanda reprimida.

Pode-se dizer que todos os motivos da interrupção da terapia têm relação direta com a situação econômica das famílias, que, na sua maioria $(86,9 \%)$ pertence aos estratos baixos, conforme tabela 2. Evidenciam ainda a precariedade das políticas públicas na saúde, que embora previstas como direito na Constituição Federal de 1988 (Brasil 1988), certamente dependerá da mobilização tanto dos diretamente afetados, como de entidades representativas, a exemplo das Associações de Pais e Pessoas com Fissura Labiopalatina do país. 
Remetendo-nos aos pacientes que se encontram em terapia, algumas particularidades foram abordadas.

A periodicidade recomendada para terapia fonoaudiológica, na totalidade da amostra, foi de 2 a 3 vezes por semana para 81,8\% dos pacientes, dentre os quais apenas $18,2 \%$ atenderam a essa recomendação. Os demais $(81,8 \%)$ além de haverem reduzido a periodicidade das terapias para semanal, ainda têm que se submeter a restrição de tempo de terapia (30 minutos) em função da demanda do serviço público, da qual a maioria $(72,7 \%)$ depende, seguido de 18,2\% que utilizou de convênio de saúde.

No entanto o transporte para a terapia fonoaudiológica (paciente e acompanhante), fica sob a responsabilidade da família - recursos próprios em $72,7 \%$, na totalidade da amostra.

A participação da família na reabilitação é imprescindível, podendo resultar em recursos significativos de tratamento (Paynter et al 1991, Pannbacker e Scheuerle1993 e Altmann et al 1997). No caso de terapia fonoaudiológica o envolvimento dos membros da família se torna indispensável por exigir não só o acompanhamento às terapias, mas também disponibilidade para realizar os exercícios no domicílio.

A figura materna mais uma vez tem se destacado, pois o acompanhante mais freqüente das crianças na terapia é a mãe (54,5\% na totalidade da amostra e $66,7 \%$ no $\mathrm{Gl}$ ), assim como a disponibilidade em realizar os exercícios fonoaudiológicos no domicílio $(63,6 \%$ na totalidade da amostra, 66,7\% no GI e GII, 50,0\%).

Em função da duração do tratamento e suas exigências, a participação e/ou colaboração de outros membros da família têm sido requisitadas, como irmãos, tios e avós.

A análise estatística da categoria - situação de tratamento / casos com indicação - demonstrou haver associação estatisticamente significante entre os grupos $(p=0,012)$.

Além da participação da família no tratamento, a existência, o conhecimento e o acesso aos recursos, tanto no município de origem, como 
para fins de tratamento no HRAC, são fundamentais na viabilização do processo de reabilitação, tais como:

- Tratamento Fora do Domicílio (TFD): é um recurso que pode ser solicitado pelos usuários do Sistema Único de Saúde quando estiverem esgotados todos os meios de tratamento no local de origem (cidade onde o paciente reside), desde que haja possibilidade de recuperação total e parcial para a patologia apresentada. Esse benefício abrange pagamento de passagens e diárias ao paciente e acompanhante, pelo tempo de permanência no local de destino, no caso do HRAC/USP, em Bauru (Brasil 1999). Tem como objetivo assegurar aos usuários o acesso a atendimento não disponíveis nos seus municípios de origem.

- Pais coordenadores: são considerados agentes multiplicadores do HRAC nas diferentes regiões do país. Esses agentes são pais e/ou pacientes adultos que representam o Hospital e os portadores de deficiências de suas respectivas cidades, defendendo interesses comuns, especialmente os relacionados à reabilitação. Têm como funções básicas: o apoio, a divulgação, a mobilização e a organização das pessoas com fissuras labiopalatinas, passando a manter contatos com vários segmentos da sociedade.

- Carona Amiga: consiste no agrupamento de pacientes, por municípios, para fins de locomoção de sua cidade de origem até o HRAC, conforme necessidade de tratamento, propiciando assim, a racionalização do uso de transporte, um melhor entrosamento dos pacientes e familiares, bem como oportunidades iguais de reabilitação, estimulando inclusive a organização popular.

- Associações de pais e portadores de fissuras labiopalatinas: é uma realidade em muitas cidades, têm como finalidade prestar serviços de assistência e/ou reabilitação nos municípios de origem.

- Núcleos regionais: considerados como centros de atendimento ambulatoriais de apoio ao processo de reabilitação do HRAC, normalmente envolvem as áreas de medicina, odontologia, fonoaudiologia, psicologia e serviço social, incluindo as fases pré e pós cirúrgicas, dando o suporte para o seguimento do tratamento. 
- Sub-sedes: são unidades de atendimento ambulatorial mantidas pela Fundação para Estudo e Tratamento das Deformidades Crânio-Faciais (FUNCRAF) parceira do HRAC; já foram implantados três serviços de assistência ambulatorial no Brasil, ou seja, Campo Grande/MS, Itararé/SP e São Bernardo/SP.

As especificações dos recursos comunitários utilizados pelos pacientes para fins de tratamento serão apresentados na tabela 13.

Tabela 13 - Recursos comunitários para tratamento

\begin{tabular}{|c|c|c|c|c|c|c|}
\hline \multirow{2}{*}{ Categorias } & \multicolumn{2}{|c|}{ G I } & \multicolumn{2}{|c|}{ G II } & \multicolumn{2}{|c|}{$\begin{array}{c}\text { Total } \\
\text { ( GI + GII ) }\end{array}$} \\
\hline & $\mathbf{n}$ & $\%$ & $\mathrm{n}$ & $\%$ & $n$ & $\%$ \\
\hline \multicolumn{7}{|l|}{ Municípios/recursos: } \\
\hline Com* & 17 & 89,5 & 14 & 82,3 & 31 & 86,6 \\
\hline Sem & 2 & 10,5 & 3 & 17,7 & 5 & 13,4 \\
\hline TOTAL & 19 & 100,0 & 17 & 100, & 36 & 100,0 \\
\hline \multicolumn{7}{|c|}{$\begin{array}{l}\text { Conhecimento de recursos/ } \\
\text { pacientes: }\end{array}$} \\
\hline Não & 2 & 10,0 & 2 & 11,1 & 4 & 10,5 \\
\hline TOTAL & 20 & 100,0 & 18 & 100,0 & 38 & 100,0 \\
\hline \multicolumn{7}{|c|}{ Recursos disponíveis*: } \\
\hline TFD & 14 & 82,4 & 8 & 57,1 & 22 & 71,0 \\
\hline Coordenadores & 11 & 64,7 & 10 & 71,4 & 21 & 67,7 \\
\hline Carona Amiga & 8 & 47,0 & 9 & 64,3 & 17 & 54,8 \\
\hline $\begin{array}{l}\text { Continuação } \\
\text { Associações }\end{array}$ & 8 & 47,0 & 3 & 21,4 & 11 & 35,5 \\
\hline Núcleos & - & - & 1 & 7,1 & 1 & 3,2 \\
\hline Sub-sedes & 1 & 5,9 & - & - & 1 & 3,2 \\
\hline TOTAL & 17 & 100,0 & 14 & 100,0 & 31 & 100,0 \\
\hline \multicolumn{7}{|c|}{$\begin{array}{l}\text { Recursos conhecidos dos } \\
\text { disponíveis: }\end{array}$} \\
\hline TFD & 12 & 87,5 & 7 & 87,5 & 19 & 86,4 \\
\hline Coordenadores & 4 & 36,3 & 1 & 10,5 & 5 & 23,8 \\
\hline Carona Amiga & 7 & 87,5 & 9 & 100,0 & 16 & 94,1 \\
\hline Associações & 4 & 50,0 & 1 & 33,3 & 5 & 45,4 \\
\hline Núcleos & - & - & - & - & - & - \\
\hline Sub-sedes & 1 & 100,0 & - & - & 1 & 100,0 \\
\hline TOTAL & 18 & & 16 & & 31 & \\
\hline
\end{tabular}


Continuação

\begin{tabular}{lrrrrrr}
\hline $\begin{array}{l}\text { Recursos utilizados/vinda } \\
\text { HRAC: }\end{array}$ & 12 & 60,0 & 7 & 38,8 & 19 & 50,0 \\
TFD & 5 & 25,0 & 9 & 50,0 & 14 & 36,9 \\
Carona Amiga & 2 & 10,0 & 2 & 11,2 & 4 & 10,5 \\
Recursos próprios & 1 & 5,0 & - & - & 1 & 2,6 \\
Outros & $\mathbf{2 0}$ & $\mathbf{1 0 0 , 0}$ & $\mathbf{1 8}$ & $\mathbf{1 0 0 , 0}$ & $\mathbf{3 8}$ & $\mathbf{1 0 0 , 0}$ \\
TOTAL & & &
\end{tabular}

Para análise dos dados da tabela 13, verificamos os municípios da amostra que contam com recursos facilitadores de tratamento, tanto no município de origem, como para fins de tratamento no HRAC.

Observamos que os 38 pacientes da totalidade da amostra, procedem de 36 municípios, dos quais $31(86,6 \%)$ apresentam recursos facilitadores do tratamento, para somente $5(13,4 \%)$ sem nenhum recurso.

Dentre os pacientes da totalidade da amostra, observamos que $89,5 \%$ conhecem os recursos para o tratamento.

Correlacionando os diferentes tipos de recursos disponíveis e seu conhecimento por parte dos indivíduos, constatamos que o Tratamento Fora do Domicílio - TFD, na totalidade da amostra é viabilizado em $71,0 \%$ dos municípios e conhecido por $86,4 \%$ dos pacientes.

Os coordenadores estão presentes em $67,7 \%$ dos municípios, sendo conhecidos por $23,8 \%$ dos indivíduos, o que sugere maior divulgação do trabalho realizado por esses agentes multiplicadores. O que ocorre é que, nas cidades que possuem a "Carona Amiga" organizada, as atribuições dos coordenadores com relação ao transporte, passa a ser de responsabilidade das Prefeituras Municipais, diminuindo, portanto o índice de procura aos agentes.

Como reflexo dessa situação, a "Carona Amiga" disponível em 54,8\% dos municípios é conhecida por $94,1 \%$ dos pacientes, evidenciando a grande abrangência deste programa que se apresenta como viabilizador do tratamento.

As associações de pais e pessoas com fissuras labiopalatinas estão disponíveis em $35,5 \%$ dos municípios, sendo conhecidos por $45,4 \%$ dos pacientes.

Recentemente foi criada a "Rede Nacional de Pais e Portadores de Fissuras Labiopalatinas - REDE PROFIS", que tem como desafio incentivar a 
criação de novas associações no país. Sua finalidade é de congregar, integrar, representar e defender os interesses institucionais de suas associadas, colaborando com o desenvolvimento da solidariedade social (Bauru, 2006).

Os núcleos regionais de atendimento e as sub-sedes, na totalidade da amostra, estão presentes em apenas um município ( $3,2 \%$ para cada categoria), sendo que somente a sub-sede é do conhecimento de um indivíduo da amostra, residente nesse município (100\%).

Tanto as associações, como os núcleos e sub-sedes, têm um compromisso com as pessoas portadoras de deficiência dos seus respectivos municípios, em apoio à política de descentralização dos serviços, defendida e implementada pelo HRAC.

Com relação aos recursos utilizados para o comparecimento ao HRAC/USP, na totalidade da amostra, o maior índice ficou para o Tratamento Fora do Domicílio (50,0\%), seguido da Carona Amiga (36,9\%) e recursos próprios $(10,5 \%)$ dentre outros (2,6\%). Evidencia-se mais uma vez que $86,9 \%$ utilizam recursos públicos de transporte para acesso ao tratamento em Bauru.

Estes altos índices obtidos na totalidade da amostra se mantêm nos grupos individualmente.

Este aparato extra-muros é resultado de uma prática criativa e propositiva desenvolvida pela equipe do Serviço Social do hospital, conjugando seus esforços com o paciente / família e representantes comunitários na defesa dos direitos de cidadania.

A análise estatística, Teste Exato de Fisher, na categoria município/recursos $(p=0,650)$, e conhecimento de recursos/pacientes $(p=1,000)$ e recursos utilizados para vinda $(p=0,339)$ não apresentaram associação estatisticamente significante entre os grupos.

Já identificados os recursos de apoio e quais os mais utilizados, o último questionamento foi sobre a satisfação do paciente que é de fundamental importância como medida de qualidade da assistência prestada, assunto a ser analisado a seguir. 


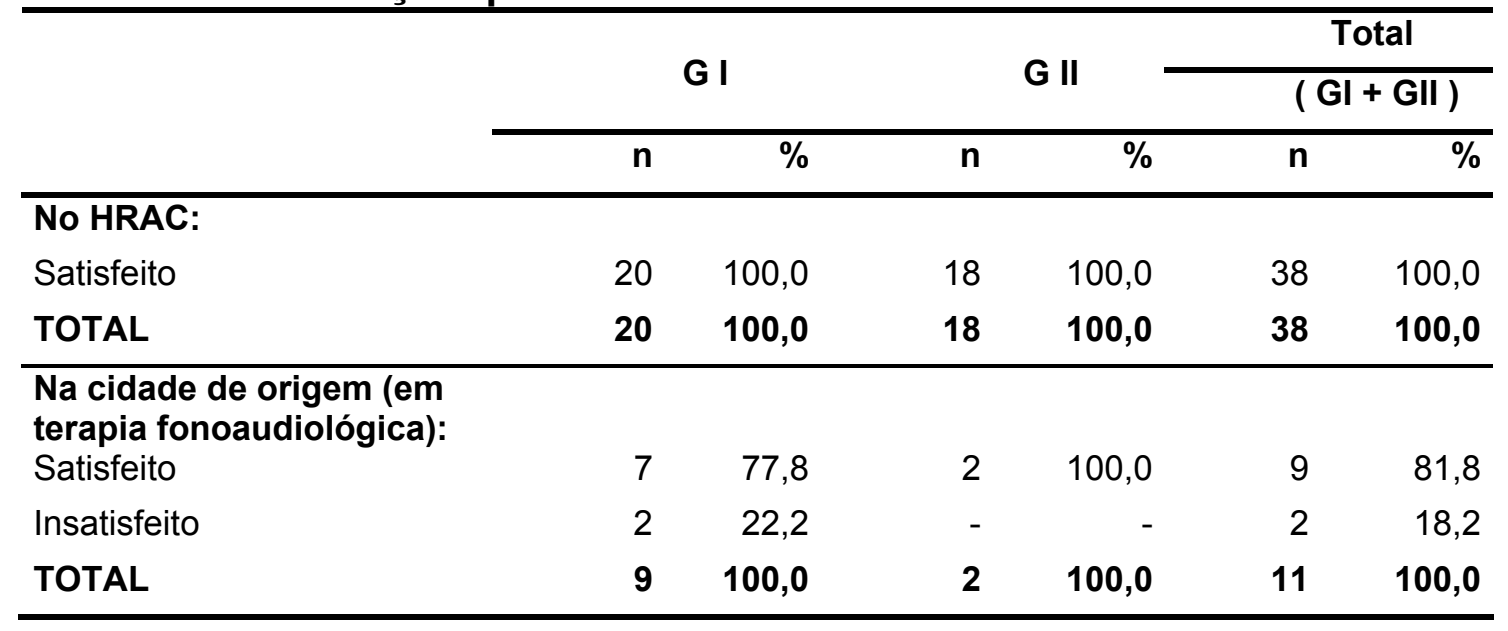

$\mathrm{Na}$ tabela 14 podemos observar que, o tratamento realizado pelos pacientes no HRAC atende às expectativas das famílias, sendo que a satisfação ocorre para $100,0 \%$ dos indivíduos do GI e GII, evidenciando o compromisso do hospital com a qualidade e humanização dos atendimentos.

A satisfação com o tratamento no HRAC é confirmada em várias pesquisas desenvolvidas, dentre as quais destacamos a realizada pela Ouvidoria do HRAC em 2003, cujo índice de satisfação atingiu a classificação de $94 \%$.

O HRAC deve buscar a promoção da qualidade de seus serviços, considerando na avaliação de seu desempenho, a satisfação dos usuários, que segundo Almeida (2001), significa conceber os serviços de saúde não como um fim, mas como meio de se atender às necessidades e expectativas sociais expressas pelas demandas de assistência à saúde.

Com relação ao tratamento fonoaudiológico realizado na cidade de origem, $81,8 \%$ o avaliaram de forma positiva, para uma minoria de insatisfeitos $(18,2 \%)$.

Esses dados sugerem ocorrer nos últimos anos uma mudança no comportamento do usuário de serviço público, no caso a saúde, que busca participar e avaliar mais efetivamente o atendimento, como um direito.

Considerando que os programas de atenção à saúde precisam de processos avaliativos que possibilitem a reflexão e que a avaliação da satisfação do usuário representa uma forma de adequar o atendimento, tanto 
os profissionais como as instituições devem manter serviços constantes de avaliação.

Os dados da tabela 14 não permitiram a aplicação de testes estatísticos em virtude da unanimidade de satisfação quanto ao tratamento realizado no HRAC e do menor índice de pacientes para o grupo II com relação a satisfação com a terapia fonoaudiológica na cidade de origem. 


\section{CONCLUSÕES.}

Considerando que na análise dos resultados deste estudo, sobre os aspectos psicossociais de indivíduos com e sem distúrbios da comunicação, não encontramos na maioria das categorias, diferenças significativas entre os dois grupos pesquisados, apresentaremos as conclusões com base na totalidade da amostra. Somente as categorias que apresentarem diferenças entre os grupos serão destacadas.

Com relação ao perfil socioeconômico e geográfico, a maioria dos pacientes é procedente da região sudeste e pertencente aos estratos sociais baixos, reflexo tanto da realidade do HRAC como da realidade brasileira.

$\mathrm{Na}$ interrelação entre os diferentes estratos socioeconômicos e o desenvolvimento da fala (pacientes com e sem distúrbio da comunicação) parece não haver relação direta entre ambos. Entretanto os resultados indicaram condições socioeconômicas relativamente melhores no Gl do que no GII.

No histórico e dinâmica familiar observamos:

- Situação conjugal e religiosa da família com predominância do estado civil casado, com vida comum estável e religião católica.

- Planejamento familiar com famílias compostas de 4 filhos, sendo que na maioria, o primogênito é portador de fissura labiopalatina e, a decisão de não ter mais filhos não ocorreu em função do nascimento do paciente, mas sim a fatores profissionais, financeiros e outros.

- Quanto a gestação e nascimento, destacou-se o diagnóstico da fissura informado na época do nascimento pelos médicos, evidenciando o não acesso a ultrassonografia como instrumento de diagnóstico precoce.

- Com maior índice para as mães, as reações dos pais em função do nascimento da criança com fissura labiopalatina foram negativas (susto, desespero, depressão, choque, rejeição e outros), mas superadas.

- As principais dificuldades encontradas no nascimento foram com relação a alimentação, tratamento, gastos decorrentes e falta de informações sobre os serviços de reabilitação. 
- As causas da ocorrência da fissura labiopalatina atribuídas pelos pais, foram tanto as ambientais e genéticas, como as culturais, referidas na literatura.

- A fissura labiopalatina é denominada pelos pais como malformação, "lábio leporino", termo esse mais popular para se referir às fissuras.

- Situações conflituosas conjugais marcaram a fase do nascimento da criança com fissura labiopalatina, superadas posteriormente com a retomada da união do casal.

- O significado de ter um filho com fissura labiopalatina foi considerado positivo pela maioria que ressaltou o despertar para uma realidade desconhecida e seu enfrentamento, bem como crescimento, amadurecimento pessoal, familiar, e religioso, especialmente diante da possibilidade de tratamento no HRAC.

Nas relações sociais da família destacamos:

- Que houve pouca diferença do índice de mães inseridas ou não no mercado de trabalho e, dentre as inseridas não se observou alteração na sua vida profissional após o nascimento. Entretanto, comparando os grupos individualmente observamos que no $\mathrm{Gl}$ (com distúrbios), o índice de mães que não trabalham foi estatisticamente significante ao comparar com o GII (sem distúrbios), sugerindo que a não inserção profissional não contribuiu para a redução do índice de distúrbios da comunicação.

- As atividades de lazer da família, quando alteradas, mesmo que para uma minoria, não ocorreram em virtude do nascimento do filho com fissura, e sim a outros fatores (familiares, financeiros e profissionais).

- Que os pais reagem em sua maioria com naturalidade frente a observação em público do filho com fissura, e apenas uma minoria demonstrou sentimento de tristeza.

- O diálogo dos pais com os pacientes, visando prepará-los para o tratamento e enfrentamento social foi destacado pela maioria.

Nas relações sociais do paciente observamos:

- O bom relacionamento na família e na escola com boa adaptação e facilidade de novas relações e convívio social, bem como a participação dos pais na vida escolar. No entanto, encontramos um índice significativo de 
crianças vítimas de chacotas no ambiente escolar, com destaque a apelidos preconceituosos.

- Comparando os grupos, no se refere a dificuldade de comunicação e relacionamento social, encontramos um índice estatisticamente significativo de dificuldades especialmente no ambiente escolar dos indivíduos no GI (com distúrbios).

- Os pais avaliaram as relações sociais do filho com fissura, nas diversas esferas, como positivo, reflexo dos resultados do tratamento, da participação da família e da sociedade, co-responsáveis no processo de reabilitação e inclusão social.

Nas intercorrências relacionadas ao tratamento fonoaudiológico na cidade de origem observamos:

- A expectativa de tratamento foi observada nas diferentes áreas, porém com maior destaque para as áreas de fonoaudiologia e estética/cirúrgica. Mesmo sem significância estatística, ao compararmos os grupos, o Gl (com distúrbio) apresentou um maior índice de expectativas nas áreas fonoaudiológica e odontológica, diretamente ligadas aos distúrbios da fala.

- A situação de tratamento dos indivíduos com indicação de terapia fonoaudiológica apresentou índices equilibrados entre as categorias: em terapia, alta e interrupção. Comparando os grupos quanto a situação de tratamento, houve significância estatística pois o Gl apresentou maior índice de indicação de terapia fonoaudiológica em função da presença de distúrbios da comunicação.

- Os casos que interromperam o tratamento fonoaudiológico o fizeram em virtude da: insatisfação com o atendimento (público); dificuldades financeiras para transporte; indisponibilidade de acompanhante; desativação, ausência e demanda reprimida para o acesso aos serviços; evidenciando a precariedade das políticas públicas no país, das quais a maioria da população (pobre) depende.

- A periodicidade e o tempo de duração das terapias fonoaudiológicas foram reduzidas, quando comparadas à recomendada, mais uma vez, em função da demanda reprimida do setor público que não tem cumprido seu dever constitucional e do qual a maioria depende. Somando a isto, observamos 
que a maioria assume as despesas com transporte, que também deveria ser de responsabilidade do poder público, previsto em leis municipais em observância a lei federal relacionada às pessoas portadoras de deficiência.

- A figura materna mais uma vez se destacou como acompanhante mais freqüente das crianças nas terapias, assim como na disponibilidade em realizar os exercícios no domicílio, reforçando a importância da participação da família no tratamento, especialmente da mãe com a qual mantém maior vínculo.

- A satisfação com o tratamento fonoaudiológico na cidade de origem foi manifestada pela maioria, entretanto, a insatisfação ainda que de uma minoria, está diretamente ligada a qualidade dos serviços públicos disponíveis.

Com relação aos recursos organizacionais e comunitários identificados destacou-se:

- A maioria dos pais não tinha conhecimento do HRAC, anteriormente ao nascimento do filho, sendo informada a respeito, por médicos das respectivas instituições (hospitais/maternidades).

- A concepção dos pais sobre os serviços prestados pelo HRAC, foi de direito para a maioria, evidenciando os resultados positivos da equipe de reabilitação e especialmente do Serviço Social em orientar os usuários a fazerem uso dos mesmos como cidadãos. Os que ainda concebem como favor, ou não se conscientizaram, ou não foram despertados para os direitos de cidadania, dentre eles a saúde, previstos na Constituição.

- Com relação aos recursos facilitadores e/ou viabilizadores do tratamento, na maioria dos municípios, observou-se uma diversidade a exemplo do TFD, coordenadores, Carona Amiga e, associações, como os mais conhecidos e utilizados pelos pacientes, evidenciando a importância do Serviço Social na mobilização de diferentes recursos humanos e institucionais extra-muros, para a garantia do processo de reabilitação.

- A satisfação como medida de avaliação da qualidade dos serviços é um dos compromissos do HRAC em respeito aos direitos dos pacientes, dentro de uma política de humanização e manifestada como positiva de forma unânime pelos indivíduos pesquisados. 
Diante do exposto, podemos afirmar que não foram constatadas relações significativas entre os resultados pós tratamento no que se refere a fala e a condição socioeconômica dos pacientes. Não foram também detectadas diferenças significativas entre os aspectos psicossociais e familiares entre os grupos com e sem distúrbios, exceto no cotidiano escolar de uma minoria de pacientes (com distúrbios), situação esta destacada na literatura. A escola, palco de novos desafios representa a mais importante experiência da criança fora do lar, onde será observada e julgada pela sua aparência física e por sua fala, nem sempre inteligível, em decorrência da fissura labiopalatina.

Embora algumas categorias não apresentassem significância estatística, todas configuraram-se como expressivas e determinantes para o conhecimento qualitativo dos aspectos psicossociais e familiares, e para a atuação da equipe de reabilitação que, com sua visão de totalidade, busca com os pais e a sociedade, a inclusão social do paciente.

Neste contexto, destaca-se a participação do Serviço Social, sempre buscando alternativas para o enfrentamento das questões sociais, numa perspectiva de cidadania, incentivando a prática participativa e organizativa dos indivíduos e familiares em defesa aos direitos das pessoas com deficiências, dentre elas, as com anomalias craniofaciais. 


\section{REFERÊNCIAS BIBLIOGRÁFICAS}




\section{REFERÊNCIAS BIBLIOGRÁFICAS.}

Almeida HM de S. Programa de qualidade do governo federal aplicado à saúde. Rev Adm Saúde 2001; 3:5-10.

Altmann EBC, Vaz ACN, Paula MBSF, Khoury RBF. Tratamento precoce. In: Altmann EBC. Fissuras labiopalatinas. 4a. ed. São Paulo: Pró-Fono; 1997. p.291-324.

Amaral VLAR do. Aspectos psicossociais. In: Altmann EBC. Fissuras labiopalatinas. 4a. ed. São Paulo: Pró-Fono; 1997. p.501-14.

Aries P (1978) apud Szymanski HRG. Trabalhando com famílias. São Paulo: Instituto de Estudos Especiais, Pontifícia Universidade Católica de São Paulo; 1992. (Cadernos de Ação; 1).

Barros AJS, Lehfeld NAS. Fundamentos de metodologia científica: um guia para a iniciação científica. 2a. ed. São Paulo: Makron Books; 2000.

Bauru. Estatuto Social. Rede Nacional de Associações de Pais e Portadores de Fissuras Lábio Palatais - REDE PROFIS [online] 16 de julho de 2004. $\begin{array}{llll}\text { [consultado fev. 2006] Disponível: } & \end{array}$ URL:http://www.redeprofis.com.br/estatuto.php.

Benjamin C. Reforma, nação e barbaria. Inscrita 1997; 1:7-14.

Bradley DP. Congenital and acquired velopharyngeal inadequacy. In: Bzoch $\mathrm{KR}$, editor. Communicative disorders related to cleft lip and palate. 4th. ed. Austin: Pro-Ed; 1997. p.223-43.

Brasil. Constituição 1988. Constituição da República Federativa do Brasil: promulgada em 5 de outubro de 1988. São Paulo: Imprensa Oficial do Estado; 1988. p.36-8 
Brasil. Estatuto da Criança e do Adolescente: Lei no 8.069 de 13 de julho de 1990. In: Legislação brasileira para o serviço social: coletânea de leis, decretos e regulamentos para instrumentação da (o) Assistente social/(organização Conselho Regional de Serviço Social do Estado de São Paulo, 9a Região Gestão 2002-2005). São Paulo: O Conselho; 2004c.

Brasil. Lei Federal n 8662 de 7 de junho de 1993. Dispõe sobre a profissão de assistente social e da outras providências. In: Legislação brasileira para o serviço social: coletânea de leis, decretos e regulamentos para instrumentação da (o) Assistente social/(organização Conselho Regional de Serviço Social do Estado de São Paulo, $9^{a}$ Região - Gestão 2002-2005). São Paulo: O Conselho; 2004d.

Brasil. Ministério da Saúde. Lei orgânica da Saúde: Lei n 8080 de 19 de setembro de 1990. Dispõe sobre as condições para a promoção, proteção e recuperação da saúde, a organização e o funcionamento dos serviços correspondentes e da outras providências. In: Legislação brasileira para o serviço social: coletânea de leis, decretos e regulamentos para instrumentação da (o) Assistente social/(organização Conselho Regional de Serviço Social do Estado de São Paulo, 9a Região - Gestão 2002-2005). - São Paulo: O Conselho; 2004.

Brasil. Ministério da Saúde. Secretaria de Assistência à Saúde. Atenção à pessoa portadora de deficiência no Sistema Único de Saúde: planejamento e organização de serviços. Brasília: Ministério da Saúde; 1993a.

Brasil. Ministério da Saúde. Secretaria de Assistência à Saúde. Portaria no 55 , de 24 de fevereiro de 1999: dispõe sobre a rotina do Tratamento Fora do Domicílio no Sistema Único de Saúde - SUS, com inclusão dos procedimentos específicos na tabela de procedimentos do Sistema de Informações Ambulatoriais do SAI/SUS. Diário Oficial [da República Federativa do Brasil] 1999; :26 
Brasil. Ministério da Saúde. Secretaria de Assistência à Saúde. Portaria $n^{\circ} 126$, de 17 de setembro de 1993. [...ficam desde já autorizados à realização dos procedimentos citados nesta portaria]. Diário Oficial [da República Federativa do Brasil]. Brasília, n.180, p.14084, 21 set. 1993. Seção I.

Brasil. Ministério da Saúde. Sistema Único de Saúde: Lei nº 8142 de 28 de dezembro de 1990. Dispõe sobre a participação da comunidade na gestão do Sistema Único de Saúde (SUS) e sobre as transferências intergovernamentais de recursos financeiros na área da saúde e da outras providências. In: Legislação brasileira para o serviço social: coletânea de leis, decretos e regulamentos para instrumentação da (o) Assistente social/(organização Conselho Regional de Serviço Social do Estado de São Paulo, $9^{a}$ Região Gestão 2002-2005). São Paulo: O Conselho; 2004b.

Brasil. Presidência da República. Casa Subchefia para Assuntos Jurídicos. Decreto $n^{\circ} 3.298$, de 20 de dezembro de 1999. Regulamenta a Lei $n^{\circ} 7.853$, de 24 de outubro de 1989, dispõe sobre a Política Nacional para a Integração da Pessoa Portadora de Deficiência, consolida as normas de proteção, e dá outras providências [online] [consultado em 02 jan. 2006a]. Disponível: URL:http://www.planalto.gov.br.

Brasil. Presidência da República. Casa Subchefia para Assuntos Jurídicos. Regulamenta as Leis $n^{\circ} 10.048$, de 8 de novembro de 2000 , que dá prioridade de atendimento às pessoas que especifica, e $n^{\circ} 10.098$, de 19 de dezembro de 2000, que estabelece normas gerais e critérios básicos para a promoção da acessibilidade das pessoas portadoras de deficiência ou com modalidade reduzida, e dá outras providências [online] [consultado em 02 jan. 2006b]. Disponível: URL:http://www.planalto.gov.br.

Bzoch KR. Etiological factors related to cleft palate speech. In: editor. Communicative disorders related to cleft lip and palate. 2nd. ed. Austin: Litle Brown; 2004. 
Camargo OP. Serviço Social: avaliação social. In: . Centro de estudos demográficos e perfil socioeconômico dos usuários do sistema de saúde do Estado de São Paulo: Datasaúde. São Paulo: Hospital das Clínicas, Faculdade de Medicina, Universidade de São Paulo; 2000. (Relatório Final FAPESP, processo $n^{\circ}$ 00/02056-3).

Capelozza Filho L, Silva Filho OG. Fissuras lábio-palatais. In: Petrelli NE, coordenador. Ortodontia para fonoaudiologia. Curitiba: Lovise; 1992. p.195239.

Capelozza Filho L, Alvares ALG, Rossato C, Vale DMV, Janson GRP, Beltrami LER. Conceitos vigentes na etiologia das fissuras labiopalatinas. Rev Bras Cirurg 1988; 78:233-40.

Cariola TC. Indicadores emocionais do desenho da figura humana realizados por crianças com fissuras lábio-palatais [tese]. Assis: Instituto de Letras, História e Psicologia de Assis, Universidade Estadual Paulista; 1985.

Chinellato MCMP. Troca de informações fortalece mães e bebês com problemas de má-formação. Jornal da Cidade 14 ago. 1994. p.10.

Chizzotti A. A coleta de dados quantitativos. In: Pesquisa em ciências humanas e sociais. 2a. ed. São Paulo: Cortez; 1995. p.51-87.

Critério de Classificação Econômica Brasil: CCEB. [online] [consultado em 2003];

Disponível:

URL:http://www.anep.org.br/pesquisaemfoco/dez2002/cceb.htm.

Em Foco. Boletim informativo do HRAC/USP e FUNCRAF. Bauru: Hospital de Reabilitação de Anomalias Craniofaciais, Universidade de São Paulo 2005; 5(37). 
Fávero ET. O estudo social fundamentos e particularidades de sua construção na área judiciária. In: Conselho Federal de Serviço Social, organizador. O estudo social em perícias, laudos e pareceres técnicos contribuição ao debate judiciário, penitenciário e na previdência social. São Paulo: Cortez; 2003. p.423.

Ferrari MAC, Damasceno MCP. Reabilitação. Cadernos [online] [consultado em 27 dez. 2005]; 10(1). Disponível: URL: http://www.scamilo.edu.br/inside.php?page=servicos\&tema=publi_editorial\&ID= 16.

Ferreira $\mathrm{ABH}$. Novo dicionário da língua portuguesa. 2a. ed. Rio de Janeiro: Nova Fronteira; 1975.

Forte MJP. O adolescente e a família. Pediatria (São Paulo) 1996; 18:157-61.

Freitas JAS. Centro de Pesquisa e Reabilitação de Lesões Lábio Palatais. Bauru: Faculdade de Odontologia de Bauru, Universidade de São Paulo; 1974.

Frossard A, Matos M. Algumas reflexões sobre a prática do assistente social na saúde. In: Caderno de comunicações do $9^{\circ}$ Congresso Brasileiro de Assistentes Sociais; 1998. Goiânia, Brasil. Goiânia: Conselho Federal de Serviço Social; 1998. p.119-22.

Gil AC. Métodos e técnicas de pesquisa social. 2a. ed. São Paulo: Atlas; 1989.

Graciano MIG. De cliente a agente: os pais coordenadores e a sua ação multiplicadora num programa com portadores de lesões lábio-palatais [dissertação]. São Paulo: Pontifícia Universidade Católica de São Paulo; 1988.

Graciano MIG. Critérios de avaliação para classificação socio-econômica. Serv Social_Soc 1980; 1:81-103. 
Graciano MIG, Custódio SAM, Blattner SHB, Garcia RCM. Os programas do serviço social do Hospital de Reabilitação de Anomalias Craniofaciais/USP na atualidade. Const Serv Social 2001; 8:43-50.

Graciano MIG, Lehfeld NAS, Neves Filho A. Critérios de avaliação para a classificação sócio-econômica: elementos de atualização. Serv Soc Real 1999; 8:109-28.

Graciano MIG, Lehfeld NAS, Neves Filho A. Critérios de avaliação para classificação socio-econômica: elementos de atualização - parte II. Serv Soc Real 1996; 5:171-201.

Graciano MIG, Blattner SHB, Custódio SAM, Garcia RCM, Camargo RB, Formenti NS, et al. Plano de ação do serviço social: área de anomalias craniofaciais, 2003-2006. Bauru: Hospital de Reabilitação de Anomalias Craniofaciais, Universidade de São Paulo; 2003.

Graciano MIG, Blattner SHB, Lourenção CM, Custódio SAM, Mesquita ST, Garcia RCM, et al. O perfil social de portadores de fissuras labiopalatais em projeto de pesquisa interdisciplinar da Universidade de São Paulo e Universidade da Flórida. Bauru: Hospital de Reabilitação de Anomalias Craniofaciais, Universidade de São Paulo; 2004.

Gurvitch G (1996) apud Gohn MC. Classes sociais e movimentos sociais. In: Capacitação em serviço social e política social: Módulo 2. Crise contemporânea, questão social e serviço social. Brasília: CEAD; 1999. p.36-54.

Instituto Brasileiro de Geografia e Estatística. Censo Demográfico 2000. [online] [consultado em 30 dez. 2005]. Disponível: URL:http://www.ibge.gov.br/censo/default.php. 
Instituto Brasileiro de Geografia e Estatística. Pesquisa nacional por amostra de domicílios. Trabalho. [online] [consultado em 26 jan. 2006]. Disponível: URL:http://www.ibge.gov.br/brasil_em_sintese/tabelas/trabalho.htm.

Instituto Brasileiro de Geografia e Estatística. Síntese de indicadores sociais 2002. [online] [consultado em 5 nov. 2003]. Disponível: URL:http://www.ibge.gov.br/home/presidencia/noticias/12062003indic2002.sht $\mathrm{m}$.

Jones JE. Self-concept and parental evaluation of peer relationships in cleft lip and palate children. Pediatr Dent 1984; 6:132-8.

José Filho M. A família como espaço privilegiado para a construção da cidadania. Franca: Faculdade de História, Direito e Serviço Social, Universidade Estadual Paulista; 2002.

Kaloustian SM, organizador. Família brasileira, a base de tudo. São Paulo: Cortez; 1994.

Lakatos EM, Marconi MA. Metodologia científica. 2a. ed. São Paulo: Atlas; 1991.

Lansdown R. Cleft lip and palate: a prediction of psychological disfigurement? Br J Orthod 1981; 8:83-8.

Mac Gregor FC. Transformation and identity: the face and plastic surgery. New York: New Times Book; 1974.

Martinelli ML, Koumrouyan E. Um novo olhar para a questão dos instrumentos técnicos operativos em serviço social. Serv Social Soc 1994; 15:137-41.

Mesquita ST. As repercussões sociais das malformações congênitas lábiopalatais no cotidiano de seus portadores. Bauru: Hospital de Pesquisa e 
Reabilitação de Lesões Lábio-Palatais, Universidade de São Paulo; 1991. (Relatório Final CNPq - período de março/90 a julho/91 - processo $\mathrm{n}^{\circ}$ 821013/88-2).

Mesquita ST. (Re)conhecendo os hospitais de alta complexidade na área de lesões labiopalatais e a presença do serviço Social: um retrato do Brasil [tese]. Franca: Universidade Estadual Paulista; 2005.

Minayo MCS. Ciência, técnica e arte: o desafio da pesquisa social. In: Minayo MCS, organizadora. Pesquisa social: teoria, método e criatividade. 7a. ed. Petrópolis: Vozes; 1994. p.22-3.

Morris HL. Velopharyngeal competence and primary cleft palate surgery, 19601971: a critical review. Cleft Palate J 1973; 10:62-71.

Nagem Filho H, Moraes N, Rocha RGF. Contribuição para o estudo da prevalência das más formações congênitas lábio-palatais na população escolar de Bauru. Rev Fac Odontol Univ São Paulo 1968; 6:111-28.

Nelli EA, Vicente MCZ, Buchala RG, Buffa MJMB, Souza RF. Ações integradas na reabilitação de crianças portadoras de lesões labiopalatais. In: Kudo AM, Marcondes E, Lins L, Moriyama LT, Guimarães MLLG, Juliani RCTP, et al. Fisioterapia, fonoaudiologia e terapia ocupacional em pediatria. São Paulo: Sarvier; 1990. p.309-26.

Neves P, Paixão R. Família e deficiência mental. Caesura, 1994; 5:70-80.

Noronha JC, Lima LD, Machado CV. A gestão do sistema único de saúde: características e tendências. In: Saúde no Brasil: contribuições para a agenda de prioridades de pesquisa. Brasília: Ministério da Saúde; 2004. p.45-94.

Oliveira PA. A investigação diagnóstica de famílias de pacientes casos novos do Hospital de Pesquisa e Reabilitação de Lesões Lábio-Palatais, Universidade 
de São Paulo: estudos de casos [monografia]. Bauru: Faculdade de Serviço Social, Instituição Toledo de Ensino; 1992.

Pannbacker M, Scheuerle J. Parents' attitudes toward family involvement in cleft palate treatment. Cleft Palate Craniofac. J. 1993; 30:87-9.

Paynter ET, Edmonson TW, Jordan WJ. Accuracy of information reported by parents and children evaluated by a cleft palate team. Cleft Palate Craniofac $J$ 1991; 28:329-37.

Pegoraro-Krook MI, Williams WN. Função velofaríngea para a fala após a palatoplastia. Bauru: Hospital de Reabilitação de Anomalias Craniofaciais, Universidade de São Paulo, Universidade da Flórida; 1995.

Pertschuk MJ, Whitaker LA. Psychosocial adjustment and craniofacial malformations in childhood. Plast. Reconstr. Surg. 1985; 75:177-84.

Poster M (1979) apud Szymanski H. Trabalhando com família. São Paulo: Instituto de Estudos Especiais, Pontifícia Universidade Católica de São Paulo; 1992.

Rego JD. Assistência aos pais de recém-nascidos doentes e/ou malformados. In: Miranda LEV, Lopes JMA, coordenadores. Manual de perinatologia. Rio de Janeiro: Sociedade Brasileira de Peridiatria; 1990. p.103-11.

Riski JE. Articulation skills and oral-nasal resonance in children with pharyngeal flaps. Cleft Palate J 1979; 16:421-8.

Rodrigues On ML. O serviço social e a perspectiva interdisciplinar. In: Martinelli $\mathrm{ML}$, Rodrigues ML, Muchail ST, organizadoras. O uno e múltiplo nas relações entre as áreas do saber. São Paulo, Cortez; 1995. p.152-8 
Sampaio CC, Rossi D, Biajoni M do C, Colodo M, Tacco MAC, Savassi TR. Interdisciplinaridade em questão: análise de uma política de saúde voltada à mulher. In: Sá JLM. Serviço social e interdisciplinaridade: dos fundamentos filosóficos à prática interdisciplinar no ensino, pesquisa e extensão. São Paulo: Cortez; 1989. p.77-95.

Sarmento HBM Instrumentos e técnicas em serviço social: elementos para uma rediscussão [dissertação]. São Paulo: Pontifícia Universidade Católica de São Paulo; 1994.

Sassaki RK. Os novos paradigmas. In: Sassaki RK. Inclusão: construindo uma sociedade para todos. Rio de Janeiro: WVA; 1997. p.27-57.

Seagle MB. Primary surgical correction of cleft palate. In: Bzoch KR, editor. Communicative disorders related to cleft lip and palate. 5th. ed. Austin: Pro-Ed.; 2004 p.181-92.

Silva Filho OG, Ferrari Junior FM, Rocha DL, Freitas JAS. Classificação das fissuras lábio-palatais: breve histórico, considerações clínicas e sugestão de modificação. Rev Bras Cir 1992; 82:59-65.

Silva ML, Lessa SZG. Práticas de serviço social na área hospitalar: o que mudou. In: Silva JO, organizadora. Práticas do serviço social: espaços tradicionais e emergentes. Porto Alegre: Decasa; 1998. p.117-30.

Suguimoto MLFCP. Análise da fala de indivíduos operados de palato, entre 12 e 24 meses de idade: estudo retrospectivo [dissertação]. Bauru: Hospital de Reabilitação de Anomalias Craniofaciais, Universidade de São Paulo; 2002.

Szymanski HRG. Trabalhando com famílias. São Paulo: Cortez, Instituto de Estudos Especiais, Pontifícia Universidade Católica de São Paulo; 1992. (Cadernos de Ação; 1). 
Triviños ANS. Introdução à pesquisa em ciências sociais: a pesquisa qualitativa em educação. São Paulo: Atlas; 1995.

Yamada MO. A construção da deficiência auditiva na família [monografia]. Bauru: Instituto Bauruense de Psicodrama; 1998. 


\section{FICHA DO SERVIÇO SOCIAL}

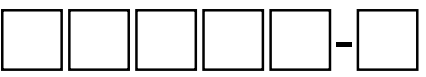

I - INVESTIGAÇÃO DIAGNÓSTICA

01 - CLASSIFICAÇÃO SÓCIO-ECONÔMICA:
( ) N/C
( ) $\mathrm{F}-\mathrm{BI}$
( ) $\mathrm{E}-\mathrm{BS}$
( ) $\mathrm{D}-\mathrm{MI}$
$30-40$
( $)$ C $-M$
( ) B - MS
$47-54$
( $) \mathrm{A}-\mathrm{AL}$ $54-57$

TOTAL PONTOS:

OBS.: Alteração da Tabela ( ) SIM （）NÃO Esp.:

02 - Situação econômica da família salários mínimos

\begin{tabular}{|c|c|c|c|c|}
\hline PONTOS & \multicolumn{4}{|c|}{ Renda bruta mensal } \\
\hline 21 & ) & acima d & 100 & SM \\
\hline 18 & ) & 60,1 & & 0 SM \\
\hline 14 & & 30,1 & & $0 \mathrm{SM}$ \\
\hline 12 & ) & 15,1 & 30 & SM \\
\hline 9 & ) & 9,1 & 15 & SM \\
\hline 5 & ) & 4,1 & 09 & SM \\
\hline 3 & ) & 2,1 & 04 & SM \\
\hline 2 & & $1 / 2$ & 02 & SM \\
\hline 1 & ) & $0 \mathrm{H}$ & $1 / 2$ & SM \\
\hline
\end{tabular}

Tipo de rendimento:
( ) salário ( ) retirada pró-labore
( ) aposentadoria
( ) pensionista
( ) rendimento financeiro ( ) aluguéis
( ) honorários

03 - Número de membros residentes da família / Especificação pessoas PONTOS
6
( ) até 2
( ) $2+4$
( ) $4-6$
( ) $6-8$
1 ( ) acima de 8

04 - Escolaridade Maior nível educacional / responsável * PONTOS *

7
5
4
3
2
1
0
$N$

Nível educacional

$$
\begin{aligned}
& \text { ) 1-Superior } \\
& \text { 2-Superior incompleto / 3- médio completo } \\
& \text { 4-médio incompleto / } 5 \text { - fundamental II completo } \\
& \text { 6- fundamental II incompleto / 7-fundamental I } \\
& \text { completo } \\
& \text { 8- fundamental I incompleto } \\
& \text { 9- sem escolaridade / alfabetizado } \\
& \text { 10- sem escolaridade / analfabeto } \\
& \text { 11- sem idade escolar } \\
& \text { 12- (ensino infantil) }
\end{aligned}
$$

\section{5 - Habitação / Situação}

\section{6 - Habitação / Condição.}

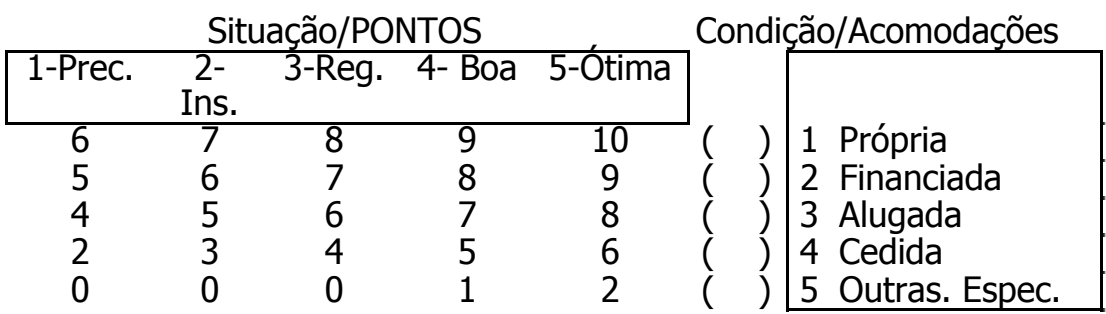

Obs.: Número de Cômodos
Especificação/Vínculo/Relações

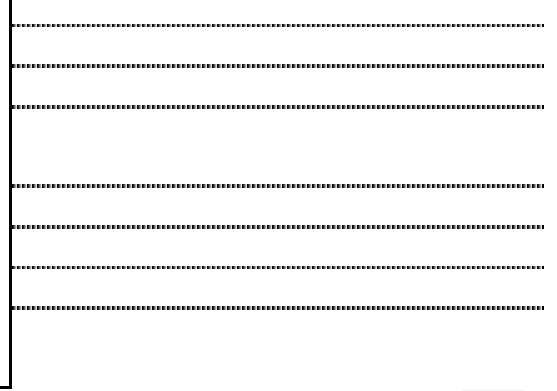

Especificação

Especificação/Relações (religião) 
07 - Tipo:

( ) 1-tijolos ( ) 2- madeira ( ) 3-tijolos e madeira ( ) 4- outros. Espec:

08 - Zona (localização)

( ) 1-Rural ( ) 2-Urbana 1 ( ) 3-Suburbana

09 - Infra-estrutura:

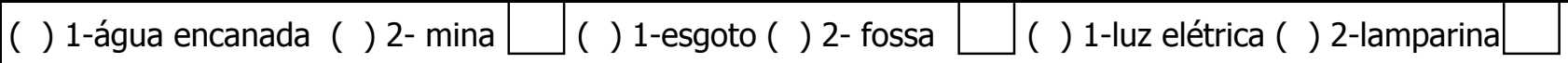

\section{0 - Nível Ocupacional}

( ) 1 -Ativo ( ) 2-Aposentado ( ) 3 -Pensionista ( ) 4-Desempregado .....

Ocupação - Maior nível ocupacional / responsável. PONTOS

13 ( ) 1- Empresários

11 ( ) 2- Trabalhadores da alta administração

10 ( ) 3- Profissionais liberais autônomos

9 ( ) 4- Trabalhadores assalariados administ., técnico e científicos

7 ( ) 5- Trabalhadores assalariados

6- Trabalhadores por conta própria/autônomos:

7 ( ) Com empregado

6 ( ) 7- Sem empregado

8- Pequenos produtores rurais:

5 ( ) Com empregado

3 ( ) 9- Sem empregado

10-Empregados Domésticos:

3 ( ) Urbano

2 ( ) 11- Rural

1 ( ) 12- Trabalhadores rurais assalariados, volantes e assemelhados

\section{Especificação/Vínculo/Relações}

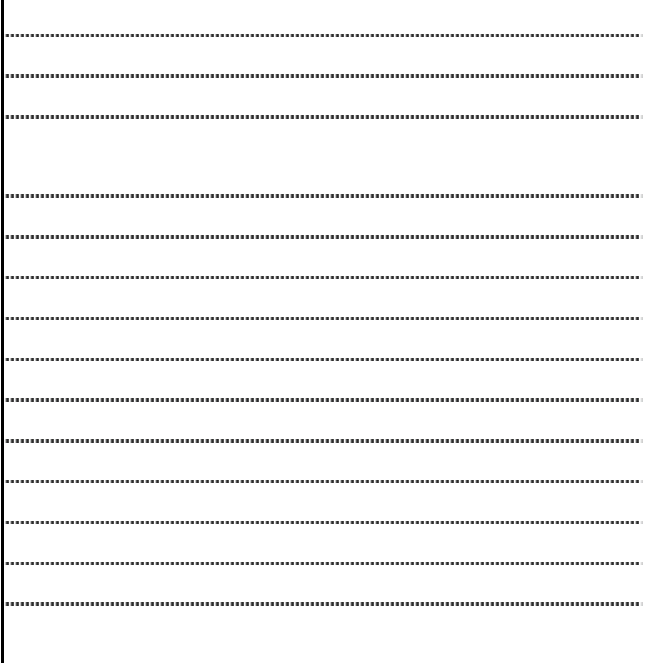

11 - Setor:

( ) 1 - Primário (recursos da natureza)

( ) 3 - Terciário (comércio e prestação de serviços)

OBS: ( ) 1 - Público ( ) 2 - Privado

\section{II - Recursos para Reabilitação}

Cidade / Estado (trajeto)

Recursos para retornos (próprio, C.A., A.T.F.D., Coordenadores, Associações)

Hs ou Km:

Prazo para comunicação de retorno:

Periodicidade dos retornos:

Recursos para tratamento local (odonto, fono, etc, )

Expectativas:

Problemas de saúde ou deficiências:

III - Parecer/Intervenção do Serviço Social:

Data: 1

ASSISTENTE SOCIAL:

Código CPD 
ANEXO 2 - Configuração dos estratos sociais de usuários do HRAC/USP

\begin{tabular}{|c|c|c|c|c|c|}
\hline $\begin{array}{l}\text { Indicadores } \\
\text { Estratificação }\end{array}$ & $\begin{array}{l}\text { Situação } \\
\text { Econômica }\end{array}$ & $\begin{array}{l}\text { Membros } \\
\text { (pessoas) }\end{array}$ & Escolaridade & $\begin{array}{l}\text { Habitação } \\
\text { situação }\end{array}$ & Ocupação \\
\hline $\begin{array}{l}\text { Baixa } \\
\text { Inferior } \\
8394(27,8 \%)\end{array}$ & $\begin{array}{l}\text { de } 1 / 2 \text { a } 2 \text { SM: } 62 \% \\
\text { de } 2 \text { a } 4 \text { SM: } 26 \%\end{array}$ & $\begin{array}{l}2 \text { a } 4: 40 \% \\
5 \text { a } 6: 34 \%\end{array}$ & $\begin{array}{l}\text { Prim.Inc. e Comp.:48\% } \\
\text { Gin. Inc. e Comp. } 27 \%\end{array}$ & $\begin{array}{l}\text { Cedida: } 42 \% \\
\text { Própria: } 36 \% \\
\text { Regular } 37 \% \\
\text { Pree. e Insat. } \\
48 \%\end{array}$ & $\begin{array}{l}\text { Emp. Dom. 27\% } \\
\text { Trab. Assal./ } \\
\text { Prod: 18\% } \\
\text { Trab. Rur. } \\
\text { Assal./Vol. 34\% }\end{array}$ \\
\hline $\begin{array}{l}\text { Baixa } \\
\text { Superior } \\
\mathbf{1 6 6 9 0}(\mathbf{5 5 , 3 \% )}\end{array}$ & $\begin{array}{l}\text { de } 4 \text { a } 9 \text { SM: } 36 \% \\
\text { de } 2 \text { a } 4 \text { SM: } 40 \%\end{array}$ & $\begin{array}{l}2 \text { a } 4: 52 \% \\
5 \text { a } 6: 30 \%\end{array}$ & $\begin{array}{l}\text { Prim. Com. e Inc. } 29 \% \\
\text { Gin. Comp. e Inc. } 30 \% \\
\text { Col. Comp. e Inc. } 32 \%\end{array}$ & $\begin{array}{l}\text { Própria: 57\% } \\
\text { Regular. } 44 \% \\
\text { Boz. } 38 \%\end{array}$ & $\begin{array}{l}\text { Trab. Assal./ } \\
\text { Prod. 66\% } \\
\text { Trab. Aut. 26\% }\end{array}$ \\
\hline $\begin{array}{l}\text { Média } \\
\text { Inferior } \\
4239(14,1 \%)\end{array}$ & $\begin{array}{l}\text { de } 4 \text { a } 9 \text { SM: } 27 \% \\
\text { de } 9 \text { a } 15 \text { SM: } 42 \%\end{array}$ & $\begin{array}{l}2 \text { a } 4: 56 \% \\
5 \text { a } 6: 28 \%\end{array}$ & $\begin{array}{l}\text { Col. Comp. e Inc. } 34 \% \\
\text { Sup. Comp. e Inc. } 48 \%\end{array}$ & Própria: $70 \%$ & $\begin{array}{l}\text { Trab. Assal./ Prod. } \\
41 \% \\
\text { Trab. Assal. Adm. } \\
\text { Téc. Cien. 29\% } \\
\text { Trab. Aut. 21\% }\end{array}$ \\
\hline $\begin{array}{l}\text { Média } \\
779(2,6 \%)\end{array}$ & 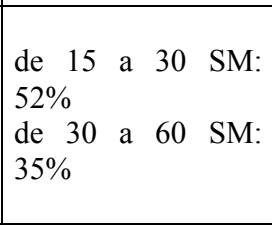 & $\begin{array}{l}2 \text { a } 4: 59 \% \\
5 \text { a } 6: 28 \%\end{array}$ & Sup. Comp. 83\% & $\begin{array}{l}\text { Própria: } 78 \% \\
\text { Ótima: } 50 \% \\
\text { Boa: } 44 \%\end{array}$ & $\begin{array}{l}\text { Prof. Lib. Aut. 29\% } \\
\text { Trab. Assal. Adm. } \\
\text { Téc. Cien. 39\% }\end{array}$ \\
\hline $\begin{array}{l}\text { Média } \\
\text { Superior } \\
62(0,2 \%)\end{array}$ & $\begin{array}{l}\text { de } 30 \text { a } 60 \text { SM: } \\
24 \% \\
\text { de } 60 \text { a } 100 S M: \\
58 \% \\
\end{array}$ & $\begin{array}{l}2 \text { a } 4: 50 \% \\
5 \text { a } 6: 34 \%\end{array}$ & Sup. Comp. 81\% & \begin{tabular}{|l} 
Própria: $77 \%$ \\
$\begin{array}{l}\text { Otima: } 75 \% \\
\text { Boa: } 21 \%\end{array}$ \\
\end{tabular} & $\begin{array}{l}\text { Prof. Lib. Aut. } \\
\text { 35\% } \\
\text { Empresário 28\% }\end{array}$ \\
\hline $\begin{array}{l}\text { Alta } \\
\mathbf{5}(\mathbf{0 , 0 1 \% )}\end{array}$ & $\begin{array}{l}\text { De } 60 \text { a } 100 \text { SM: } \\
60 \% \\
\text { acima de100 } \\
40 \%\end{array}$ & $\begin{array}{l}\text { de } 2 \text { a } 4: \\
80 \%\end{array}$ & Sup. Comp. $80 \%$ & $\begin{array}{l}\text { Própria: } 80 \% \\
\text { Ótima: } 80 \%\end{array}$ & $\begin{array}{l}\text { Empresário 60\% } \\
\text { Trab. Alta Adm. } \\
40 \%\end{array}$ \\
\hline
\end{tabular}

Estudo Baseado em 30.169 pacientes, com dados do Centro de Processamento de Dados do HRAC - março de 2005 de acordo com a metodologia desenvolvida por Graciano, Lehfeld, Neves Filho, 1999

\section{Legenda:}

SM: salário mínimo

Prim. Inc. e Comp.: primário incompleto e completo Gin. Inc. e Comp.: ginásio incompleto e completo

Col. Inc. e Comp.: colegial incompleto e completo

Sup. Comp.: superior completo
Prec./Insat.: precária/insatisfatória Trab. Assal./Prod.: trabalhador assalariado/produção de bens e serviço Trab. Assal. Adm. Téc. Cien.: trabalhador assalariado administrativo técnico-científico

Prof. Lib. Aut.: profissional liberal autônomo
Trab. Alta Adm.: trabalhador da alta administração

Emp. Dom. Urb.: empregado doméstico urbano

Trab. Rur. Assal.: trabalhador rural assalariado

Trab. Aut.: trabalhador autônomo 
ANEXO 3 - Aprovação pela Banca Examinadora da Pré-Qualificação

HOSPITAL de REABILITACĀO

DE ANOMALIAS CRANIOFACIAIS

UNMERSIDNDE OE SHO PUNO

SECRETARIA DE POS-GRUDUACG10

26/MARÇO/2004

OF. no 82-PG

Ilma. Sra.

Regina Célia Meira Garcia

HRAC-USP

Bauru - SP

Senhora,

Informamos que, segundo relatório apresentado pela banca examinadora da Pré-Qualificação realizada por V.Sa. em 15/3/2004, o resultado do seu exame foi "APTO".

Atenciosamente,

Profa. Dra. Inge Elly Kiemle Trindade

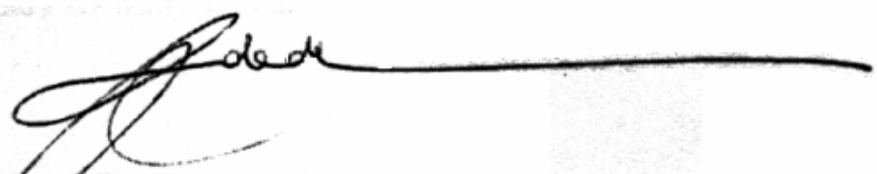

Presidente da Comissão de Pós-Graduação do HRAC-USP 
ANEXO 4 - Aprovaçăo do Comitê de Ética em Pesquisa

Ofício $n^{\circ}$ 002/2006-UEP-CEP

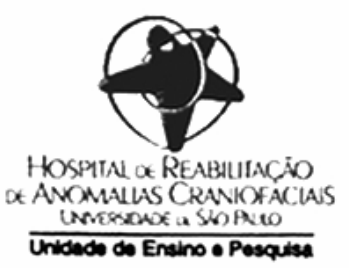

Bauru, 27 de janeiro de 2006.

Prezado(a) Senhor(a)

O projeto de pesquisa intitulado "Aspectos psicossociais e familiares de pessoas com e sem distúrbios da comunicação decorrentes da fissura labiopalatal", de autoria de REGINA CÉLIA MEIRA GARCIA desenvolvido sob sua orientação, foi aprovado pelo CEP em 25 de agosto de 2004. Em 27/01/2006 a solicitação de alteração do título para "Aspectos psicossociais e familiares de individuos com e sem distúrbios da comunicação decorrentes da fissura labiopalatina" foi aprovada.

Informamos que após o recebimento do trabalho concluído, este Comitê enviará um parecer final que poderá ser utilizado para publicação.

Atenciosamente

PROF. DR. ROBERTO LOUREIROMARINGONI

Coordenador do Comitê de Ética em Pesquisa do HRAC-USP

Ilma. Sra.

Dra. Maria Inês Gândara Graciano

Serviço Social - HRAC/USP 
UNIVERSIDADE DE SÃO PAULO

HOSPITAL DE REABILITAÇÃO DE ANOMALIAS CRANIOFACIAIS

\section{FORMULÁRIO}

\section{I - IDENTIFICAÇÃO DO PACIENTE}

Nome: Sexo:

RG: D.N. Idade Atual: Classe social:

Cidade: Estado: Distância:

Intercorrências no tratamento (frequência, histórico clínico/sociais no seguimento):

Entrevistado:

( ) pais

( ) mãe

( ) pai

( ) outros

II - ASPECTOS PSICOSSOCIAIS, CULTURAIS E FAMILIARES

\subsection{HISTÓRICO E DINÂMICA FAMILIAR}

SITUAÇÃO CONJUGAL E RELIGIÃO

01 . Qual é o estado civil dos pais?

( ) casados ( ) solteiros

Especifique:

( ) civil

( ) religioso

( ) Vida em comum há anos

02 . Qual é a religião dos pais?
( ) católica
( ) evangélica
( ) espírita
( ) sem religião
( ) outras

Especifique:

\section{GESTAÇ̃̃O E NASCIMENTO}

03. Quando vocês tiveram conhecimento sobre a ocorrência da fissura e quais foram as reações?
3.1. Época:
( ) durante a gravidez - ultrassom
( ) após o nascimento

3.2. Informante:

( ) médico

( ) enfermeira

( ) família

( ) outros

Especifique:

3.3. Reações dos pais: ( ) positivas ( ) negativas

Especifique:
3.4. Sentimentos de culpa:
( ) $\operatorname{sim}$ ( ) não

Especifique: 
continuação

3.5. Repercussões no relacionamento dos pais em decorrência da fissura:

antes do nascimento

no nascimento

atualmente

união

( )

( )

( )

conflito

( )

( )

( )

outros

( )

( )

( )

Obs:

3.6. Vocês tiveram outras dificuldades na ocasião do nascimento de seu filho ?
( ) $\operatorname{sim}$
( ) não

Especifique:

04. Qual a causa atribuída pelos pais pela ocorrência da FLP?
( ) genético
( ) ambiental
( ) cultural
( ) outros

05 . Como vocês denominam o problema?
( ) malformação
( ) lesão
( ) fissura
( ) goela de lobo
( ) lábio leporino
( ) outros Espec.

06. O que significa para você ter um filho portador de fissura:

\section{PLANEJAMENTO FAMILIAR:}

07. Qual é o $\mathrm{n}^{\mathrm{o}}$ de filhos do casal e a ordem do nascimento do paciente:

08. Vocês pretendem ter mais filhos? ( ) sim ( ) não ( ) indecisos

09. Vocês usam algum método anticonceptivo? ( ) sim ( ) não

Especifique: ( ) anticoncepcional ( ) esterilização feminina

( ) esterilização masculina ( ) outros

10. A decisão em não ter mais filhos ocorreu após o nascimento do paciente?
( ) $\operatorname{sim}$
( ) não

Especifique:

11. Vocês tem receio em ter outro filho com algum problema? ( ) sim

( ) não Porque:

12. Vocês receberam orientação do setor de genética do hospital?
( ) $\operatorname{sim}$
( ) não
( ) não lembra

Obs. 
continuacão

\subsection{RELAÇÕES SOCIAIS DO PACIENTE/FAMÍLIA}

13. Atualmente a mãe trabalha fora? ( ) $\operatorname{sim} \quad$ ( ) não
13.1. Qual o período:
( ) integral ( ) parcial

14. Houve alteração na vida profissional da mãe em função do nascimento do filho
com fissura?
( ) $\operatorname{sim}$
( ) não

Especifique:

15. O paciente fica a maior parte do tempo sob os cuidados de quem?
( ) mãe
( ) pai
( ) avós
( ) tios
( ) babá

( ) empregada ( ) irmãos ( ) outros Espec.

16. O paciente freqüente escola atualmente? ( ) $\operatorname{sim}$ ( ) não

16.1. Tipo: ( ) creche ( ) pré escola ( ) ensino fundamental

16.2. Série: 16.3. Idade inicial:

17. Comente sobre a adaptação e o relacionamento do paciente na escola:

18. Há participação da família na vida escolar do paciente? ( ) sim ( ) não

Comente:

19. Seu filho tem algum apelido relacionado à fissura? ( ) $\operatorname{sim}($ ) não Especifique:

20. Vocês conversam com a criança sobre o problema e o prepara para a vida social?
( ) $\operatorname{sim}$
( ) não
( ) às vezes

Especifique:

21. Quais eram as principais atividades de lazer da família antes do nascimento do paciente?

( ) visita a parentes/amigos ( ) shopping ( ) igreja ( ) passeios

( ) clube ( ) outros: espec.

22. Atualmente quais são as principais atividades de lazer da família?

( ) visita a parentes/amigos ( ) shopping ( ) igreja ( ) passeios

( ) clube ( ) outros: espec.

23. Comparando essas épocas e atividades 21 e 22, houve alterações após o nascimento?

( ) $\operatorname{sim}$ ( ) não Porque?

24. Como vocês reagem quando os filhos são observados em lugares públicos?

( ) naturalmente ( ) indiferente ( ) negativamente

Comente:

continua 
continuação

25. Seu filho apresenta dificuldades de comunicação e/ou relacionamento social em decorrência da fissura?

( ) $\operatorname{sim}$

( ) não

25.1. Especifique as áreas:
escola
( ) $\operatorname{sim}($ ) não
família
( ) $\operatorname{sim}($ ) não
social
( ) $\operatorname{sim}$ ( ) não
outros
( ) $\operatorname{sim}($ ) não

Especifique

26. Como é o relacionamento de seu filho com:

\begin{tabular}{|l|l|l|l|}
\hline & Bom & Regular & Ruim \\
\hline Pai & & & \\
\hline Mãe & & & \\
\hline Irmão & & & \\
\hline Amigos da família & & & \\
\hline
\end{tabular}

Comente:

27. De uma forma geral como vocês avaliam as relações sociais de seu filho:
( ) bom
( ) regular
( ) ruim

28. Seu filho tem dificuldades para enfrentar as novas situações de relacionamento social?

( ) $\operatorname{Sim} \quad$ ( ) Não

Comente:

\section{III - TRATAMENTO REABILITADOR E RECURSOS ORGANIZACIONAIS E COMUNITÁRIOS:}

29. Quando vocês souberam da possibilidade de tratamento no HRAC e quem o informou?

29.1. Época: ( ) antes do nascimento ( ) após o nascimento Espec.
29.2. Informante: ( ) médico
( ) enfermeira
( ) Coordenador
continuação
( ) pac/família
( ) outros Esp.

30. Antes de vinda ao hospital vocês tinham conhecimento sobre a fissura e tratamento?

( ) $\operatorname{sim}$

( ) não

Especifique: 
continuação

31. Vocês procuraram por tratamento em outro local antes da vinda ao HRAC?
( ) $\operatorname{sim}$
( ) não

Especifique:

32. Qual a concepção da família quanto ao tratamento oferecido pelo HRAC:
( ) direito
( ) favor
Comente:

33. Quais as expectativas da família com relação ao tratamento?

( ) estético e/ou cirúrgico ( ) odonto ( )psico ( ) fono ( ) social ( ) outros

Especifique:

34. Vocês conversam com a criança sobre o problema e o prepara para o atendimento
ambulatorial e cirúrgico?
( ) $\operatorname{sim}$
( ) não

Comente

35. Vocês receberam orientações do setor de fonoaudiologia sobre o tratamento necessário a ser realizado na cidade de origem? ( ) sim ( ) não

Comente

36. O paciente realiza tratamento fonoaudiológico na cidade? ( ) $\operatorname{sim}($ ) não

36.1. Qual a periodicidade?

Recomendado

( ) semanal

( ) 2 a 3 vezes/semana

( ) quinzenal

( ) mensal
Realizado

( ) semanal

( ) 2 a 3 vezes/semana

( ) quinzenal

( ) mensal

Comente

36.2. Qual a modalidade do atendimento?
( ) particular
( ) público
( ) convênio
( ) cortesia
( ) outros

Especificar:

36.3. Quem acompanha o paciente nas terapias? ( ) pai ( ) mãe ( ) outros

36.4. Quem tem mais disponibilidade em realizar os exercícios em casa e estimular o paciente no aspecto da fala e da comunicação? ( ) pai ( ) mãe ( ) outros

Comente:

36.5. Quais os recursos utilizados para a viabilização do tratamento fonoaudiológico em sua cidade ou região, nas especificações abaixo: 
continuação

\begin{tabular}{|l|l|l|l|}
\hline & PÚBLICO & PARTICULAR & OUTROS \\
\hline ( ) transporte & & & \\
\hline ( ) hospedagem & & & \\
\hline ( ) alimentação & & & \\
\hline ( ) outros & & & \\
\hline
\end{tabular}

37. Em sua cidade possui:

( ) Carona Amiga ( ) Associação ( ) Núcleo ( ) Sub-sede

( ) Coordenadores ( ) não sei

38. Quais os recursos utilizados para atender aos retornos ao Hospital:
( ) recursos próprios
( ) Carona Amiga
( ) TFD-SUS
( ) outros

Observações:

39. Vocês estão satisfeitos com o tratamento realizado:

no hospital? ( ) $\operatorname{sim}($ ) não

Porque?

continuação $\quad \operatorname{sim}($ ) não

Porque?

Responsável pela entrevista:

Bauru, 
ANEXO 6 - Termo de Consentimento

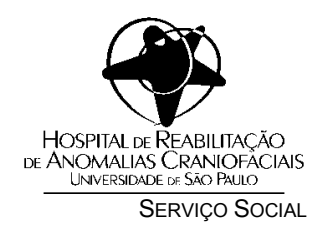

"TERMO DE CONSENTIMENTO LIVRE E ESCLARECIDO"

$\mathrm{Eu}$,

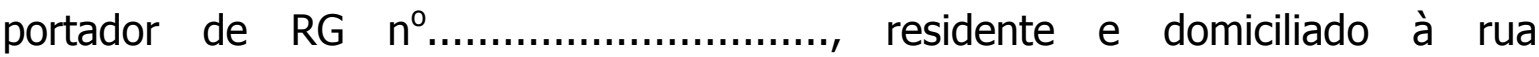
(Av.)

$\mathrm{n}^{\circ}$

na cidade de

Estado

na qualidade de (paciente/responsável)

em tratamento no HRAC com o ${ }^{\circ}$ concordo em participar

da entrevista para coleta de dados da pesquisa: "Aspectos psicossociais e familiares de indivíduos com e sem distúrbios da comunicação decorrentes da fissura labiopalatina", realizada por Regina Célia Meira Garcia CRESS no 6531, sob a orientação da Dra. Maria Inês Gândara Graciano.

A referida pesquisa tem como objetivo geral caracterizar e analisar os aspectos psicossociais culturais e familiares de pessoas com e sem distúrbios da comunição decorrentes da fissura lábio-palatal.

Estou ciente também, de que minha participação é voluntária e dela posso desistir a qualquer momento, sem explicar os motivos e sem comprometer 0 tratamento no HRAC/USP.

Outrossim, tenho conhecimento que será mantido completo sigilo sobre minha identidade e a do profissional que prestou o atendimento, caso queira me identificar como paciente e/ou responsável.

Bauru, 1

Paciente/Responsável

Nome do pesquisador responsável: Regina Célia Meira Garcia

Rua: Silvio Marchione, 3-20

Bauru - SP CEP: $17043-900$ 



\section{ERRATA}

\begin{tabular}{|c|c|c|c|}
\hline PÁGINA & LINHA & ONDE SE LÊ & LEIA-SE \\
\hline $\mathrm{V}$ & 9 & Jennifer & Jeniffer \\
\hline ix e 2 & 10 e 20 & LOAS & LOS \\
\hline ix e 5 & 19 e 9 & Flórida & Florida \\
\hline 6 & 24 & pós tratamento com relação à fala & pós tratamento cirúrgico da fissura com relação à fala \\
\hline 44 & 20 & segundo Souza Freitas & segundo Freitas \\
\hline 49 & 7 & $\begin{array}{l}\text { trabalhadores rurais }(31,3 \%) \text { e trabalhadores } \\
\text { assalariados urbanos }(18,7 \%)\end{array}$ & $\begin{array}{l}\text { trabalhadores rurais assalariados }(35,8 \%) \text {, trabalhadores } \\
\text { assalariados }(28,6 \%) \text { e empregado doméstico urbano } \\
(21,4 \%)\end{array}$ \\
\hline 49 & 22,23 & $\begin{array}{l}\text { nos níveis: colegial incompleto }(50,0 \%) \text { e colegial } \\
\text { completo }(50,0 \%)\end{array}$ & $\begin{array}{l}\text { nos níveis: ginasial incompleto }(50,0 \%) \text {, ginasial completo e } \\
\text { incompleto }(25,0 \% \text { cada })\end{array}$ \\
\hline 50 & 13 & estatística desta categoria & estatística adotando o Teste Qui-Quadrado $\left(x^{2}\right)$ \\
\hline 50 & 14 & $(p=0,064)$ & $(p=0,642)$ \\
\hline 51 & 17 & 73,9 & 73,7 \\
\hline 57 & 14 & culpa do casal $(81,6 \%)$, observamos & culpa do casal, observamos \\
\hline 58 & 16 & sentimento de culpa $(p=0,552)$, não & $\begin{array}{l}\text { sentimento de culpa }(p=0,552) \text {, dificuldade no nascimento } \\
(p=0,515) \text {, causas atribuídas pelos pais }(p=0,326) \text {, não }\end{array}$ \\
\hline 60 & 27 & $(p=0,515)$ & $(p=0,627)$ \\
\hline 64 & 14 & $(p=0,344)$ & $(p=0,572)$ \\
\hline 64 & 14 & atividade de lazer depois & atividade de lazer antes do nascimento $(p=0,344)$ e depois \\
\hline
\end{tabular}




\begin{tabular}{|c|c|c|c|}
\hline 64 & 17 a 21 & $\begin{array}{l}\text { da mãe }(\mathrm{p}=0,019) \text {, o resultado do teste estatístico } \\
\text { demonstrou haver associação estatisticamente } \\
\text { significante nos grupos GI (com distúrbios) e GII (sem } \\
\text { distúrbios), sugerindo esta análise não haver } \\
\text { correlação entre a não inserção profissional da mãe } \\
\text { no mercado de trabalho e desenvolvimento da fala. }\end{array}$ & $\begin{array}{l}\text { da mãe no mercado de trabalho ( }(p=0,019) \text {, o resultado do } \\
\text { teste estatístico demonstrou haver diferença } \\
\text { estatisticamente significante entre os grupos GI (com } \\
\text { distúrbios) e GII (sem distúrbios), ocorrendo maior inserção } \\
\text { das mãe dos pacientes sem distúrbios. }\end{array}$ \\
\hline 68 & 15 & modalidade $(p=0,297) ;$ & modalidade situação escolar $(p=0,297)$; \\
\hline 70 & 30 a 32 & $\begin{array}{l}\text { apelido ( }(p=0,867) \text {; dificuldades de novas relações } \\
(p=0,344) \text { e avaliação geral das relações sociais dos } \\
\text { pacientes pelos pais }(p=0,107) \text { não }\end{array}$ & $\begin{array}{l}\text { apelido }(p=0,867) \text { e dificuldades de novas relações } \\
(p=0,344) \text { não }\end{array}$ \\
\hline 71 & 3 & $(p=0,232)$ & $\begin{array}{l}(p=0,232) \text { e avaliação geral das relações sociais dos } \\
\text { pacientes pelos pais }(p=0,107) \text {. }\end{array}$ \\
\hline 73 & 4 & pais de outros pacientes do HRAC, associações & associações \\
\hline 73 & 30 & da fala $(44,7 \%) \mathrm{e}$ & da fala $(44,7 \%)$, odontológica $(42,1 \%)$ e \\
\hline 74 & 5 & aliançou & alcançou \\
\hline 76 & 12 & $\mathrm{~N}=38$ & $N=32$ \\
\hline 77 & 27 & estatística da categoria & estatística pelo Teste Qui-Quadrado $\left(x^{2}\right)$ na categoria \\
\hline 81 & 25 & e recursos utilizados & $\begin{array}{l}\text { e o Teste Qui-Quadrado }\left(x^{2}\right) \text { na categoria recursos } \\
\text { utilizados }\end{array}$ \\
\hline 86 & 19 & não trabalham foi estatisticamente & não trabalham apresentou diferença estatisticamente \\
\hline 89 & 2 & pós tratamento no & pós tratamento cirúrgico da fissura no \\
\hline 89 & 11 & algumas categorias não apresentassem & a maioria das categorias não apresentou \\
\hline
\end{tabular}

